GARCÍA PALOMINOS, Gonzalo, “(In)compatibilidad del financiamiento ilegal de la actividad parlamentaria con el delito de cohecho (art. 248 y ss. CP).

Polít. crim. Vol. 14, No 27 (Julio 2019), Art. 5, pp. 122-172.

[http://politcrim.com/wp-content/uploads/2019/04/Vol14N27A5.pdf]

\title{
(In)compatibilidad del financiamiento ilegal de la actividad parlamentaria con el delito de cohecho (art. 248 y ss. CP)
}

\section{(In)compatibility of the Illegal Financing of the Parliamentary Activity with the Crime of Bribery (art 248 ss. CP)}

\author{
Dr. Gonzalo García Palominos, L.L. M (Freiburg i.B) \\ Académico del Departamento de Derecho Penal \\ Universidad de los Andes (Chile) \\ ggarcia@uandes.cl
}

\section{Resumen}

Este artículo problematiza la tesis sostenida por organismos públicos de persecución penal de solucionar los posibles vacíos de punibilidad anteriores (y probablemente también, posteriores) a la entrada en vigencia de la Ley $\mathrm{N}^{\circ} 20.900$ sobre financiamiento irregular de la política, utilizando los tipos penales de cohecho de los arts. 248 y ss. del Código Penal. El artículo ofrece una reconstrucción del injusto típico del delito de cohecho (de lege lata), confirmando la opción del legislador por el "modelo del acuerdo ilícito". Se llega a la conclusión que dicho modelo regulatorio es, por regla general, incompatible con la comprensión típica de las constelaciones de financiamiento irregular o ilegal de la política de parlamentarios o congresistas. La solución a aquellos vacíos exigiría una modificación legal que hoy no está contemplada en la legislación chilena.

Palabras clave: Cohecho - parlamentarios - financiamiento ilegal de la política- bien jurídico - acuerdo ilícito- empleado público.

\begin{abstract}
This article examines the thesis of by the Attorney General's Office to solve possible punitive gaps, that have existed before (and probably after) the inforce of Law No. 20.900 on politics' irregular financing, using the criminal offenses of bribery of arts. 248 et seq. of the Criminal Code. The article offers a reconstruction of the crime of bribery (de lege lata), confirming the option of the legislator toward the " illicit agreement model". It is concluded that said regulatory model is, as a general rule, incompatible with the common understanding of irregular or illegal financing constellations of parliamentarian's policy. The solution to those gaps would require a legal modification that is not currently contemplated in Chilean legislation.
\end{abstract}

Keywords: Bribery - parliamentarians - politics' illegal financing - bien jurídico illicit agreement - public employee.

\section{Introducción}

Históricamente, en Chile, no habían existido normas de sanción penal que abarcaran hipótesis relativas al financiamiento irregular de parlamentarios, partidos políticos y campañas políticas de autoridades elegidas por elección popular (alcaldes, gobernadores 
o intendentes, consejeros regionales, parlamentarios y presidentes). Si bien la legislación del financiamiento de Partidos Políticos $\mathrm{N}^{\circ} 19.884$ de $2003^{1}$ incorporó una completa regulación destinada a evitar influencias indebidas que perjudicaran el correcto desarrollo de la democracia, no fue sino hasta la Ley $\mathrm{N}^{\circ} 20.900$ de 2016 que regula el financiamiento de la actividad política, ${ }^{2}$ que se incorporaron figuras delictivas: una hipótesis de otorgación u obtención de aportes irregulares (en exceso de lo permitido o por personas jurídicas) a candidaturas y partidos políticos (art. 27 bis inc. 1 y 2); una hipótesis de ofrecimiento o la solicitud de los aportes (art. 27 bis. inc. 3); una hipótesis de fraude de subvenciones por desviación de fines (respecto del financiamiento público, art. 27 bis inc. 4) y; finalmente otra de presentación de información falsa en rendición de cuenta (art. 27 ter). Ninguna de estas figuras, por lo tanto, estaba destinada a amenazar con pena el ofrecimiento o aceptación de financiamiento a parlamentarios a cambio de una actitud favorable al negocio del financista ni tampoco una figura similar a la de "corrupción de parlamentarios" (compra del voto) existente en países como Alemania (art. 108e $\mathrm{StGB}^{3}$ ). Estas últimas buscan abarcar la "venta del voto", con el objetivo de llenar la laguna existente respecto de las autoridades políticas no cubiertas por la figura clásica del cohecho. Sin perjuicio de lo anterior, dichas figuras tienen la capacidad de solucionar parte de un vacío de punibilidad en un grupo importante de casos $\mathrm{y}$, adicionalmente, diferenciar sustancialmente las hipótesis de financiamiento irregular de la política y las figuras de cohecho (arts. 248 y ss. CP).

En el último tiempo, sin embargo, se han desarrollado persecuciones penales por parte del Ministerio Público en casos caracterizados fácticamente, en esencia, por un sujeto/empresa que ha realizado aportes irregulares a campañas o actividades políticas de parlamentarios, posibilitando una actitud favorable a los intereses de sector a que pertenece en la tramitación de leyes. En principio, la falta de criminalización directa de prácticas de financiamiento irregular de parlamentarios para casos anteriores a la entrada en vigencia de la ley $\mathrm{N}^{\circ} 20.900$ de 2016, ha llevado al Ministerio Público a intentar solucionar dichos vacíos de punibilidad utilizando tipos penales de corrupción clásicos, en especial el delito de cohecho de los artículos 248 y ss. del Código Penal (CP). Para aquello el ente público persecutor ha debido desarrollar una tesis jurídica relativa al delito de "cohecho" que, si bien le permite solucionar aparentemente dichos

\footnotetext{
${ }^{1}$ Modificaciones a esta Ley posteriores a su entrada en vigencia: 18/04/2004, Ley 19.963: Modifica la ley 19.884, sobre transparencia límite y control del gasto electoral, estableciendo sanciones y procedimientos para su aplicación; 06/09/2005, Ley 20.053: Modifica la ley 19.884 sobre transparencia límite y control del gasto electoral; Ley 20.568: regula la inscripción automática, modifica el Servicio Electoral y moderniza el sistema de votaciones; 06/12/2012, Ley 20.640: Establece el sistema de elecciones primarias para la nominación de candidatos a Presidente de la República, Parlamentarios y Alcaldes; 19/06/2013, Ley 20.678: Establece la elección directa de los Consejeros Regionales; 14/04/2016, Ley No 20.900, Para el fortalecimiento y transparencia de la democracia; 27/07/2016, Ley $\mathrm{N}^{\circ} 20.937$ Modifica límites de los aportes propios que efectúan los candidatos a concejal en sus campañas

${ }^{2}$ Véase al respecto TORRES F., Angélica, "Los tipos penales creados por la ley N²0900 para el fortalecimiento de la democracia. Ofrecimiento, otorgamiento, solicitud y obtención indebida de aportes electorales; destinación indebida de aportes electorales estatales; entrega de antecedentes o certificación de hechos falsos al servicio electoral", Revista jurídica del Ministerio Público, $\mathrm{N}^{\circ} 68$, (dic. 2016), pp. 25 y 56 , p. 25 y s.

${ }^{3}$ El $\S 108$ e StGB (Abgeordnetenbestechung o cohecho activo de diputados), es un tipo penal que hace extensible las hipótesis de cohecho activo y pasivo a quien trate de comprar o vender un acto por encargo o por orden.
} 
vacíos pretéritos, también le permitiría solucionar vacíos presentes que se mantienen, aún después de la entrada en vigencia de aquella ley. ${ }^{4}$

La tesis del Ministerio Público tiene una relevancia jurídica penal sustantiva, pues para ello ha asumido ciertos presupuestos diferentes a los desarrollados hasta ahora por la literatura penal. ${ }^{5}$

La tesis se caracteriza por construirse con base en tres pilares fundamentales: primero, la decisión de ampliar el ámbito de protección de la norma penal, de manera de sustituir el objeto positivo de protección (bien jurídico) radicado en el correcto funcionamiento del aparato público por aspectos moralizantes como la integridad, probidad, honestidad o fidelidad del funcionario público; lo anterior se predica de todas las funciones públicas, más allá de la administración pública y de su correcto funcionamiento institucional. Estos principios se verían cristalizados normativamente bajo el concepto de "probidad administrativa", como nueva orientación de las normas de sanción penal. Un segundo pilar de esta tesis es la proposición de una interpretación "omnicomprensiva" del concepto de "funcionario público" del art. $260 \mathrm{CP}$, que, a su vez, es "transferida" directamente a todas las figuras del delito de cohecho, sin consideración de que el injusto pueda exigir vulneración específica de deberes especiales referidos al cumplimiento de ciertas funciones concretas. Se defiende la idea de una especie de "fusión" entre el concepto de funcionario público y el sujeto activo del delito de cohecho. Un tercer pilar se refiere al rechazo radical a la tesis del "acuerdo ilícito", de manera de desarrollar un injusto autónomo en cada figura (activa y pasiva), desligando funcionalmente a la conducta de la contraparte de la interpretación y posibilitando la reconstrucción valorativa de las conductas desde aspectos moralizantes de la función pública. Esto es, deja de exigir una relación entre la posición de deber del cargo y la ventaja indebida que genere una incompatibilidad de deberes, en tanto se refiere al ofrecimiento de ventajas - financiamiento irregular de campañas políticas - sin determinar concretamente su relación con el ejercicio del cargo de parlamentario. Estos tres pilares permitirían construir una nueva tesis: el delito de cohecho como mera infracción a deberes de probidad administrativa.

Este artículo se ha propuesto analizar dicha tesis general y, en particular, contestar las siguientes interrogantes: a) ¿puede el parlamentario ser sujeto activo del delito de cohecho?; b) ¿puede el aporte económico para las campañas a cambio de una "tendencia

\footnotetext{
${ }^{4}$ Se podrían distinguir dos tipos de razones que podría incentivar actualmente al Ministerio Público a mantener, no obstante, la nueva ley $\mathrm{N}^{\circ} 20.900$, la interpretación amplia del delito de cohecho: 1) La mantención de los vacíos en algunas hipótesis y 2) la no comprensión en el art. 1 de la Ley $\mathrm{N}^{\circ} 20.393$ [establece un "numerus clausus"] de delitos de financiamiento irregular de la política que pueden ser vinculados a esta responsabilidad penal de personas jurídicas. En relación a la primera razón (vacíos) piénsese, por ejemplo, en casos de ofrecimiento de un particular de aportes financieros a un candidato que es actualmente parlamentario (incumbente) a cambio de un voto o una actitud favorable a su sector, pero cuyo aporte siendo superior al autorizado por la ley, no excede del $40 \%$ de lo permitido en la Ley $\mathrm{N}^{\circ} 19.884$ (requisito del tipo penal del art. 27 bis inc. 3). También se puede entender como no comprendido por la nueva figura del art. 27 bis similares hipótesis pero que recaen sobre un parlamentario que no es nuevamente candidato y que, adicionalmente, no forma parte de un partido político.

${ }^{5}$ Un estado de la discusión en: OLIVER, Guillermo, "Aproximación al delito de cohecho", Revista de Estudios de la Justicia, № 5 - Año 2004, pp. 83 - 115, passim.; ARTAZA, Osvaldo, "La utilidad del concepto de corrupción de cara a la delimitación de la conducta típica en el delito de cohecho", Polít. crim. Vol. 11, No 21, (Julio 2016), Art. 11, pp. 307 y ss, passim; RODRÍGUEZ COLLAO, José Luis; OSSANDÓN WIDOW, Magdalena, Delitos contra la función pública, Santiago: Editorial Jurídica de Chile, $2^{a}$ ed., 2008, passim
} 
favorable a los intereses del sector" ser abarcado bajo el "acto propio del cargo" o "acto en infracción de los deberes del cargo"? y c) ¿resulta punible el delito de cohecho activo sólo en la medida que se acredite un acuerdo ilícito (más allá de la discusión de la unilateralidad o bilateralidad del delito)? La hipótesis que se demostrará se puede resumir como sigue: sin perjuicio que el cargo de parlamentario - Diputado o Senador pueda estar cubierto limitadamente por el concepto amplio de "empleado público" del art. 260 del CP, sólo estará abarcado por los delitos de cohecho (art. 248 y ss. CP) en la medida que la conducta consista en un acto de deslealtad del funcionario público a algún concreto mandato de representación estatal (administración o ejecutivas). En caso alguno ello se puede producir respecto de la deliberación política, cuyo origen radica en un mandato popular, desarrollada en la votación parlamentaria. Tampoco se trata de un delito de mera infracción de deberes de probidad.

Considerando que el rendimiento de las tesis planteada por el Ministerio Público depende de la toma de posición sobre el modelo de regulación del delito de cohecho (perspectiva teleológica y sistemática) y este, a su vez, depende de la modalidad de conducta y del ámbito de protección, es que este trabajo se estructura, como sigue: (1) Ámbito de protección de la norma penal del cohecho en el ordenamiento jurídico penal chileno; (2) El injusto típico del cohecho y su estructura típica en el Código Penal chileno: modelo del acuerdo ilícito; (3) El concepto de funcionario público y la función legislativa; (4) el acto del empleado público como contrapartida pasiva del cohecho activo del particular y (5) El delito de cohecho y la vulneración de deberes administrativos de probidad de los parlamentarios (perspectiva normativa).

\section{1. Ámbito de protección de la norma penal del Cohecho en el ordenamiento jurídico penal chileno}

Tradicionalmente, y siguiendo la valoración original del legislador y la doctrina internacional, tanto la literatura como la jurisprudencia han identificado como bien jurídico protegido por delito de cohecho al "correcto funcionamiento de la administración pública" o "el funcionamiento de la administración del Estado en base a ciertos valores o principios". El ámbito de protección de la norma penal se centra exclusivamente en la "administración del Estado" y su correcto funcionamiento. ${ }^{6}$ En Alemania y en España ${ }^{7}$, la valoración ha sido similar desde ya hace muchas décadas, y si bien antiguamente se introdujeron aspectos moralizantes (como la "pureza en el desempeño del cargo" ["Lauterkeit des öffentlichen Dientes"] ${ }^{8}$ ), se ha sostenido permanente que el bien jurídico sería "la confianza en la imparcialidad de los funcionarios y en la corrección y objetividad de sus decisiones". 9 Aunque en nuestro

\footnotetext{
${ }^{6}$ Por todos BULLEMORE, Vivian R. ; MACKINNON, John R., Curso de Derecho penal, parte especial, Tomo IV, Santiago, Legal Publishing, p.153; MATUS, Jean Pierre; RAMÍREZ, María Cecilia, Lecciones de derecho penal chileno. Parte especial, tomo II, Santiago: Editorial Jurídica de Chile, $3^{\mathrm{a}}$ ed., 2015, p. 273.

${ }^{7}$ OLIVER, “Aproximación...”, cit. nota n5, pp. 94 y s.

${ }^{8}$ KARGL, Walter, "Über die Bekämpfung des Anscheins der Kriminalität bei der Vorteilsannahme (§ 331 StGB)”, en: Zeitschrift für die gesamte Strafrechtswissentschaft, Bd. 114, 2002, p. 783; HEINE, Günter, "§ 331 ff. StGB”, en: SCHÖNKE/SCHRÖDER, Strafgesetzbuch, Edición 27., Editorial C. H. Beck, München, 2006., nm. 3; (BGHSt 10, 241) o (BT-Drs. 7/550, 269).

9 WELZEL, Hans, "Studien zum System des Strafrechts", en: Zeitschrift für die gesamte Strafrechtswissentschaft, 1939, p. 539; JESCHECK, Hans-Heinrich, "Vorbemerkungen zu § 331 StGB”, en: Leipziger Kommentar, Editorial Walter de Gruyter, Edición 11., Berlín, 1996, nm. 4; SCHMIDHÄUSER, Eberhard, Strafrecht, Besonderer Teil, § 24, J. C. B. Mohr Verlag, Tübingen, 1983,
} 
país también se desarrollaron tesis moralizantes, como la de Labatut que proponía el decoro y el prestigio como bien protegido ${ }^{10}$ o en alguna medida generalizante la de Guzmán Dalbora, ${ }^{11}$ y que ubican a meras normas de probidad (lealtad, integridad, probidad, honestidad, fidelidad) como objeto de valoración positiva protegida por el derecho penal, ellas han sido superadas no sólo por la literatura, sino también por la jurisprudencia de la Corte Suprema. La Segunda Sala de la Exc. Corte Suprema en causa Rol N $\mathrm{N}^{\circ} 97657$ de 4 de diciembre de 2012, en considerando décimo séptimo, citando o haciendo suya la tesis de Oliver, señala: "Identificar como bien jurídico del cohecho los deberes funcionariales es propio de un sistema de tinte claramente autoritario. Los deberes de los empleados públicos no se justifican por sí solos, sino que su existencia obedece a que conducen a la prestación de un servicio para la comunidad...". En otras palabras, según su parecer, dichos deberes no configurarían el bien jurídico del cohecho, sino sólo permitirían que su cumplimiento no afectara el auténtico bien jurídico tutelado por este delito.Esta orientación parece ser adecuada, en tanto permite eliminar propuestas moralistas, idealistas y generalizantes de la lesividad social y, a su vez, obliga a reconstruir adecuadamente el injusto penal.

Sin perjuicio de lo anterior, serán autores vinculados con instituciones encargadas de la persecución penal estatal los que han intentado modificar esa valoración social permanente con el objetivo de solucionar los vacíos de punibilidad antes expuestos, sobre la base de moralizar el contenido del bien jurídico protegido de manera de ampliar las hipótesis de conductas desvaloradas. Contreras Alfaro ha sostenido que el bien jurídico es el correcto ejercicio de la función pública derivada de los fines del Estado de Derecho y el respeto de los funcionarios al principio de la probidad administrativa, lo que se construye desde la relación sistemática de los artículos $1^{\circ}, 6^{\circ}, 7^{\circ}$ y 38 . de la Constitución, en relación con las Leyes $\mathrm{N}^{\circ} 19.653$ y N $\mathrm{N}^{\circ} 19.645 .{ }^{12}$ Del mismo modo, la Fiscalía Nacional del Ministerio Público ha defendido una tesis de carácter formal y moralizante: "el bien jurídico protegido por estas figuras penales (...) será el ejercicio o una relación establecida con una "función pública", de la cual se exige un desempeño recto, probo, ágil y sujeto a las reglas y normas jurídicas por sobre todo". ${ }^{13}$

Edición 2., nm. 1 y ss; DÖLLING, Dieter, "Die Neuregelung der Strafvorschriften gegen Korruption”, en: Zeitschrift für die gesamte Strafrechtswissentschaft, Bd 112, Cuaderno 2, 2000, p. 335.

${ }^{10}$ LABATUT, Gustavo, Derecho Penal, Tomo III, $7^{\text {a }}$ Ed., Editorial Jurídica de Chile, p. 90

${ }^{11}$ GUZMÁN DALBORA, José L., "Esencia y Clase de Cohecho político", en: Cuadernos de Política Criminal, Número 106, I, Época II, abril 2012, pp. 223-250, p. 241: "la integridad de los medios personales en el cumplimiento de funciones públicas", que en el caso son de carácter político. Este autor dice seguir los lineamientos propuestos por NIETO MARTIN (Adán, "El concepto de funcionario público (art. 1)", en: NIETO, Adán /ARROYO, Luis (Coord.), Fraude y Corrupción en el Derecho Penal económico Europeo, Colección Marino Barbero Santos, Ediciones Castilla de la Mancha, 2006, p. 93) que habla - de lege ferenda - sobre el bien jurídico de la "incorruptibilidad" (de parlamentarios), esto es, un objeto de valoración difícilmente de separar metodológicamente del desvalor de la misma acción. El argumento no logra ocultar su tendencia a la moralización generalizada del bien jurídico. Si esta interpretación personal a la propuesta de Guzmán Dalbora es incorrecta, entonces, el problema está radicado en que este autor no distingue el cohecho como una "forma de ataque" que puede afectar a distintos bienes jurídicos (instituciones públicas, privadas, internacionales, etc.), como ya ampliamente se ha aceptado en la doctrina.

${ }^{12}$ Véase CONTRERAS ALFARO, Luis Humberto, "Sobre algunos aspectos penales de la corrupción de funcionarios públicos: La iniciativa del funcionario en el cohecho pasivo", Revista de Derecho, Año 2 $\mathrm{N}^{\mathrm{o}} 1$ (agosto 2001), pp. 169 - 181, passim.

${ }^{13}$ Oficio $N^{\circ}$ 142. Ministerio Público, Fiscalía Nacional. Instructivo general $N^{\circ} 10$ sobre la investigación de los delitos cometidos por empleados públicos en el desempeño de sus cargos. Santiago, 12 de octubre de 2000 . 
La moralización de la dogmática del cohecho ha encontrado un aliado adicional en la tendencia a la idealización y generalización de la teoría de los bienes jurídicos y la dañosidad social, ${ }^{14}$ en especial, en aquella que identifica como bien protegido la "confianza en la función pública" o la confianza en la probidad de la función o en cierto ethos ministerial o de la administración. Esta orientación se afirma en explicaciones criminológicas que exponen la dañosidad social sólo desde perspectivas macrosociales. La literatura criminológica alemana, ${ }^{15}$ por ejemplo, ha intentado probar que la corrupción no solo daña el funcionamiento de las instituciones públicas sino también la confianza en ellas, ${ }^{16}$ lo que se concretaría por medio de fenómenos sociales que la criminología denomina: reacción en cadena ("Ya que todos lo hacen"), los llamados "efecto succión" y "efecto espiral". ${ }^{17}$ La lesividad social así considerada no es consecuencia, por lo tanto, sólo de un efecto sumatorio o acumulativo, sino "multiplicador" (efecto expansión o imitador). ${ }^{18}$ Esta perspectiva, le ha permitido a la literatura penal, explicar la dañosidad no sólo de las hipótesis clásicas de cohecho, sino también de todo tipo de conductas contrarias a la probidad y a la ética pública, en tanto tendrían - por vulnerar las expectativas políticas de la ciudadanía - la capacidad de mancillar la confianza pública en las instituciones del Estado. Asimismo, le permite construir figuras de cohecho desvinculadas de la concreta disfuncionalidad en el ámbito de la administración pública. Conocido ha sido el debate en Alemania en torno al parágrafo 332 StGB (CP) y la propuesta de Schröder - al menos lo que dudosamente la literatura entiende de ésta - de explicar que las meras infracciones de deberes (de mera apariencia de venalidad) produciría un peligro para la confianza, permitiendo así la renuncia al requisito de infracción del cargo (desviación funciones) propio del delito de cohecho. ${ }^{19}$ Sin perjuicio de lo anterior, la reconstrucción de la desvalaroración de las conductas de cohecho como injusto penal desde dicha perspectiva macrosocial (como fenómeno criminológico), pierde su capacidad para explicar la lesividad social desde la conducta individual, en tanto debe asociar la conducta individual con fenómenos "macrosociales" para ser desvalorada y, de ahí, debe renunciar a la construcción de un derecho penal a partir de una imputación individual.

La moderna explicación teórica sobre el bien jurídico del cohecho, por el contrario, encuentra su desarrollo embrionario, en gran parte, en las opiniones de Welzel. ${ }^{20}$ Este

\footnotetext{
${ }^{14}$ Véase en extenso GARCIA PALOMINOS, Gonzalo, "La idealización y la administrativización de la punibilidad del uso de Información Privilegiada: Un análisis de los discursos penales en la doctrina chilena", en: Polit. Crim, Santiago v. 10, n. 19, jul. 2015, pp. 119-158, passim

${ }^{15}$ VAHLENKAMP, Werner/ KNAUSS, Ina, Korruption - hinnehmen oder handeln?, Bundeskriminalamt, Forschungserie, 1995, pp. 125 y ss.

${ }^{16}$ VAHLENKAMP/KNAUß, Korruption, cit. nota $\mathrm{n}^{\circ} 15$, p. 125 (126 y ss.).

17 BANNENBERG, Britta, Korruption in Deutschland und ihre strafrechtliche Kontrolle, Bundeskriminalamt (BKA) Kriminalistisches Institut, Hermann Luchterhand Verlag GmbH, 2002, p. 50.

${ }^{18}$ DÖLLING, "Die Neuregelung...", cit. nota ${ }^{\circ} 9$, nm. 38

19 LOOS, Fritz, "Zum „Rechtsgut" der Bestechungsdelikte ", en: STRATENWERTH, Günter; KAUFMANN; Armin; GEILEN, Gerd; HIRSCH, Hans J., SCHREIBER, Hans-Ludwig; JAKOBS, Günther y LOOS, Fritz (Eds.), Festschrift für Hanz Welzel, Berlin, New York: Editorial Walter de Gruyer, 1974, 879-895, p. 888. (Hay traducción de este texto realizada por Jose Luis Guzmán Dalbora: LOOS, Fritz, "Del „bien jurídico“ en los delitos de cohecho”, en: Zeitschrift für Internationale

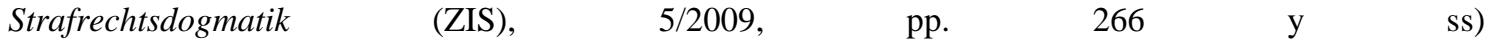
https://www.unifr.ch/ddp1/derechopenal/obrasportales/op_20090603 01.pdf [Visitado el 02.02.2018].

${ }^{20}$ Véase evolución en profundidad en la obra de AMELUNG, Knut, Rechtsgüterschutz und Schutz der Gesellschaft, Frankfurt a. M., 1972.; GARCIA PALOMINOS, Gonzalo, "Del paradigma de la dañosidad social centrado en la infracción normativa al paradigma metodológico centrado en la norma de sanción: un falso dilema", en: BLANCO, R.; IRURETA, P. IRURETA (Eds.) Justicia, Derecho y Sociedad, Libro
} 
autor, sin perjuicio de acentuar que los bienes jurídicos son protegidos indirectamente por normas, ${ }^{21}$ no deja de concebir al bien jurídico - y, de ahí, su análisis sobre el "merecimiento de protección penal" - en atención "a la función que el objeto de protección pueda cumplir para la vida social": "In-Funktion-Sein". ${ }^{22}$ Con dicha orientación propone identificar funciones concretas que provean un servicio al ciudadano. Aquello, permitiría entender, por ejemplo, que el bien jurídico protegido por el delito de cohecho sería la confianza en la integridad de la administración pública, pero concebida institucionalmente como la garantía al ciudadano de que, al interactuar con un servidor público, este no será "comprable" y no falsificará la "voluntad de los órganos del Estado". ${ }^{23}$ Esta tesis mayoritaria parte del presupuesto que los funcionarios públicos reciben del Estado un mandato de desarrollar funciones de administración en su nombre, las que están asociadas a la interacción con el ciudadano (que se encuentra cristalizados en deberes).

En la actualidad se puede advertir en la literatura penal, de manera relevante, el desarrollo de dos aspectos acentuados en relación a la valoración social: ${ }^{24}$ aspectos internos y aspectos externos. ${ }^{25}$ Los aspectos internos dicen relación con las condiciones de funcionamiento de las instituciones de la administración del Estado; esto es, con aspectos relativos a los procesos de decisión o administración de las distintas instituciones públicas: ${ }^{26}$ en primer lugar, entonces, se ubicaría la capacidad de funcionamiento y de garantización de la gestión pública de los fines institucionales o intereses $^{27} \mathrm{o}$ "la legalidad formal y material del ámbito externo de funcionamiento de los servicios públicos", ${ }^{28}$ la "objetividad y legalidad de la actividad de los empleados públicos", ${ }^{29}$ " "la objetividad (en consideración a la posición funcional en el Estado: corrección) en dirección de determinados funcionarios públicos". ${ }^{30}$ En segundo lugar, se acentúa la llamada condición de funcionamiento externa (aspecto externo); esto es, el funcionamiento macroinstitucional, relacionado con la confianza de la ciudadanía en el correcto funcionamiento de la administración pública y en los aspectos de probidad de

en Memoria de Maximiliano Prado D., Santiago: Ediciones Universidad Alberto Hurtado, 2014, pp. 143196, passim.

${ }^{21}$ WELZEL, Hans, Das Deutsche Strafrecht, Berlin: Walter de Gruyter Verlag, 11. Ed., 1969, p. 2 y ss.

22 WELZEL, "Studien ...", cit. nota n9, pp. 515 ss.

23 WELZEL, "Studien ...", cit. nota n9, p. 539.

${ }^{24}$ El bien jurídico de los $\S \S 331$ LOOS, "Zum 'Rechtsgut'...", cit. nota n¹9, p. 879 y ss; SCHWIEGER, Dirk, Der Vorteilsbegriff in den Bestechungsdelikten des StGB, Peter Lang Verlag, Bd. 25, Frankfurt a. M., 1996 p. 91; HEFENDEHL, Roland, Kollektive Rechtsgüter im Strafrecht, Köln: Carl Heymanns Verlag KG, 2002, p. 322; SATZGER, Helmut, "Bestechungsdelikte und Sponsoring", en: Zeitschrift für die gesamte Strafrechtswissentschaft, Bd. 115, Cuaderno 4, 2003, pp. 469-500, p. 473; KORTE, Matthias, "Kommentar $\S \S 331$ StGB”, en: Münchener Kommentar, Strafgesetzbuch, Bd. 4, C. H. Beck, München 2006, nm. 8; TRÖNDLE, Herbert/ FISCHER, Thomas, "Vorbemerkungen zu $§ 331$ und Kommentar $\S 331$ ff. StGB", en: Tröndle/Fischer, Strafgesetzbuch und Nebengesetze, C. H. Beck, 54 Ed. München, 2007, nm. 3.

${ }^{25}$ Véase LOOS, “Zum 'Rechtsgut'...”, cit. nota n`19, pp. 885 y ss y 889 y s.; HEFENDEHL, Kollektive, cit. nota $\mathrm{n}^{\circ} 24$, p. 322.

${ }^{26}$ RUDOLPHI, Hans- Joachim/ STEIN, Ulrich, "Vorbemerkungen $\S 331$ StGB und Kommentar $\S 331 \mathrm{ff}$. StGB”, en: Systematischer Kommertar zum Strafgesetzbuch, Bd. II, 58. Lfg., 6. ed., Luchterhand Verlag, September 2003, nm. 7a.

${ }^{27}$ LOOS, “Zum 'Rechtsgut'...", cit. nota n¹9, pp. 879 y ss.

${ }^{28}$ GRIBL, Kurt, Der Vorteilsbegriff bei den Bestechungsdelikten, C. F. Müller, Heidelberg, 1993, p. 77.

${ }^{29}$ HEFENDEHL, Kollektive, cit. nota ${ }^{\circ} 24$, p. 322.

${ }^{30}$ SCHWIEGER, Dirk, Der Vorteilsbegriff in den Bestechungsdelikten des StGB, Peter Lang Verlag, Bd. 25, Frankfurt a. M., 1996, p. 91. 
la misma. ${ }^{31}$ Sin perjuicio del reconocimiento de ambos aspectos en la discusión "política criminal", en la discusión dogmática sobre la reconstrucción y la configuración del injusto - de manera de no vulnerar el principio ex iniuria tertii (por la perspectiva acumulativa que exigiría) ${ }^{32}$ - se construye sólo desde la perspectiva microinstitucional que implica idoneidad para afectar funciones concretas.

En conclusión, más allá de los discursos dogmáticos orientados a la moralización de la actividad pública y de los intentos por vincular la conducta individual del cohecho con condiciones sociales del funcionamiento macroinstitucional o el ethos seguido por instituciones públicas (acudiendo a una idealización de la lesividad de la conducta y a explicaciones acumulativas del injusto, repetido de muchas personas), lo claro es que la dogmática penal nacional e internacional ha entendido que el ámbito de protección de este tipo de normas penales está radicado en el concreto "funcionamiento de la administración del Estado". Esta capacidad de funcionamiento institucional, se trata de aquél garantizado por el correcto cumplimiento de los deberes funcionariales sobre los cuales se configuran los cargos públicos, de manera leal al mandato estatal. Por lo mismo, este bien puede recibir ataques desde adentro (deslealtad del funcionario público) o desde afuera (búsqueda del privado de promover o incentivar tal deslealtad), afectando las expectativas de los ciudadanos creadas y diseñadas en torno a la funcionalidad de sus sistemas. Sin perjuicio de lo anterior, la mera infracción de deberes funcionariales que vinculan al empleado público y Estado son incapaces, por si solos, para manifestar todo el injusto del delito de cohecho. La relevancia jurídico penal de la infracción a deberes del cargo son aquellos que mantienen una relación de funcionalidad con el bien jurídico. ${ }^{33} \mathrm{El}$ deber relevante penalmente, es aquél que - como señala correctamente De la Mata B.- constituye un presupuesto instrumental de protección del verdadero interés jurídico-penal, la función que desarrolla en beneficio de los administrados. $^{34}$

En nuestro país, la moderna doctrina ha optado precisamente por esta perspectiva microinstitucional. Oliver, ${ }^{35}$ por ejemplo, adopta una perspectiva orientada al contacto del Estado con los "ciudadanos" y específicamente al "correcto servicio que la Administración presta a los ciudadanos."; mientras que Rodríguez Collao reconstruye

31 Véase LOOS, "Zum 'Rechtsgut'...", cit. nota n 19 , pp. 885 y ss, p. 889 y s.; HEFENDEHL, p. 322; RUDOLPHI/STEIN, "Vorbemerkungen § 331 StGB...", nm. 7 y ss.

${ }^{32}$ Con mayor detalle en relación a este problema véase GARCIA PALOMINOS, Gonzalo, "Equivalentes funcionales en los delitos económicos. Una aproximación de solución ante la falta de lesividad material en delitos de presentación de información falsa al mercado de valores", en: Polít. crim. Vol. 12, $\mathrm{N}^{\mathrm{o}} 23$ (Julio 2017), Art. 6, pp. 177-206, pp. 175 y ss.

${ }^{33}$ En el mismo sentido véase DE LA MATA BARRANCO, Norberto, "El bien jurídico protegido en el delito de cohecho. La necesidad de definir el interés merecedor y necesitado de tutela en cada una de las conductas típicas encuadradas en lo que se conoce, demasiado genéricamente, como ámbito de la corrupción, en: Revista de Derecho Penal y Criminología, 2.a Época, N 17 (2006), pp. 81-152, pp. 96. y SS.

${ }^{34}$ DE LA MATA BARRANCO, "El bien jurídico protegido...”, cit. nota n³3, p. 98.

${ }^{35}$ OLIVER, “Aproximación...", cit. nota n5, pp. 95 y s.

${ }^{36}$ RODRÍGUEZ COLLAO, José Luis, "Delimitación del concepto penal de corrupción", en: Revista de Derecho de la Pontificia Universidad Católica de Valparaíso, XXV (Valparaíso, Chile, 2004), pp. 339359, p. 332 (p. 357: En el ámbito jurídico penal, lo que realmente interesa -en atención a los fines que persigue este sector del ordenamiento jurídico- es la protección de los derechos de las personas y el aseguramiento de las condiciones básicas para que éstas se desarrollen en el plano espiritual y material. Para ello el individuo se transforma en destinatario de una serie de prestaciones que implican la actuación 
el ámbito protegido desde las distintas funciones que cumplen los funcionarios y que permiten configurar distintos bienes jurídicos (decisión conforme a legalidad; actuación conforme a un fin determinado; observancia de la objetividad; preservación de la imparcialidad; coordinación jerárquica en aras de la eficacia; actuación conforme a garantías procedimentales, etc.). Interesante resulta la descripción de la lesividad que Oliver expone, orientada a la funcionalidad concreta de la organización: “(...) si el empleado solicita o acepta un beneficio económico, en caso de prestaciones gratuitas, o mayores derechos que los debidos, en caso de prestaciones remuneradas, para ejecutar un acto propio de su cargo, ya habrá impedido que el servicio llamado a prestar se brinde de manera correcta." ${ }^{37}$ Politoff/Matus/Ramírez, de la misma forma, entiende el recto funcionamiento de la Administración Pública, como aquel que logran los funcionarios por medio del cumplimiento del deber especial concreto frente a la consecución de sus finalidades en orden a la prosecución del bien común. ${ }^{38}$

Dos conclusiones deben ser consideradas, para los efectos de los objetivos propuestos en este trabajo. Primero: la doctrina moderna y la jurisprudencia mayoritaria entienden como objeto de la modalidad de ataque, en las hipótesis de cohecho de los arts. 248 y ss, a las diversas instituciones de la Administración de Estado. Esto es, aquella organización pública que, para cumplir sus funciones públicas (diseño, gestión y ejecución de políticas públicas y representación estatal), requiere delegar tareas ejecutivas y de representación en agentes de la institución, esto es, funcionarios o empleados públicos; segundo: mirado ya sea desde la perspectiva prestacional que permite adoptar tanto el concepto de confianza institucional en el funcionamiento de la administración estatal (y su correlativa expectativa institucional) o derechamente del neutro "Correcto funcionamiento de la administración" como bien jurídico, lo claro es que la protección institucional está vinculada con los intereses directos de los ciudadanos. No se trata, entonces, de la mera vulneración de normas funcionariales o de probidad que afectan el funcionamiento, sino de aquellas sobre las cuales se configura el funcionamiento de la administración y que permite que el ciudadano interactúe con el Estado de modo objetivo. ${ }^{39}$

Si el cohecho es una modalidad de ataque a las instituciones que, en términos normativos, involucran a los sujetos encargados del cumplimiento funcional para la cual fueron estas diseñadas, la determinación de aquel objeto fija el tipo de institución protegida específicamente por la norma. Desde esta perspectiva, entonces, se identifica un primer conflicto entre las conclusiones de este trabajo con la tesis del Ministerio Público y defendida dogmáticamente (aunque de lege ferenda) por autores como Guzmán Dalbora. ${ }^{40}$ Los parlamentarios, por regla general, no diseñan, gestionan ni ejecutan políticas públicas delegadas funcionalmente y cuyo funcionamiento adecuado dependa de sus "actos del cargo" o el "cumplimiento de sus deberes". Tampoco, por regla general, los parlamentarios tienen deberes de realizar actos de los que dependan funciones que garanticen expectativas que le permitan al ciudadano relacionarse con el

de un conjunto de entes cuya actividad se orienta, precisamente, a la satisfacción de aquellas necesidades y que, de acuerdo con un terminología bastante difundida, se denomina como interés general o interés de la colectividad".

${ }^{37}$ OLIVER, “Aproximación...”, cit. nota n5, pp. 95 y s.

${ }^{38}$ POLITOFF, Sergio/ MATUS A., Jean P./ RAMÍREZ, María Cecilia Ramirez, Lecciones de Derecho Penal chileno. Parte Especial, Editorial Jurídica de Chile, Santiago, 2003, p. 487.

${ }^{39}$ DE LA MATA BARRANCO, "El bien jurídico protegido...", cit. nota n³3, p. 105 y s.

${ }^{40}$ GUZMÁN DALBORA, "Cohecho político...", cit. nota $n^{\circ} 11$, p. 241 
Estado (exigencia asociada al bien jurídico como confianza institucional). Sólo excepcionalmente es posible identificar aspectos que pueden ser comprendidos.

\section{El injusto típico del cohecho y su estructura típica en el Código Penal chileno: modelo del acuerdo ilícito}

Otra de las discusiones esenciales de la dogmática del delito de cohecho es la referida al modo conductual denominado "cohecho" como forma especial de ataque institucional, discusión que, si bien está vinculada, sobrepasa la desarrollada en torno al bien jurídico y la dañosidad social. Ni a nivel internacional, ni entre nosotros en Chile, la cuestión es pacífica. La mayor complejidad se ha producido debido a que no cualquier acto de corrupción configura el injusto del cohecho. Dos modelos se enfrentan: aquél que pone el acento en la ilicitud moral del sujeto activo y que abriría las puertas a concebir como cohecho cualquier conducta violatoria a los deberes de probidad. Este modelo aceptaría como comprendido por el injusto típico aquellas constelaciones caracterizadas por la mera infracción a deberes de probidad, sin exigir que el acto ejecutado u omitido por el funcionario implique desviación de funciones que tengan la idoneidad de afectar el bien jurídico. ${ }^{41}$ Un segundo modelo, "del acuerdo ilícito", explica el desvalor de la conducta tanto en la venta de la función pública - expresada en un acuerdo ilícito o en la orientación objetiva o subjetiva a este - como en la deslealtad funcionarial contra los intereses del mandante - en este caso el Estado - con efectos funcionales de este último. ${ }^{42}$ Estos últimos pueden expresarse - como lo defiende la dogmática alemanacomo un "falseamiento de la voluntad estatal". ¿Cuál modelo sigue el Código Penal chileno y qué efecto tiene en esta clase de imputación del Ministerio Público? ¿Existe coherencia entre el bien jurídico identificado por la literatura y el modelo de regulación chileno?

\subsection{El modelo chileno}

El Código Penal chileno acoge distintos grupos de delitos de cohecho en el ámbito de la administración de Estado que se configuran por la combinación de elementos incorporados en el tipo penal de cohecho del empleado público (arts. 248, 248 bis y 249 CP) y del particular (art. 250). De aquella combinación de factores es posible distinguir, desde un punto de vista temporal, hipótesis de cohecho antecedente (para ejecuta/omitir) y subsiguiente (por haber ejecutado/omitido) y; desde el punto de vista conductual, figuras vinculadas con la ejecución de actos o conductas (ej. ejecutar un acto con infracción a los deberes de su cargo) y de omisión de deberes o conductas (haber omitido este un acto debido propio de su cargo). Cada una de ellas recibe una desvaloración independiente, aunque vinculada estructuralmente con las demás.

La literatura nacional ha entendido que estas distintas figuras del delito de cohecho del art. 248 y ss. CP se construyen sobre la base de un "núcleo conductual", esto es, de una constelación fáctica de encuentro común que le da sentido al ilícito "independizado" del

\footnotetext{
${ }^{41}$ Véase en Alemania SCHRÖDER, Horst, "Das Rechtsgut der Bestechungsdelikte und Bestechlichkeit des Ermessensbeamten”, en: Goltdammer's Archiv für Strafrecht (GA) 1961, pp. 269 y 298, passim.

${ }^{42}$ Una discusión similar en el ámbito anglosajón véase en GREEN, Stuart, Mentir; hacer trampas y apropiarse de lo ajeno, Una teoría moral de los delitos de cuello blanco, Madrid, Barcelona, Buenos Aires, Sao Paulo: Marcial Pons, 2013, p. 271 y ss.

${ }^{43}$ Véase en extenso LOOS, “Zum 'Rechtsgut'...", cit. nota n 19 , pp. 880 y ss.
} 
cohecho activo y pasivo, esto es: orientación al acuerdo ilícito. ${ }^{44}$ Este marcará, no obstante su actual estructura de consumación autónoma, el sentido y la orientación de la interpretación de sus elementos e hipótesis. ${ }^{45}$ En efecto, si bien cada una de las figuras del cohecho - del funcionario y la del particular - se construyen independientemente por haber sido divididas (atrofiadas) para efectos de criminalizar ámbitos de la tentativa como consumación (tipos de emprendimiento o Unternehmensdelikte) ${ }^{46}$ - sin que se exija que se haya aceptado o cerrado el acuerdo ilícito - el legislador de todas formas construye dichas figuras de manera vinculada: agrega como exigencia típica que la conducta de solicitud u ofrecimiento y de aceptación o consentimiento tenga por objeto (para o por) la correlativa prestación o contraprestación. ${ }^{47}$ En efecto, las figuras están construidas de forma simétrica y coherente, de tal manera que el particular (art. $250 \mathrm{CP}$ ) que consiente en dar un beneficio económico, necesariamente debe haber recibido de parte del funcionario público, aun cuando el tipo penal no lo exija expresamente, una solicitud con ese objeto y el ofrecimiento de un acto propio del cargo en infracción de deberes (art. 248 bis CP); la misma relación simétrica se produce con la figura del cohecho pasivo del funcionario público que sólo se puede comprender - que acepte recibir (art. $248 \mathrm{CP}$ ) - si antes un particular ha ofrecido un beneficio económico a cambio de una función pública concreta (art. $250 \mathrm{CP}$ ).

Si bien es cierto que la nueva estructura coloca el antiguo ámbito de la tentativa en estado de consumación (también llamado delito de emprendimiento), el Ministerio Público no reconoce en la estructura típica el hecho de tratarse de "un delito atrofiado de dos actos", en que la aceptación o el consentimiento de la contraparte son recortados y son reemplazados por otro elemento objetivo o subjetivo; en este caso, por la exigencia de que el objeto de la solicitud/ofrecimiento sea el negocio completo: prestación (beneficio) y contraprestación "para ejecutar/omitir o para que realice". En otras palabras el injusto del cohecho pasivo/activo incluye, en un nuevo elemento mixto (objetivo/subjetivo), aquella parte de la constelación desvalorada que ha sido recortada al dividir el acuerdo ilícito, pero sin eliminarla por completo; ya que exige que esta conducta deba estar orientada a promover la conducta del sobornado con un objeto con contenido específico, esto es, la correlativa prestación/contraprestación ilícita. Aquello, sin duda, ofrece un rendimiento dogmático importante en la interpretación de las distintas figuras del cohecho, como se verá más adelante. Además, esta tesis mayoritaria tiene el rendimiento de que la acentuación del "acuerdo ilícito", como base de las distintas figuras de cohecho, permite delimitar los

\footnotetext{
${ }^{44}$ La moción parlamentaria que dio origen a la Ley N 19645 de 1999 sostenía que "Es necesario terminar con el carácter bilateral del delito, esto es, no puede mantenerse como requisito del mismo el que se produzca concurso de voluntades entre el empleado público que pide una coima y el particular que acepta pagarla; o al revés, entre el particular que ofrece una coima y el empleado público que admite recibirla. En cambio, debe sancionarse como delito de cohecho tanto la conducta del empleado público que pide una coima, aunque su petición no sea aceptada, como la del particular que la ofrece, aunque su oferta sea rechazada por el funcionario." (Fecha 12 de abril, 1994. Moción Parlamentaria en Sesión 10. Legislatura 328).

45 Así, por ejemplo, en la literatura alemana OTTO, Harro, Grundkurs Strafrecht, Allgemeine Strafrechtslehre, 7. Aufl., Walter de Gruyter, Berlin, 2004, § 99, nm. 14.

${ }^{46}$ MITSCH, Wolfgang, "Das Unternehmensdelikt", en: Juristische Ausbildung (JURA), 34(7), 2002, pp. 526-530, passim; JAKOBS, Günther, Strafrecht, Allgemeiner Teil: Die Grundlagen und die Zurechnungslehre, De Gruyter Verlag, 1993, Libro II. Capítulo 5, Ab. 25, nm. 5 y ss.

${ }^{47}$ De la misma forma es acentuada por MAÑALICH, Juan Pablo, "La negociación incompatible como delito de corrupción: estructura típica y criterios de imputación”, en: Revista de Estudios de la Justicia (REJ), No 23, Año 2015, pp. 93-105, p. 95.
} 
delitos de los arts. 248 y ss. de otros grupos de delitos de corrupción, como la exacción ilegal o la negociación incompatible. ${ }^{48}$

El riesgo de una interpretación del cohecho activo totalmente independiente del "complejo desvalorado en su conjunto" (esto es, que no comprenda el acuerdo ilícito ni siquiera como metáfora ${ }^{49}$ ), radica principalmente en una incapacidad de comprender el injusto fundado en la incompatibilidad de intereses entre la ventaja ofrecida/solicitada y la posición de deber del funcionario público; un aislamiento de las figuras activas y pasivas podría significar que la mera infracción de deberes sea entendido como ilícito penal lo que, si bien puede resultar una desvaloración legítima para el legislador, no es legítima para el aplicador del derecho de "lege lata". Por ejemplo, que la entrega de un beneficio económico para campañas políticas pueda ser comprendida como conducta típica, aun cuando no tenga por objeto un acuerdo de intercambio de ventajas económicas/funcionariales, resulta ser dudosa. ${ }^{50}$ En otras palabras, sin perjuicio de los nuevos diseños de las figuras típicas - por razones de facilitación de la persecución o la prueba - la propuesta de desconocer la orientación hacia el acuerdo ilícito resulta ser contraria a la misma ley.

La tesis del Ministerio Público acá problematizada, no es absolutamente coincidente con la historia de nuestro precepto que, en este punto se aparta de la regulación desarrollada en el Código Penal español, como se ha encargado de demostrar entre nosotros Hernández. ${ }^{51}$ La decisión de la Comisión Redactora del Código Penal chileno ${ }^{52}$ apartándose de dicha regulación que sancionaba la mera obtención de regalos, aunque no necesariamente de la idea de contraprestación - se construyó como "infringir el deber por dinero, ejecutando actos que le están prohibidos" o "hacer u omitir por dadiva o promesa algún acto propio de su cargo", esto es, basándose en una idea de "acuerdo ilícito" que, como contraprestación, exige del otro un ilícito. Aquella orientación exigía, por ejemplo, en palabras de Etcheberry, no sólo la recepción del regalo, sino adicionalmente una "relación directa con la ejecución u omisión de un acto obligatorio" o de Labatut de "que la dadiva o promesa tenga por objeto que el funcionario ejecute un acto justo o injusto de su función". ${ }^{53}$ Esa tesis se ha mantenido luego de las reformas legales, aunque a modo de orientación. En efecto, correctamente Hernández ha sostenido que la actual regulación del cohecho en Chile exige que la conducta del agente en cuestión esté precisamente enderezada a la conclusión de un cierto "acuerdo ilícito" más o menos sinalagmático, en el que una parte aporta un acto funcionario. Así, y si bien en su configuración típica actual no es necesario para la consumación - un acuerdo de voluntades - de igual forma expresa su verdadero desvalor si está dirigida a este, por constituir su objeto de referencia obligatorio. ${ }^{54}$

\footnotetext{
${ }^{48}$ MAÑALICH, "Negociación”, cit. nota n47, p. 96

${ }^{49}$ La idea de "metáfora contractual" es utilizada por MAÑALICH, "Negociación", cit. nota n47, p. 94.

${ }^{50}$ KINDHÄUSER, Urs, "Presupuestos de la corrupción punible en el Estado, la economía y la sociedad. Los delitos de corrupción en el Código Penal alemán”. Polít. crim. no 3, 2007, A1, p.7.

${ }^{51}$ Con mayor desarrollo en HERNANDEZ, Héctor, "La inconveniente exigencia de un acto funcionario determinado como contraprestación en el delito de cohecho", en: Revista de Ciencias Penales Sexta época, Vol. XLIII, N 4, 2016, pp. 15-27, p. 17.

${ }^{52}$ Véase Sesión $N^{\circ} 52$ del 4 de agosto de 1871, en: Actas de las Sesiones de la Comisión Redactora del Código Penal Chileno, Imprenta de la República, 1873, pp. 102 y ss.

53 ETCHEBERRY, Alfredo, Derecho penal. Parte especial, $3^{\circ}$ edición, Editorial Jurídica de Chile, Santiago 1998, T. IV, p. 256.

${ }^{54}$ HERNANDEZ, "La inconveniente...", cit. nota n ${ }^{\circ}$ 1, p. 15 y ss.
} 
La decisión del legislador chileno por entender que la conducta prohibida consistente en los binomios solicitar/aceptar u ofrecer/consentir un negocio - cuyo objeto es la prestación y contraprestación - implica la disposición del funcionario público sobre la ejecución de la función pública que, a su vez, representa una desvaloración de la conducta por constituir un abuso de los poderes decisorios en una forma contraria a la voluntad o los intereses del Estado. El funcionario prioriza, en este diseño, sin autorización, intereses secundarios o privados por sobre los del Estado. ${ }^{55}$ Este modelo de regulación encuentra su explicación material en la dogmática, ya sea desde explicaciones fenomenológicas de la corrupción o teleológicas desde la dañosidad social.

Una de estas explicaciones a esta forma de entender el injusto del cohecho y la estructura de los tipos penales - y que explica la intención del legislador por conservar el contenido esencial del injusto - se comprende acudiendo al desarrollo dogmático de Kindhäuser desde el concepto de corrupción como una especial forma de "una determinada forma de agresión" institucional. Señala que dicha conducta puede entenderse como un acto de corrupción (cohecho) sólo en la medida que reúnan ciertas características fenomenológicas, ya que bajo dicho concepto no se abarcan todos los tipos de ataque a las instituciones: 1) como elemento esencial de la corrupción, la recompensa debe estar referida a una especial posición de deber en favor de otro (sujeto facultado para tomar decisiones) y 2) la ventaja debe ir en contra del interés en el correcto ejercicio de la actuación funcionarial. En otras palabras, debe existir una relación entre la posición de deber y la ventaja indebida que genere una incompatibilidad de deberes. ${ }^{56}$ Este autor examina una serie de constelaciones que, en particular, constituyen otorgación de ventajas al funcionario público pero que, o no implican una referencia a la posición del sujeto o no van en contra de los intereses del correcto ejercicio de la actuación funcionarial, lo que demostraría que la pérdida de la contextualización de la ilicitud del acuerdo, puede generar una confusión de proporciones. Como acentúa Artaza, en relación con la posición del Kindhäuser, lo característico sería el abuso de los poderes decisorios en una forma contraria a los intereses que debieran ser considerados como primordiales (los del representado), debido a una priorización no autorizada de intereses secundarios (los del representante actuando como privado). ${ }^{57}$ Un análisis semejante en nuestro país es emprendido por Artaza $^{58}$ y, mucho antes, había propuesto Rodríguez Collao ${ }^{59}$. Este último, entiende que todos los tipos penales asociados a la corrupción deben ser entendidos como una especie de incompatibilidad entre los intereses privados y públicos; por lo mismo, acoge la conceptualización de Comisión Nacional de Ética, en que la característica de las conductas corruptas es la "desviación de las obligaciones normales que incluye una función pública y la violación de las normas legales que la regulan, con el propósito de satisfacer un interés privado (...)" ${ }^{60}$

La opción del legislador y de la literatura nacional por el modelo del acuerdo ilícito incluso luego de haberse fraccionado las figuras y diseñado como indepedientes - tiene efectos relevantes en la interpretación de los tipos penales de cohecho. Aquello es consecuencia de que el injusto del delito de cohecho, si bien no se manifiesta por medio de

\footnotetext{
${ }_{55}^{55}$ ARTAZA, "La utilidad del concepto...", cit. nota n5, p. 316.

${ }^{56}$ KINDHÄUSER, "Presupuestos...", cit. nota n50, p. 6.

${ }^{57}$ ARTAZA, "La utilidad del concepto...", cit. nota $n^{\circ} 5$, p. 316.

${ }^{58}$ ARTAZA, "La utilidad del concepto...," cit. nota $\mathrm{n}^{\circ} 5$.

${ }^{59}$ RODRÍGUEZ COLLAO, José Luis, "Delimitación...", cit. nota n³6, pp. 339 y ss.

${ }^{60}$ RODRÍGUEZ COLLAO, "Delimitación...", cit. nota n³6, p. 357 y s.
} 
la exigencia del acuerdo ilícito efectivamente producido (como consumación), sí lo hace por la sustitución de la conducta de la contraparte por la inclusión de un elemento adicional, referido al objeto del acuerdo ilícito.

Efecto 1: El delito de cohecho activo o pasivo se caracteriza, siguiendo la ilustrativa definición de Nino, por desvalorar una "conducta de quien ejerce una cierta función social que implica determinadas obligaciones activas o pasivas destinadas a satisfacer ciertos fines, para cuya consecución fue designado en esa función, y no cumple con aquellas obligaciones o no las cumple de forma de satisfacer esos fines, de modo de obtener un cierto beneficio para él o un tercero, así como también la conducta del tercero que lo induce o se beneficia con tal incumplimiento". 61 Independiente, entonces, de la técnica legislativa utilizada por el legislador, el soborno y cohecho sólo pueden expresar su injusto desde la idea de contraprestación. ${ }^{62}$

La estructura contractual ilícita estaría, como se destaca en la literatura alemana ${ }^{63}$ y anglosajona $^{64}$, configurada por tres sujetos: 1) el Estado que gartantiza institucionalmente el interés público; 2) el empleado público que representa los intereses estatales, que debe ejecutar las políticas públicas en interés general y que debe representar al Estado frente a terceros y 3) el particular que se relaciona con el Estado. Los actos de corrupción - como el cohecho - son especiales actos de deslealtad del empleado público frente a su deber de representación del Estado tanto a) en la representación del interés general como b) en su facultad de representación del Estado frente a terceros. ${ }^{65}$ De ahí que el injusto en el delito de cohecho en la administración estatal sea descrito como la comercialización de la función pública, que se caracteriza por la otorgación de dos tipos de ventajas: un beneficio económico con atención a la posición funcionarial (por parte del particular) y un acto fucionarial desviado del interés general o la omisión de un acto funcionarial neutro (como contraprestación del funcionario público), en favor de un interés particular. ${ }^{66}$

Efecto 2: En el caso de la regulación chilena se trata, entonces, de un delito fraccionado de dos actos, que se caracteriza porque la conducta del sujeto activo debe ir dirigida a incentivar otra conducta, con base en un incentivo económico o la recepción de un privilegio público. Si bien no es exigida la conducta de la contraparte para la consumación, desde una perspectiva objetiva, sí constituye una exigencia típica la determinación del objeto de la oferta/solicitud que manifiesta el acuerdo ilícito completo. En el caso particular de estos delitos de cohecho activo del particular o del funcionario, no se trata de preparar las circunstancias que permiten una segunda conducta del mismo sujeto activo, sino la de un tercero (particular o funcionario público) que actúa con su propio injusto doloso: la aceptación o el consentimiento "para o por". Aquello exige, naturalmente, no sólo que el sujeto activo reconozca en su conducta de ofrecimiento (del particular) o en una solicitud (del funcionario público) un exceso de aquello que puede otorgar o recibir, sino "esencialmente" que la conducta típica tenga como objetivo incitar un acto posterior con un contenido ilícito (deslealtad de la representación del Estado, por desviación de fines u

\footnotetext{
${ }^{61}$ NINO, C., Un país al margen de la ley, $1^{\circ}$ edición, Ariel, Buenos Aires, 2005, p. 109

${ }^{62}$ HERNANDEZ, "La inconveniente...", cit. nota ${ }^{\circ} 51$, p. 3.

${ }^{63}$ KINDHÄUSER, "Presupuestos...", cit. nota $n^{\circ} 50$, p.7.

${ }^{64}$ Véase GREEN, Mentir, cit. nota n ${ }^{\circ} 42$, p. 268 y ss.

${ }^{65}$ Véase KINDHÄUSER, "Presupuestos...", cit. nota n50, p. 7.

66 Sobre el aspecto "trilateral" del acuerdo ilícito, véase KINDHÄUSER, "Presupuestos...", cit. nota n'50, p. 7; ARTAZA, "La utilidad del concepto...", cit. nota n5, p. 318; GREEN, Mentir, cit. nota n42, p. 258.
} 
omisión). Por lo mismo, debe ser comunicativamente apta o idónea ex ante para provocar "la conducta posterior de aceptación o consentimiento para".

Adicionalmente, el ofrecimiento/solicitud debe ser de carácter condicional [si y sólo si/ do ut des (te doy para que me des)], esto es, se ofrece una prestación a cambio de una contraprestación, de manera tal que las meras liberalidades no se encuentran cubiertas. Así ya lo ha sostenido, entre nosotros, la Sentencia de la Corte de Apelaciones de Antofagasta Rol 370-2010 del 12 de diciembre de 2010, en que se consideró que la mera liberalidad y práctica de dar propina a los sepultureros de un cementerio no constituye la retribución de alguna circunstancia especial.

Efecto 3: El objeto del cohecho activo del particular (ofrecer) o del funcionario público (solicitar) tendrá siempre como contrapartida una conducta del funcionario público o del particular que manifieste absolutamente la contracara "injusta" del acuerdo ilícito; esto es, el cohecho activo sólo podrá demostrar su verdadero contenido de injusto si el objeto concreto de su oferta o solicitud está radicado en una conducta también representativa de la contracara de su "injusto", eliminando cualquiera interpretación objetiva o neutra. Así, por ejemplo, no sería aceptable que la contracara de ofrecer una dadiva fuera el mero ejercicio del cargo o funciones en un sentido correcto o acto que constituye su propia obligación (aquello es propio del modelo español no basado en el acuerdo ilícito ${ }^{67}$ ) y, por el contrario, sólo lo podrá ser una actuación funcionarial desleal a la función estatal, esto es, en contra del interés que debe resguardar el titular del cargo sea por la vía de la ejecución de una acción o una omisión. Sólo así, la conducta típica podrá demostrar su verdadero contenido de injusto y exigir la incompatibilidad de intereses entre la ventaja ofrecida u obtenida y la posición de deber del funcionario público. ${ }^{68}$

\subsection{El modelo de "cohecho" del proyecto de ley (Boletín $\left.\mathrm{N}^{\circ} 10.739\right)$ : “en razón del cargo"}

En los días que se termina de escribir este artículo, se discute en el Congreso Nacional la posibilidad de reformar la figura del cohecho del funcionario público del art. $248 \mathrm{CP}$. En su último trámite, y de manera sorpresiva, el ejecutivo propuso modificar la figura base del delito de cohecho del funcionario público, como una forma de simplificar la prueba de estos delitos, cercenando el elemento subjetivo trascendente del tipo penal que definía el objeto

\footnotetext{
${ }^{67} \mathrm{Al}$ respecto véase HERNANDEZ, "La inconveniente...", cit. nota n51, p. 18.

${ }^{68}$ Así lo ha sostenido el Ministerio Público, por ejemplo, en el Recurso de Nulidad presentado en el caso Kodama, al alegar, según se expresa en el mismo fallo (Vistos $2^{\circ}$ ): “(...) respecto de los artículos 248 bis y 250 del Código Penal ya que el sentenciador exigió requisitos que son propios del agotamiento del delito y no de su configuración, olvidando que se trata de delitos de emprendimiento que se completan con el solo hecho de solicitar o aceptar dádiva para los fines señalados por la ley, lo anterior es aplicable a ambos tipos penales no siendo requisito el beneficio económico entregado ni la infracción de deberes realizada para la comisión del delito en grado de consumado; (...) “; También en sentencia de Corte Suprema del 04/12/2012, considerando décimo octavo, se presenta de manera difusa esta tesis, en tanto, sólo exige un ofrecimiento de un beneficio económico, sin que se destaque que el objeto del mismo no es una mera liberalidad - una donación o un regalo - sino de un intercambio de prestación/contraprestación y no una mera conducta neutra: "no se requiere que el funcionario reciba algo del particular para que su comportamiento se considere típico, sino que basta que admita lo que el particular le ofrece. En lo que dice relación con los derechos que están señalados por razón del cargo del empleado, cabe incluir aquí todos los casos en que los funcionarios están facultados para cobrar una suma de dinero por el servicio que prestan al público. Así ocurre, por ejemplo, con los notarios, los conservadores, los archiveros y los receptores. Estos funcionarios sólo pueden cobrar los montos establecidos en sus respectivos aranceles, incurriendo en delito de cohecho si solicitan o simplemente aceptan sumas superiores", véase SCS del 04/12/2012, considerando décimo octavo, cita online: CL/JUR/2764/2012.
} 
de la solicitud del funcionario público (solicitar y aceptar). ${ }^{69}$ Aquella modificación muta el delito desde una conducta "vinculada subjetivamente a un concreto acto del funcionario que manifieste su deslealtad institucional" a una especie de "coaptación" genérica del funcionario que represente aquella deslealtad: "en razón del cargo". Aquella simplificación del tipo penal, sin embargo, podría entenderse de dos formas diferentes: i) como una simplificación del tipo penal, esto es, como un adelantamiento de la punibilidad o penalización de la tentativa pero manteniendo la idea del acuerdo ilícito o; ii) como una modificación del modelo regulatorio del cohecho al de una mera infracción moral lesiva para el prestigio y confiabilidad de la institución, lo que se expresa en una concepción del cohecho sin la idea de deslealtad a la institución, de la misma forma como algunos autores se refieren al modelo español o alemán ${ }^{70}$. Aquella posibilidad interpretativa corre el riesgo de que, junto con simplificar el tipo penal para efectos probatorios, termine por diluir el significado social y material del concepto de "cohecho".

Schünemann, refiriéndose a la regulación alemana, propone un análisis teleológico desde el bien jurídico para solucionar esta clase de problemas, de manera similar al que se emprende en este artículo, y demostrar que no es suficiente para la configuración del injusto con una mera liberalidad vinculada con la posición en el cargo público [como la entrega de un obsequio en consideración a la posición] y, por el contrario, se requiere una relación entre ella y el ejercicio del cargo. Desde esta perspectiva sostiene que si lo protegido es la confianza en la integridad del servicio público o, en particular, en la objetividad e imparcialidad de la administración pública, aquello significa que el funcionario público debe orientar su conducta, ya no desde los principios que rigen la organización, sino a su propio beneficio, por lo que resulta ser insuficiente la obtención de una mera regalía o liberalidad. ${ }^{71}$ La exigencia típica "para el ejercicio del cargo" ("für die Diestausübung"), y que tendría la misma significación de la propuesta en Chile "en razón del cargo", no sólo exige una "relación con el ejercicio del cargo", sino más bien, una relación sinalagmática, no en el sentido civil, sino en el sentido de una relación de contrapartida (Gegenseitingkeitsverhältnis) entre la ventaja u obsequio y el ejercicio del cargo. ${ }^{72}$ Por cierto, aquello significaría atender y reconocer que en la vida social existen casos en que se entregan beneficios, pero no "para el ejercicio del cargo", sino por motivos distintos. Militello - en busca de aquella expresión de deslealtad propia del acuerdo ilícito - entiende que esta figura desvalora específicamente que el funcionario público se ponga a disposición del corruptor "para cualquiera eventualidad en que se pudiere tener necesidad de su intervención". 73

Vázquez- Portomeñe, por su parte, sostiene que, ya que estas figuras se asientan sobre la base de la desvinculación del beneficio y la realización u omisión de un acto

\footnotetext{
69 “Artículo 248.- El empleado público que en razón de su cargo solicitare o aceptare un beneficio económico o de otra naturaleza al que no tiene derecho para sí o para un tercero, será sancionado con la pena de reclusión menor en su grado medio, inhabilitación absoluta para cargos u oficios públicos temporal en su grado mínimo y multa del tanto del beneficio solicitado o aceptado. Si el beneficio fuere de naturaleza distinta a la económica, la multa será de veinticinco a doscientos cincuenta unidades tributarias mensuales."

${ }^{70}$ HERNANDEZ, “La inconveniente...”, cit. nota n51, p. 18.

71 SCHÜNEMANN, Bernd, "Die Unrechtsvereinbarung als Kern der Bestechungsdelikte nach dem KorrBekG”, en: DANNECKER, Gerhard (Coord.) Festschrift für Harro Otto, Köln, München, 2007, 777-798, p. 787.

72 SCHÜNEMANN, “Die Unrechtsvereinbarung...”, cit nota ${ }^{\circ} 61$, p. 791.

${ }^{73}$ MILLITELLO, Vicenzo, "Concusión y cohecho de los funcionarios públicos”, en: Terradillos Basoco, Juan M./ Acale, María, Temas de Derecho Penal Económico, Editorial Trotta, 2004, 241-266, p. 246.
} 
funcionarial, es que su relación con el bien jurídico "función pública" sólo podrá explicarse desde la idoneidad lesiva o "progresión criminal". Esto es, como un peligro abstracto en relación a la legalidad o imparcialidad de los actos administrativos. Con el objetivo de acentuar la contradicción de intereses propia del cohecho, y distinguirla de otras influencias espurias, propone que el beneficio se provea en un contexto que explique aquella potencialidad o peligrosidad objetiva: i) el funcionario tiene capacidad para interferir en asuntos que pudieran afectar al particular y ii) que se hallen pendientes de resolución en el momento de la admisión del regalo. Desde la perspectiva subjetiva exige que el funcionario asuma la posibilidad de ser destinatario de futuras peticiones o solicitudes relativas al ejercicio de su cargo, en el ámbito concreto de actividad al que se refiere, excluyendo las constelaciones de "donaciones incongruentes" (meras liberalidades) o la concesión de premios por jurados imparciales o casos de Anfüttern o tanteos de la corruptibilidad de funcionarios. Estos últimos casos sólo serían abarcados - de una manera que puedan fundamentar una imputación penal - en la medida que sea reconocible para el funcionario "lo que persigue el donante", esto es, conseguir favores en forma de actuaciones o decisiones del cargo). ${ }^{74}$

\section{El concepto de "empleado" público en el delito de cohecho y su compatibilidad limitada con la función legislativa}

\subsection{Concepto de "empleado público" en el art. 260 CP.}

Todas las hipótesis de los artículos 248 y ss. CP exigen que el objeto de la oferta o de la solicitud (cohecho activo) constituya un acto de un funcionario público titular de deberes específicos de un "cargo público". Lo anterior, como se ha dicho, es consecuencia de que el desvalor de la conducta está radicado en la comercialización de la función en la gestión de los intereses del Estado de la que un sujeto es titular. De ahí que el concepto de "empleado público" del art. $260 \mathrm{CP}$, para los efectos de este Título y del Párrafo IV del Título III, se incorpora en los tipos penales de cohecho directamente, exigiendo nuestra revisión respecto a la intensidad de esta.

Como ya se ha adelantado, un pilar en la tesis del Ministerio Público es la fusión identidad material - del concepto de funcionario del art. $260 \mathrm{CP}$ con las exigencias típicas de los arts. 248 y ss. CP. Se amplía el ámbito de aplicación del tipo penal con la falta de autonomía de la infracción al deber propio del cohecho y el amplio contenido material del concepto del art. 260. Esta tesis no sólo ha quedado plasmada permanentemente en los casos en que el Ministerio Público ha emprendido persecución penal, sino también en los Oficios $\mathrm{N}^{\circ} 142$ de 2000 y No 551 de 2003 de la Fiscalía Nacional del Ministerio Público. Mientras el primero utiliza el concepto amplio del art. 260 CP para determinar directamente el sujeto activo del delito de cohecho (o el sujeto de la oferta) sin mayores correcciones ulteriores, el segundo oficio adecúa - y amplía asistemáticamente - el concepto a la necesidad de acoger las exigencias de ciertos instrumentos internacionales. ${ }^{75}$ La tesis tiene algún antecedente importante en la

\footnotetext{
${ }^{74}$ VÁZQUEZ- PORTOMEÑE, "El delito de admisión de beneficios en consideración al cargo y la prevención de la corrupción pública en Bolivia", en: Rev. boliv. de derecho, $\mathrm{N}^{\circ} 22$, julio 2016, ISSN: 2070-8157, 121-157, p. 132 y ss. (p. 134)

${ }^{75}$ Convención Interamericana contra la Corrupción; la Convención Interamericana contra la Corrupción (Caracas, el 29 de marzo de 1996 y promulgada por Decreto Supremo R.R.E.E. №1879, de 1998); la convención para combatir el Cohecho a Funcionarios Extranjeros en Transacciones Comerciales
} 
jurisprudencia nacional en tanto se ha aceptado que la calidad de empleado público exigida por el tipo de cohecho se presenta al cumplir un sujeto "una función pública para un órgano del Estado", en términos generales, sin hacer mención a la naturaleza del mandato de algunas de las funciones específicas exigidas en el delito de cohecho (Sentencia Corte Suprema Rol N².321-07 de 19 de mayo de 2008 y replicada en causa Rol N ${ }^{\circ}$ 25.378-2.014 de 28 de junio de 2016). En adelante se demostrará - desde una perspectiva, gramatical, histórica y sistemática - que la simplificación de la tesis del Ministerio Público resulta ser incorrecta, en tanto puede llegar a abarcar más hipótesis de lo que el injusto del cohecho admite.

El art. 260 del CP diseña el concepto de "empleado público" para ser aplicado en un amplio grupo de delitos del Título V del Libro II (De los crímenes y simples delitos cometidos por empleados públicos en el desempeño de sus cargos) y del Párrafo IV del Título III (De la tortura, otros tratos crueles, inhumanos degradantes, y de otros agravios inferidos por funcionarios públicos a los derechos garantidos por la Constitución). Se trata de un extenso grupo de delitos, todos los cuales están vinculados con la función pública "interna" a la administración estatal nacional, que exigen como sujeto activo del delito una persona que detente una "posición especial en la administración, gestión pública o ejecución de políticas públicas en la administración del Estado" (gestión de intereses del Estado), independiente del poder del Estado de que se trate y del origen del cargo o función. ${ }^{76}$ Así, por ejemplo, en un extremo se encuentra el delito de "apremios ilegítimos", que puede ser cometido por un empleado público que, desde el punto de vista de las obligaciones internacionales, debe entenderse en sentido amplio, como un agente del Estado. En el otro extremo, de los delitos funcionarios, la desvaloración de sus conductas no se entiende si alguno de ellos no responde a la lógica de ser sujetos ubicados en una posición especial en la administración del Estado, o titular de deberes específicos en la gestión pública o que no posean una vinculación de representación (mandato) funcional para con la administración del Estado y que no sea controlable por Estado. Piénsese en los delitos del título V. ${ }^{77}$

El art. 260 del CP incluye, adicionalmente, la frase "No obstará a esta calificación el que el cargo sea de elección popular" que incorpora a sujetos titulares de cargos públicos que, sin perjuicio de la fuente de su poder público, representan un mandato estatal de ejecutar una política pública, como la que realiza o implementa, a modo de ejemplo, un alcalde. Esta interpretación "amplia" del art. $260 \mathrm{CP}$, y extendida al delito de cohecho, ha llevado a entender como abarcados los parlamentarios no sólo en sus labores administrativas, de gobierno o investigativas - todas manifestaciones de un

\footnotetext{
Internacionales de la OCDE (suscrita el 17 de Diciembre de 1997 y promulgada por D. S. N 496 de 10 de Octubre de 2001) y la Convención de las Naciones Unidas en contra de la Corrupción.

${ }^{76}$ ARANCIBIA, Jaime "Concepto de Empleado Público Administrativo en el art. 260 del Código Penal, en: Arancibia, Jaime/Martínez, José I. (Coord.), La Primacía de la Persona, Estudios en Homenaje al Profesor Eduardo Soto Kloss, LegalPublishing, 2009, pp. 961 - 971, p. 961.

77 Art. 256. El empleado público del orden administrativo que maliciosamente retardare o negare a los particulares (...); Art. 255. El empleado público que, desempeñando un acto del servicio, cometiere cualquier vejación injusta (...); "Art. $254 \mathrm{El}$ empleado que sin renunciar su destino lo abandonare (...); Art. 253. El empleado público del orden civil o militar que requerido por autoridad competente, no prestare, en el ejercicio de su ministerio (...); Art. 252. El empleado público que se negare abiertamente a obedecer las órdenes de sus superiores en asuntos del servicio (...); Art. 247 bis. El empleado público que, haciendo uso de un secreto o información concreta reservada (...); Art. 239. El empleado público que en las operaciones en que interviniere por razón de su cargo, defraudare o consintiere que se defraude al Estado (...)
} 
mandato estatal en sentido amplio -, sino también incluso en las políticas y legislativas [propias de un mandato popular]. Así lo sostuvo, aunque para otros efectos, la Corte Suprema en la causa Rol N ${ }^{\circ}$ 2.321-07. "c/ Carlos Cruz Lorenzen y otros ${ }^{78}$ y directamente en causa Rol N ${ }^{\circ}$ 9779-10 "c/ Jorge Sabag Villalobos", de 20 de abril de 2011, considerando $12^{\circ}$. Por su parte, la literatura nacional ha sido relativamente parca en el análisis, restringiéndose al aspecto gramatical y, en parte, al estudio histórico, sin ahondar en su contenido desde una perspectiva sistemática y teleológica. Posiblemente, el único trabajo más intenso es la memoria de prueba de Bunster que sostuvo que el concepto del art. $260 \mathrm{CP}$ comprendía a todos los sujetos que desarrollan alguna actividad en la administración pública y esta, a su vez, debía entenderse en sentido amplio como "entera actividad del Estado" incluida la labor legislativa, en tanto constituye un ejercicio de responsabilidades y deberes. ${ }^{79}$ De manera menos sustantiva, pero siguiendo la tesis desarrollada por el primero, autores como Labatut o Etcheberry destacan que lo relevante es la vinculación de carácter funcional permanente o transitorio con el Estado, de las que no escaparía las administrativas, municipales o judiciales (en el caso de Labatut) ${ }^{80}$ y que agregan las funciones generales del poder legislativo (en el caso de Etcheberry).

Sin perjuicio de las propuestas anteriores, el concepto de "empleado público" no constituye un constructo omnicomprensivo, sino sólo uno amplio que permite al legislador, por medio de este mecanismo de remisión normativa sintética, adecuarse a las distintas hipótesis delictivas en las que el Código Penal desvalorará una conducta de un sujeto vinculado funcionalmente con la Administración del Estado y su gestión pública. La posibilidad de abarcar como "empleados públicos" a concejales o alcaldes, cuyo origen es una elección popular, se basa en el hecho de que parte importante de sus funciones - aunque no todas - sean administrativas y ejecutivas. Por tanto, se rigen por criterios establecidos y funciones definidas por ley y, además, mantienen una relación de subordinación a aspectos de la Administración del Estado o a la Gestión Pública. ${ }^{82}$ La situación de los parlamentarios, a diferencia de la de alcaldes y concejales, es diversa en tanto ellos no sólo ejercen potestades derivadas de un mandato estatal de carácter administrativo [ejemplo, administrar recursos en la gestión de oficina parlamentaria y asesores], sino esencialmente otras de carácter de representación popular, por ejemplo, legislar o emitir opiniones políticas. Así las cosas, si bien el concepto de "empleado

\footnotetext{
78 “CUADRAGÉSIMO SEXTO.- (...) Así sucede con los parlamentarios, encargados inequívocamente de "funciones públicas" en órganos de creación estatal, según el amplio alcance que a esta noción atribuye el actual artículo $8^{\circ}$ de la propia Carta Fundamental, sin que la circunstancia de ser los primeros elegibles por votación popular, altere esta conclusión, por expresa formulación en tal sentido en el acápite final del artículo 260, analizado."

${ }^{79}$ BUNSTER BRICEÑO, Álvaro (1948) La malversación de caudales públicos: Estudio de Doctrina y Jurisprudencia, Santiago de Chile: Universidad de Chile (Memoria de Licenciatura), p. 29.

${ }^{80}$ LABATUT, Gustavo, Derecho Penal, Tomo II, $7^{\text {a }}$ edición, Editorial Jurídica de Chile, 2000, p. 37.

${ }^{81}$ ETCHEBERRY, Derecho penal, cit. nota n`53, p. 204 y s.

82 En este sentido general: Exc. Corte Suprema (en: Revista de Derecho y Jurisprudencia, Tomo LXIII No 2, 1966, sección IV, p. 84.): "Aunque el legislador no ha definido en forma expresa el concepto de "cargo público" diversos preceptos legales y la interpretación de la ley que autoriza el artículo 21 del Código Civil, permiten concluir que un cargo es público, en oposición a la actividad privada, cuando vincula al empleado con las actividades del Estado o de otras corporaciones o entidades destinadas a satisfacer fundamentalmente necesidades públicas, en otras palabras, organismos de carácter permanente cuya finalidad es la satisfacción de tales necesidades de una manera regular y continua y es evidente que las municipalidades, dados los fines que la Constitución Política del Estado y su ley orgánica les señalan participan de esas características".
} 
público" podría abarcar el cargo de parlamentario, es dudoso que lo haga en toda su dimensión.

Un ámbito de ampliación distinto, pero que tiene la capacidad de generar una confusión innecesaria sobre el contenido material o sustantivo del concepto del art. $260 \mathrm{CP}-\mathrm{y}$ hace más urgente una distinción entre su contenido y los deberes funcionariales de los delitos en particular - radica en las últimas modificaciones legales que parecen ampliar asistemáticamente el concepto. Una de aquellas modificaciones se refiere a la incorporación del cohecho de funcionarios públicos extranjeros en el art. 251 bis CP., pero que, sin embargo, recibió una rápida solución por el legislador. Se incluyó un artículo 251 ter $\mathrm{CP}$ que desarrolló, en atención al ámbito de protección diferente de la norma, un concepto ad hoc de funcionario público internacional, sin que aquello generara un problema sistemático con las demás figuras. La otra modificación con capacidad de generar confusión es la del art. 4 de la Ley $\mathrm{N}^{\circ} 20.393$, que establece la Responsabilidad Penal de Personas Jurídicas. Esta señala expresamente "c) Se entenderá que las personas naturales que participan en las actividades de certificación realizadas por las entidades señaladas en la letra anterior cumplen una función pública en los términos del artículo 260 del Código Penal.”. Esta inclusión da la impresión de que sujetos que no ejecutan funciones estatales, pero sí de fe pública - y quizás ampliable a otras funciones sociales - podrían estar siendo abarcadas no sólo por la definición del art. $260 \mathrm{CP}$, sino que además por el ámbito de protección y aplicación de los tipos penales de los arts. 248 y ss. CP. Aquello, sin embargo, es incorrecto. Esto, porque el "certificador" de programas de cumplimiento, si bien puede cumplir una función de fe pública, no ejerce deberes en la administración de algunos de los poderes del Estado que puedan ser compatibles luego con el delito de cohecho, por no ejecutar un mandato estatal. La necesidad de aclarar la relación entre el art. 260 CP y 248 y ss. $\mathrm{CP}$ se vuelve necesaria, aunque ya la historia del precepto permite una primera aproximación.

De un análisis primario de carácter histórico, se puede evidenciar una cierta tendencia de omnicomprensión del concepto. Lo anterior es consecuencia - como señala Arancibia Mattar - de haber sido diseñado en un contexto histórico de transición del modelo de regulación indiano al modelo borbónico en que la función pública no es ordenada sólo según la ley, sino esencialmente según las labores de servicio a la comunidad que el sujeto realice. ${ }^{83}$ En efecto, el art. $260 \mathrm{CP}$ tiene como origen el Código Penal de 1874 que fue tomado casi íntegramente del art. 331 del CP español de 1848 («todo el que desempeña un cargo público, aunque no sea de Real nombramiento ni reciba sueldo del Estado») ${ }^{84}$ Como comenta Pacheco, ${ }^{85}$ la expresión empleado público ha sido entendida como un concepto que abarca a toda persona que tiene un carácter en la sociedad, "dirigido a su ordenación según la Ley". De ahí que el concepto no sólo comprendía a funcionarios del orden civil que prestan funciones por nombramiento del gobierno en la administración del Estado, sino también a otros sujetos como un alcalde elegido por elección popular, el escribano que ha heredado su oficio o el cura que obtuvo en oposición su curato. Lo relevante, por lo tanto, no era el origen sino la condición de prestar una función pública que deba ordenarse según la ley. El legislador

83 Véase ampliamente en ARANCIBIA, “Concepto de Empleado Público...”, cit. nota n79, p. 961, p. 961.

${ }^{84}$ ARANCIBIA, “Concepto de Empleado Público...”, cit. nota n79, p. 961.

${ }^{85}$ PACHECO, Joaquín Francisco, El Código Penal. Concordado y Comentado., $2^{\text {a }}$ Edición, V. II, Madrid, 1856, p. 393. 
chileno de 1874 al incorporar dicho art. 260 al nuevo Código Penal intentó lograr un efecto similar al original. ${ }^{86}$ Sintomático de aquello es que la principal discusión relativa a este artículo, tanto en la comisión de redacción como en el parlamento, giró en torno a si aquella extensión funcional podría abarcar a eclesiásticos, esto es, a particulares que ejercían excepcionalmente funciones públicas. Dicho artículo en su origen, entonces, respondió a una necesidad estructural relativa a los servicios públicos y las instituciones públicas e, incluso, privadas que las desarrollaban, en tanto todas ellas eran titulares de una "función" portadora de deberes que servían para diseñar los tipos penales del "título i del párrafo IV del título tercero" (original). ${ }^{87}$

Con posterioridad, sin embargo, el concepto recibiría influencias externas determinantes, principalmente por la modificación institucional que significó el fenómeno de separación de iglesia y Estado, en que la administración central del Estado y la burocracia asumirían prácticamente todas las funciones de servicio a la comunidad, adquiriendo el concepto un sentido esencialmente estatal. ${ }^{88}$ La necesidad de extensión funcional, sólo pasó a tener algún sentido avanzado el siglo XX en el ámbito de las funciones públicas y administrativas desarrolladas por organismos o entes públicos descentralizados, autónomos o sometidos a un régimen jurídico privado, incluso, a particulares concesionarios de servicios públicos. Todo lo anterior, fue reconocido por la permanente jurisprudencia penal de nuestro país. ${ }^{89}$ Las extensiones a particulares resultan ser más bien una excepción, como la que realizó el legislador chileno el año 2009 , por medio del art. 4 letra c) de la Ley $\mathrm{N}^{\circ} 20.393$, en que señala que las personas naturales que participan en las actividades de certificación de programas de cumplimiento relacionada con la responsabilidad de personas jurídicas cumplen una función pública en los términos del art. 260 CP.

Quizás uno de los problemas más significativos que tuvo que sortear el concepto estuvo radicado en los constantes dictámenes de la Contraloría General de la República - por ejemplo, los $\mathrm{N}^{\circ} 64.215$, de 1961, y 11.307, de 1969, - que definiendo el concepto "funcionario público" limitó de manera formal el de "cargo" utilizado en la definición del primero, afectando su concepción penal. En este contexto se explica la principal modificación del art. $260 \mathrm{CP}$, a través del artículo 29 de la ley $\mathrm{N}^{\circ} 15.078$, de 1962, que pretendía volver al concepto amplio y funcional original. Respeto del primer punto, la última redacción se caracterizó por un interés distinto al que tuvieron los legisladores originales en 1874. Sustantivamente, por esta vía, el legislador aclaró tres aspectos: 1) modificó la definición, intercambiando el concepto limitado de "cargo" asumido por la

\footnotetext{
${ }^{86}$ El art. 251 del Proyecto de CP y art. 263 durante la discusión en el parlamento señalaba: "Para los efectos de este título i del párrafo IV del título tercero, se reputa empleado todo el que desempeña un cargo público, aunque no sea de nombramiento del Jefe de la República, ni reciba sueldo del Estado".

87 FERNANDEZ, Pedro Javier, Código Penal de la República de Chile, esplicado y concordado, $2^{\mathrm{a}}$ Edición, Tomo I, 1899, p. 413.

${ }^{88}$ Véase en extenso ARANCIBIA, “Concepto de Empleado Público...”, cit. nota n79, p. 963.

${ }^{89}$ Véase ARANCIBIA, "Concepto de Empleado Público...", cit. nota n79, p. 963:. C. Suprema, 6 enero 1923. G. 1923, 1er sem., No 38, p. 340; C. Suprema, Santiago, 22 noviembre 1947. G. 1947, $2^{\circ}$ sem., N 68, p. 390; C. Suprema, 20 agosto 1935. G. 1935, 2ºm., No 78, p. 240; C. Suprema, 5 noviembre 1958. R., t. LXI, $2^{\text {a }}$ parte, sec. $4^{\text {a }}$, p. 187; La sentencia Corte Suprema en Revista Fallos del Mes $\mathrm{N}^{\circ} 42$, mayo 1962: "Aunque el Estatuto Orgánico de una empresa dependiente de CORFO señale que sus empleados estarán sometidos a las disposiciones del Código del Trabajo y sus leyes complementarias, debe tenerse presente que tal determinación obedece a fines administrativos y de orden previsional y que ella en ningún caso puede marginar a todos los empleados de las responsabilidades por los delitos que cometen en el desempeño de sus cargos públicos o interés colectivo".
} 
cultura jurídica ("se reputa empleado todo el que desempeña un cargo") por los conceptos "cargo o función" (se reputa empleado todo el que desempeñe un cargo o función pública), para distinguir la vinculación a la administración del Estado de carácter formal y de carácter funcional $;{ }^{90}$ 2) el legislador señaló ámbitos en que la administración del Estado por vía directa (Administración Central, municipales, autónomas u organismos creados por el Estado o dependientes de él) o indirecta - por vía de delegación del ejercicio de facultades - (instituciones o empresas semifiscales) desarrollan tareas o funciones, como ha señalado Arancibia, que representan la "primera línea de la administración del Estado"; 91 3) decidió aclarar que debido a que ciertas autoridades elegidas por elección popular, pero que ejercen labores ejecutivas y administrativas - de la misma forma que las desarrolladas por los ejemplos anteriores debían ser abarcadas por el concepto. Aquella limitación quedó, además, debidamente establecida en la discusión de la Ley N 19.645 de $1999 .{ }^{92}$

En conclusión, si bien no cabe duda de que autoridades elegidas por elección popular como pueden ser los alcaldes, concejales, parlamentarios, etc. - pueden ser abarcadas por la conceptualización del art. $260 \mathrm{CP}$., sólo lo serán legítimamente cuando ejerzan funciones sometidas al control de la administración (ejemplo, control de legalidad, funcional o financiero) y que tengan la representación del Estado en el ejercicio de sus facultades. Desde esa perspectiva, los parlamentarios - sea Diputado o Senador -, al menos con relación a la potestad legislativa y política (no así a la administrativa), no reúnen todas las cualidades sobre las que se ha construido el concepto de "funcionario público" del art. $260 \mathrm{CP}$. La evolución del concepto en el último tiempo da cuenta, sin embargo, de una tendencia a la neutralidad y a la necesidad de cierta "generalización" por parte del legislador que podría atentar contra la conclusión de este análisis. Sin embargo, la mayor incompatibilidad de algunas de las funciones políticas y legislativas de los parlamentarios con los delitos funcionarios y, específicamente, con el delito de cohecho no está radicada en el concepto del art. $260 \mathrm{CP}$, sino que se va a expresar de manera mucho más clara con el concepto "cargo público" al que hace referencia específicamente el "injusto" del cohecho (art. 248 y ss. CP). Precisamente ahí, la naturaleza de las conductas de parlamentarios - en tanto, conductas en el ámbito de la ejecución de funciones no delegadas por la administración ni el Estado - va a encontrar su principal límite, como se demuestra en lo que sigue.

\subsection{Relación entre el concepto funcional de "empleado público" del art. $260 \mathrm{CP}$ y el concepto "cargo público" del delito de cohecho: (con)fusión material}

La relación del concepto de empleado público del art. 260 CP con los sujetos activos (o sujetos referidos en el objeto de la oferta/solicitud o aceptación/consentimiento) del delito de Cohecho del arts. 248, 248 bis y 250 es estrecha, pero no completamente coincidente. Precisamente dicho aspecto resulta ser relevante para este estudio, en tanto,

\footnotetext{
${ }^{90}$ ARANCIBIA, “Concepto de Empleado Público...”, cit. nota n79, p. 965.

${ }^{91}$ ARANCIBIA, “Concepto de Empleado Público...”, cit. nota n 79, p. 965.

${ }^{92}$ Historia de la Ley 19.645, Segundo Informe de Comisión de Constitución, Senado, sesión 26, Fecha 01 de septiembre, 1998. El abogado asesor del Ministerio Secretaría General de la Presidencia señor Rodrigo Medina defendió la tesis funcional, aunque con un contenido material claro. Aquello lo realizó en la discusión sobre la posible inclusión de gerente de empresas públicas al concepto del art. 260. Señaló que desde el punto de vista técnico, los tipos penales exigen requisitos y condiciones de actuación especiales que no se cumplen en todos los casos por los directores o gerentes de las empresas del Estado
} 
las exigencias del injusto del delito de cohecho son tan altas desde la perspectiva teleológica, sistemática y gramatical, que terminan incluso por limitar la conceptualización de "empleado público" del art. 260 CP. Mientras el concepto del art. 260 CP es compresivo de la amplia "primera línea de la administración del Estado y la gestión pública", abarcando a sujetos que realizan funciones públicas formal e informalmente (indistintamente como funcionarios y cargos públicos), lo claro es que los distintos tipos penales vinculados a dicho concepto pueden limitar o ampliar los alcances del mismo en la configuración de su propio injusto. Así, limitará el contenido del injusto específico de cada figura si exige concretamente sujetos con deberes especiales (o específicos) o los ampliará si permite la comprensión de sujetos que, sin mantener la relación material exigida por el art. $260 \mathrm{CP}$, se vinculan funcionalmente con el Estado. Un ejemplo de limitación por medio de la determinación de un ámbito concreto de destinatarios de la norma de conducta extrapenal (o deberes) lo representa, por ejemplo, el delito de violación de secretos del art. $246 \mathrm{CP}$ que sanciona sólo al empleado público que revelare los secretos de que tenga conocimiento por razón de su oficio. A la inversa, un ejemplo de extensión del concepto del art. 260, de manera funcional, lo representa la fijación del sujeto activo en el delito de malversación de caudales públicos del art. 233 y ss. CP (párrafo V.) que, para sus efectos, amplía el concepto de funcionario público por medio del art. $238 \mathrm{CP}$ a todo sujeto que, por cualquier concepto, administra fondos, rentas o efectos municipales o pertenecientes a un establecimiento público de instrucción o beneficencia. Otro ejemplo de esta ampliación funcional, más no formal, lo representaría la comprensión del certificador de programas de cumplimiento al que se refiere el art. 4 de la Ley $\mathrm{N}^{\circ} 20.393$.

Respecto del delito de cohecho (art. 248 y ss. CP), hay acuerdo en la doctrina en que si bien el empleado público se encuentra en el centro de la construcción de todos los tipos penales del párrafo IX del título $\mathrm{V}$ (cohecho), se debe además afectar deberes que no cualquier sujeto de los abarcados por el art. $260 \mathrm{CP}$ está llamado a cumplir. Aquello queda cristalizado típicamente en que, mientras el mencionado artículo $260 \mathrm{CP}$ se refiere a "empleados públicos" en general, comprendiendo a funcionarios públicos y cargos públicos, los artículos 248 y ss. CP. sólo hacen referencia a "cargos públicos": "recibir mayores derechos de los que le están señalados por razón de su cargo" (art. 248) o para ejecutar o haber ejecutado "un acto propio de su cargo" (248)/ para omitir (...) un acto debido propio de su cargo, o para ejecutar (...) un acto con infracción a los deberes de su cargo (art. 248 bis). El único delito, en su condición, que resulta ser excluido del "acto del cargo" es el de cohecho agravado del art. $249 \mathrm{CP}$, por tener como objeto los delitos de tortura y otros tratos crueles, inhumanos o degradantes, del párrafo IV del Título III del CP. Aun así, aquellos delitos se definen desde el abuso del cargo o función, lo que finalmente explica la innecesaria incorporación.

Cuando el legislador introduce el elemento "cargo público" en los delitos de cohecho, se refiere a "aquellos servidores del interés social o comunitario que pertenecen a la Administración del Estado", concepto asociado al bien jurídico protegido, cuestión ampliamente reconocida por la jurisprudencia penal. ${ }^{93}$ Con ello, en su momento, se habría hecho extensible un concepto funcional (relativo al interés social y comunitario) al estrictamente formal de la administración central del cargo público; con esta modificación - cristalizada en la ley $\mathrm{N}^{\circ} 13.211$ de 1958 - se abarcó también a

\footnotetext{
${ }^{93}$ Véase el concepto y la extensa jurisprudencia en ARANCIBIA, “Concepto de Empleado Público...", cit. nota ${ }^{\circ} 79$, p. 962 y ss.
} 
instituciones semifiscales o autónomas como las municipalidades o nombramientos que no recibía remuneración económica. ${ }^{94}$ En términos jurisprudenciales, acogiendo una perspectiva administrativa de la Ley $\mathrm{N}^{\circ} 18.834$ (Estatuto Administrativo) o la Ley $\mathrm{N}^{\circ} 18.883$, se ha entendido como todo cargo de planta (permanente) o contrata (temporal) en las instituciones de la administración del Estado que, a diferencia del concepto funcional de funcionario, requiere un acto formal de designación, remuneración en el presupuesto anual de la nación y normalmente sujeto a un régimen de calificación. ${ }^{95}$ El concepto "cargo público" para el derecho penal y específicamente para el delito de cohecho es, por cierto, distinto al concepto de "cargo" que ofrece el derecho público en general. La razón de la diferenciación dice relación con la distinta finalidad para la cuál ha sido diseñado cada concepto, aunque mantenga una vinculación funcional: las expectativas que se puede generar y garantizar al ciudadano en su relación con el Estado están organizadas en regulaciones extrapenales relativas a la administración de cada ámbito estatal y son dichos sistemas y orgánicas, diseñadas en base a deberes, las que son capaces de generar funcionalidad. Aquellas, sin embargo, exceden y son mucho más amplias que lo regulado por el estatuto administrativo. La limitación del concepto del art. 260 en relación con los arts. 248 y ss. CP, puede seleccionar algunos de dichos ámbitos y excluir a otros.

Como se señaló más arriba, el ámbito de protección del delito de cohecho es la capacidad de funcionamiento de la Administración del Estado, así como la confianza en dicho funcionamiento, entendidos, como decía Welzel, como la garantía del Estado al ciudadano de que, al interactuar con un servidor público, este no será "comprable" y, por lo mismo, no podrá falsificar la voluntad de los órganos del Estado. ${ }^{96}$ El injusto del cohecho activo y pasivo exige, por lo mismo, un sujeto al que se le ha delegado un poder por el Estado para gestionar sus funciones ejecutivas de acuerdo con los intereses generales, poder respecto del cual solicita/acepta desviar para obtener beneficios privados, defraudando el mandato legal o estatal. ${ }^{97}$ Se trata - siguiendo una idea expuesta por Kindhäuser - de sujetos titulares de deberes constitutivos de una garantía institucional de la gestión del interés social, en atención a su "especial" posición de deber en favor del Estado. ${ }^{98}$ De ahí que se debe aceptar que el concepto "cargo público" de los tipos de cohecho es uno acotado a sujetos específicos titulares de deberes emanados de un mandato legal/estatal que los ubica en una posición de deber en favor del Estado y que genera expectativas en los ciudadanos, y cuya desviación - objeto de negociación - es capaz de lesionar o poner en peligro el bien jurídico protegido.

A la interrogante sobre la compatibilidad entre la naturaleza del cargo, las funciones del parlamentario y el concepto del art. 260 en relación con los arts. 248 y ss., se debe contestar analizando los distintos tipos de deberes y obligaciones que recaen sobre él. Se debe aceptar, en efecto, que los parlamentarios deben regir su actuar según determinados deberes y mandatos en la ejecución de ciertas funciones e, incluso, que deben ceñirse a algunos deberes éticos o de probidad en su función política y legislativa (los deberes del art. $8^{\circ}$ inc. $1^{\circ}$ de la Carta Fundamental, artículos $5^{\circ}$ A y $5^{\circ}$ B de la Ley Orgánica sobre Congreso Nacional, artículo $8^{\circ}$ del Reglamento del Senado). Sin

\footnotetext{
${ }^{94}$ ARANCIBIA, “Concepto de Empleado Público...”, cit. nota n79, p. 963 y s.

${ }^{95}$ ARANCIBIA, “Concepto de Empleado Público...”, cit. nota nº79, p. 964.

96 WELZEL, "Studien ...", cit. nota n 9, p. 539

${ }^{97}$ NIETO GARCÍA, ALEJANDRO, Corrupción en la España democrática, Ariel, Barcelona, 1997, p. 7

${ }^{98}$ KINDHÄUSER, "Presupuestos...", cit. nota n50, pp. 6 y s.
} 
perjuicio de lo anterior, la vulneración de tales normas no coincide necesariamente con el tipo de infracción o tipo de acto del cargo al que se refiere el injusto del cohecho del art. 248 y ss. La actividad político-parlamentaria - y, en su principal manifestación, la función legislativa - resulta no ser coincidente con la lógica de las funciones delegadas a los funcionarios - titulares del cargo de ejecución pública - y que, por lo mismo, son funciones que pueden ser controlables en su bondad, eficacia, legalidad, profesionalismo/técnica y orientación por superiores administrativos.

La principal función de las dos ramas del Congreso, la Cámara de Diputados y el Senado es la legislativa, esto es, "la formación de las leyes en conformidad a esta Constitución" (art. 46 de la Constitución Política). Sin embargo, la misma Constitución ha asignado a ambas otras funciones adicionales, como la función representativa, presupuestaria (Art. 67), función de control o de fiscalización, jurisdiccional [art. 52 c) 2); 53 1)], incluso el ejercicio de funciones de organización y administrativas de los recursos puestos a disposición del ejercicio de su actividad parlamentaria. El cargo de parlamentario está vinculado entonces a una serie de funciones generales que, por mucho, exceden las meras decisiones de carácter político y legislativa/constituyente (art. 63 y ss.). Así, el art. 49 de la Constitución establece ciertas atribuciones y facultades exclusivas de la Cámara de Diputados en la actividad parlamentaria, relativa a la fiscalización política de los actos de gobierno, para lo cual dispone de una cierta cantidad de herramientas de carácter jurídico-político, tales como la facultad de adoptar acuerdos, de solicitar antecedentes de gobierno, citar a Ministros de Estado, crear comisiones investigadoras e, incluso, acusar constitucionalmente al Presidente de la República, Ministros de Estado, Magistrados de los Tribunales Superiores y del Contralor General de la República, por notable abandono de sus deberes, etc. Especialmente interesante son las funciones jurisdiccionales del Senado, tales como la de juzgar como jurado la culpabilidad en un proceso de acusación constitucional o la de conocer de las contiendas de competencia entre autoridades políticas o administrativas y los tribunales superiores de justicia (art. 53 1). En este contexto, el Congreso - e, incluso, sus Senadores y Diputados - debe asumir funciones administrativas internas relacionadas con la organización del Congreso, oficinas parlamentarias, asesorías, administración de presupuesto, etc. Dichas actividades, reguladas específicamente por la Ley N 18.918 de 1990, Orgánica del Congreso Nacional, reglamentos de la Cámara de Diputados y Senado y demás estatutos de carácter administrativo, se refieren a cuestiones organizativas internas que, aunque no forman parte de la Administración Central del Estado, constituyen funciones y potestades que emanan de un mandato legal o constitucional controlables.

De ahí que resulte especialmente importante distinguir las funciones, atribuciones y potestades desarrolladas por los parlamentarios y, a su vez, diferenciarlas según si aquellas son desarrolladas en torno a un mandato legal (administrativas) que exija el ejercicio de las mismas en torno a ciertos parámetros definidos por la Constitución, la ley o la autoridad o se trata de un mandato popular (político-legislativas) en cuyo caso no es posible su controlabilidad sustantiva.

El mandato popular de los parlamentarios en Chile referida a la función legislativa y política, según se desprenden de los arts. 5, 47 y 49 de la Constitución, es un mandato que proviene de la soberanía popular, que es general y representativa; esto es, si bien se trata de cargos elegidos directamente en circunscripciones limitadas territorialmente, hacen surgir mandatos nacionales que, a su vez, no vinculan al parlamentario a 
posteriores órdenes de los electores del territorio. El parlamentario, entonces, en su mandato popular expresa su voluntad autónoma, que es la voluntad soberana del pueblo. Por lo mismo, se sostiene que se trata de autoridades - en la función legislativa investidas de la voluntad soberana de quienes las eligen. Sus actuaciones en votaciones se rigen por su voluntad/conciencia y no resultan ser controlables por su mérito, oportunidad y conveniencia por otras instancias. Esta perspectiva, implica reconocer que los parlamentarios, así como no son representantes de intereses meramente territoriales o particulares de algún grupo específico, tampoco lo son de especiales intereses propios de la administración del Estado, actuando en absoluta libertad de conciencia esencialmente cuando se refiere a la actividad política y legislativa. La falta de cumplimiento a promesas de campaña - una especie de deslealtad a los discursos y propuestas desarrolladas por el político - no convierte al mandato parlamentario en revocable ni por parte de los partidos políticos ni por la ciudadanía. ${ }^{99}$ De ahí que las decisiones que constituyen manifestación del mandato popular - en el ámbito político y legislativo - reúnan una naturaleza especial, distinta al mandato meramente estatal, ejecutado por un funcionario o empleado público. Esto es, no son decisiones que sustancialmente - en su contenido - puedan calificarse como "infracciones a deberes", de los que se haga depender la funcionalidad de la administración o que impliquen desviación del mandato estatal, ni pueden regirse materialmente por políticas de gestión pública dictadas por otras autoridades superiores.

Resulta de especial apoyo el análisis que, para estos mismos efectos, se ha desarrollado por la literatura alemana. Esta destaca una diferencia sustancial entre el mandato del funcionario público y el del parlamentario en sus funciones "legislativas", que impediría analogarlos para efectos del injusto del cohecho. La naturaleza del vínculo del empleado público con la administración del Estado lo somete a una relación de subordinación frente a las instrucciones y decisiones de superiores jerárquicos, y, de ahí, a un mandato de representación limitado a ciertos deberes legales o funcionales de la administración pública; aun así, es sustituible y sus funciones pueden ser controladas, delegadas a otra persona o revocadas por un superior. En cambio, "los titulares de un mandato popular, para efecto de sus decisiones, no son representables ni sustituibles y están sujetos sólo a su consciencia"; se trata de un mandato personal de representación popular y no del Estado o su administración. Aquella "irremplazabilidad" del parlamentario es esencial, en tanto los intereses particulares que permitieron elegir al diputado como un representante del pueblo, juegan un rol relevante." ${ }^{100}$ Así lo han aceptado emprendiendo una solución a un problema similar al chileno - autores alemanes como Samson y Rudolphi. ${ }^{101}$

Debido a lo anterior es que, a diferencia de España ${ }^{102}$ o Italia, ${ }^{103}$ en Inglaterra, Austria ${ }^{104}$ o Alemania la labor legislativa como una función pública no es abarcada por el delito de

\footnotetext{
${ }^{99}$ Véase sobre modelos comparados en: VAN DER HULST, Marc, El mandato parlamentario, un estudio comparado, Unión Interparlamentaria, Ginebra, 2000, Suiza, pp. 10 y ss.

100 FRANCUSKI, Ramona, "Die Neuregelung der Abgeordnetenbestechung (§ 108e StGB)", en: Onlinezeitschrift für Höchstrichterliche Rechtsprechung zum Strafrecht (HRRS), Julio, 2014.

101 SAMSON, Erich/ RUDOLPHI, Hans-Joachin. , § 11, en: Rudolphi/Stein (Coord.), Systematischer Kommentar zum Strafgesetzbuch, 7. Ed., Februar 2005, § 11, nm. 20 (en la primera edición de 1975, § 11, nm. 13)

102 Art. 24.1 CP: “(...) En todo caso, tendrán la consideración de autoridad los miembros del Congreso de los Diputados, del Senado, de las Asambleas Legislativas de las Comunidades Autónomas y del Parlamento Europeo (...)".
} 
cohecho de funcionarios públicos destinado a proteger a la administración del Estado. Ella es reorientada, por medio de nuevos tipos penales, a lo que realmente interesa a esta constelación de casos: la protección del correcto "desarrollo de la democracia y el mandato popular".

En el caso de Alemania la conducta del parlamentario no se entendía comprendida en el delito de cohecho de los parágrafos 331 StGB y ss., precisamente por su incompatibilidad con el ámbito de protección y su configuración de injusto. Por lo anterior, el legislador debió incorporar en 1994 un nuevo delito específico en el parágrafo 108e del StGB (CP alemán). En dicho tipo penal, como ya se adelantó, se establecieron hipótesis de cohecho activo y pasivo a quien trate de comprar o vender un voto para una elección o votación al Parlamento Europeo, a una cámara de representantes federal o de Estados federados de Alemania, a un ayuntamiento o a una asociación de municipios. Aquella decisión tuvo su fuente primaria en una decisión del Bundesgerichtshof (BGH) de 1953 que señaló que si bien los parlamentarios ejercen "potestades de derecho público" ("öffentlichrechtliche Befugnisse") no serían verdaderos empleados públicos en el sentido penal ${ }^{105}$ (opinión desarrollada especialmente por el BGH alemán con fecha 6 de mayo de 2006) ${ }^{106}$. Así, entonces, a través de este nuevo tipo penal que tiene como sujeto activo al parlamentario y que sanciona la venta del voto, ya no se protege "el correcto funcionamiento de la Administración Pública", contra conductas desleales de quienes han recibido por delegación la ejecución de esas funciones [ya que derechamente no se lesiona ni pone en peligro], sino concretamente "el proceso de conformación de las decisiones parlamentarias y el correcto funcionamiento del sistema representativo, la independencia y libertad del ejercicio del mandato político y la confianza de la sociedad en este.". ${ }^{107}$ En su configuración actual, precisamente para no limitar o impedir la libertad de la labor parlamentaria [aspecto de especial cuidado para el legislador alemán], el nuevo tipo penal - que vino a solucionar esta laguna - ha sido especialmente limitado por el mismo BGH a concretos acuerdos ilícitos, excluyendo expresamente las hipótesis de "Anfüttern" (pagos genéricos). En conclusión, el injusto del delito de cohecho de empleados públicos (en tanto acuerdo ilícito que requiere una deslealtad a la representación del Estado), para el caso de los parlamentarios, consiste en la "comercialización del mandato popular" que, en el caso del parágrafo 108e StGB, estaría relacionado con una vulneración al Art. 38 Abs. 1 de la Constitución (GG).

Especialmente interesante de esta tendencia comparada a criminalizar directamente la conducta de parlamentarios es, entonces, la restricción de la punibilidad sólo a hipótesis de compra de un votación específico, ya que la mayoría de los actos políticos entre los

\footnotetext{
${ }^{103}$ El Art. 357 inc. 1, del Código Penal italiano amplía la punibilidad a los parlamentarios, definiendo expresamente como Funcionario Público a todos quienes ejerzan funciones en el poder legislativo, judicial o la administración; de ahí que el Cohecho de los Art. 318 y ss. C.P. serían directamente aplicables.

${ }^{104} \S 304 \mathrm{a}$ del Código Penal austríaco o des österreichischen Strafgesetzbuchs (öStGB) sanciona la compra o la venta de un voto en el parlamento.

${ }^{105}$ NIEHAUS, Holger, "Zur Korruptionsstrafbarkeit kommunaler Mandatsträger Zugleich Anmerkung zur Entscheidung des BGH vom 9.5.2006 - 5 StR 453/05", en: Zeitschrift für Internationale Strafrechtsdogmatik -, pp. 49-56, p. 51 y ss. (http://www.zis-online.com/dat/artikel/2008 1_204.pdf ) [Visitado el 02.02.2018].

${ }^{106}$ En español, véase NIETO, "El concepto...", cit. nota n¹1, p. 92.

107 MÖHRENSCHALAGER, M., "8. Kapitel. Der strafrechtliche Schutz gegen Korruptionen", en: DÖLLING, Dieter, Handbuch der Korruptionsprävention für Wirtschaftsunternehmen und öffentliche Verwaltung, Beck Verlag, p. 424.
} 
que se encuentran las opiniones políticas, la presentación de proyectos de Ley, los discursos a favor de una determinada opción o las actuaciones del parlamentario dentro de su propio grupo parlamentarios, no son necesariamente actos arbitrarios o capaces de ser desviados. ${ }^{108}$ Nieto, al respecto acentúa, que los actos políticos no son mejores o peores - cuestión que es esencial en la falsedad de la voluntad del Estado o en la desviación de funciones [nuestro] - porque provengan de un acto ilícito de Lobby. ${ }^{109}$ Destaca, haciendo referencia a las criminalizaciones especiales a nivel europeo - que el cohecho de parlamentarios, a diferencia del de funcionarios - se parece más al financiamiento irregular de la política. Esto, porque lo protegido ya no es tanto la corrección de las decisiones o su imparcialidad, sino más bien la democracia y la formación de la voluntad general (incorruptibilidad de parlamentarios) ${ }^{110}$.

En los modelos - como el español o el italiano - en que los legisladores y demás autoridades elegidas popularmente podrían potencialmente ser abarcados por el injusto del cohecho, aquello sería posible por dos razones: i) porque una parte de la dogmática ha entendido como correcto un modelo infraccional del injusto no basado en la deslealtad", esto es, acepta proteger un bien jurídico más amplio (confianza en la institución como reputación moral) y, por lo mismo, el desvalor de la conducta, a diferencia de los tipos penales nacionales, se concreta en la mera "vulneración a normas de probidad"; 2) porque adopta una configuración típica más amplia que permite la introducción como ilícita de conductas desleales en el ámbito de estatal general. En efecto, en el caso español (art. 419 y ss. en relación al art. 24 Código Penal) la posibilidades de abarcar los actos parlamentarios generales está radicado en la definición legal del concepto "autoridad" del art. $24 \mathrm{CP}$ español que es lo suficientemente amplia como para comprender a miembros del Congreso de los Diputados, del Senado, de Asambleas legislativas de Comunidades autónomas o del Parlamento Europeo; mientras que el art. $419 \mathrm{CP}$, como tipo de cohecho, ha eliminado de su configuración el elemento "desviación del cargo", radicando su ilícito en la mera infracción de "reglas de probidad". ${ }^{111}$ Precisamente este ha sido el modelo seguido por nuestro Ministerio Público, sin consideración a las diferencias valorativas, sistemáticas y estructurales de nuestras figuras penales. Ya se ha demostrado, más arriba, que aquella lectura del delito de cohecho "en razón del cargo" es interpretada también por otra parte de la literatura desde la perspetiva del acuerdo ilícito, lo que impede la interpretación meramente moral.

\subsection{Excurso}

Lo anteriormente señalado está referido exclusivamente a la incompatibilidad entre la naturaleza del mandato al cual pertenece la función legislativa (mandato popular) - que se concreta en una decisión política -, con el bien jurídico protegido (administración pública) y el tipo de injusto de los delitos de Cohecho del art. 248 y ss. del CP y que se concreta en la gestión administrativa (mandato estatal). Sin perjuicio de lo anterior, el interés público por no restringir y controlar ciertos aspectos limitados sólo a la actividad legislativa, fundado en la misma idea anterior, encuentra también expresión en otros institutos propios del derecho público que forman un modelo específico de control.

\footnotetext{
${ }^{108}$ NIETO, "El concepto...", cit. nota n¹1, p. 92 u s.

${ }^{109}$ NIETO, "El concepto...", cit. nota ${ }^{\circ} 11$, p. 93.

${ }^{110}$ NIETO, "El concepto...", cit. nota n`11, p. 93.

${ }^{111}$ Véase explicación en HERNANDEZ, "La inconveniente...", cit. nota $n^{\circ} 51$, p. 18.
} 
Estos institutos no apoyan una idea de impunidad ni cristalizan un ámbito al margen del derecho $^{112}$, sino dan cuenta de un modelo de controlabilidad y responsabilidad política determinado - en el que se incorpora también el derecho penal - que da cuenta de la relevancia institucional y jurídica de la actividad política y función legislativa, al punto de no poder ser tratada con "indiferencia dogmática".

En primer lugar, ya es reconocido por la cultura jurídica nacional que los actos políticos - actos legislativos, escrutinios políticos y, por cierto, los actos de gobierno -, a diferencia de los actos de gestión pública (subordinados a decisiones superiores de la administración) no deben ser controlados, por ejemplo, por la Contraloría General de la República. ${ }^{113}$ En segundo lugar, nuestro ordenamiento jurídico ha optado en este sentido - existiendo modelos alternativos de control judicial a la actividad política en algunos pocos países - por garantizar niveles importantes de independencia de los parlamentarios y la absoluta libertad de acción de sus miembros respecto de sus votaciones, como la inviolabilidad parlamentaria establecida históricamente (art. 42 de la Constitución de 1828; art. 14 de la Constitución de 1833; art. 32 de la Constitución de 1925 y actualmente en el art. 61 de la Constitución Política, art. 58 original): "Los diputados y senadores sólo son inviolables por las opiniones que manifiesten y los votos que emitan en el desempeño de sus cargos, en sesiones de sala o de comisión. (...)”. Aquella norma constitucional se basa en la idea de garantizar la libertad para expresar la opinión y votar en el parlamento, lo que se limita a materias que "deben ser las propias del ejercicio del cargo, las que conlleven la facultad de fiscalizar o de legislar o de opinar, según los casos". ${ }^{114}$ El fundamento de tal disposición no era, precisamente, citando a Silva Bascuñán, colocar a diputados y senadores al margen del ordenamiento jurídico "sino tan sólo de asegurar la independencia de estos cargos, la libertad de las determinaciones y actuaciones de quienes, temporalmente, los sirven, y de proveer los medios adecuados a esos objetivos". ${ }^{115}$ Con este argumento no se quiere sostener que el constituyente haya establecido una especie de "derecho" para emprender conductas ilícitas en el desarrollo de la actividad parlamentaria, sino sólo que ha reconocido por medio de esta institución, un especial interés por garantizar niveles de libertad de la opinión política y no intromisión de controles externos exclusivamente a la labor legislativa. ${ }^{116}$ Así las cosas, se debe considerar seriamente - como lo denuncia Vázquez-Portomeñe - que al ser abarcado el parlamentario por el delito común de cohecho en su función política y legislativa se corre el riesgo de proponer un "examen penal" de desviación constitucional en un ámbito en que rige el principio de irresponsabilidad por los votos y opiniones. ${ }^{117}$ Una deseable modificación al modelo de controlabilidad de no sujeción de los parlamentarios al principio de imparcialidad y objetividad, ${ }^{118}$ es una decisión institucional que, si bien es posible cristalizarla de

\footnotetext{
${ }^{112}$ Una crítica a esta posición véase en GUZMÁN DALBORA, “Cohecho político...”, cit. nota n¹1, p. 245 y s.

${ }^{113}$ Véase MORALES, Baltazar, "El mérito, oportunidad y conveniencia en la Contraloría General de la República”, en: Contraloría General de la República 85 años de vida institucional (1927-2012), pp. 207220 p. 213.

${ }^{114}$ Véase en Actas Oficiales de la Comisión Ortuzar, Sesión Nº 346 del 05 de abril de 1978.

115 SILVA BASCUÑ́́N, Alejandro, Tratado de Derecho Constitucional, T. II, Edit. Jurídica, Santiago., p. 60

${ }_{116}^{\text {p. }}$ En este mismo sentido en español, véase NIETO, "El concepto...”, cit. nota n¹1, p. 93.

${ }^{117}$ VASQUEZ-PORTOMEÑE, Fernando, Los Delitos contra la Administración Pública, Ed. Universidad Santiago de Compostela, p. 53.

${ }^{118}$ VAZQUEZ-PORTOMEÑE, Los Delitos, cit. nota n ${ }^{\circ} 117$, p. 55.
} 
manera especializada, limitada y concreta, no ha sido concretada absolutamente en nuestro país.

Dos aclaraciones, sin embargo, deben ser formuladas. La primera, dice relación con que cuando hacemos referencia a los modelos de controlabilidad, no estamos ubicando las conductas de los parlamentarios en una esfera exenta del derecho, al punto que un acto no objetivo o parcial no pueda llegar a ser antijurídico. Sólo hacemos referencia a modelos de regulación del control positivados en nuestro ordenamiento ( se entrega excepcionalmente a otra institución política o a los tribunales el control jurídico-político de sus decisiones?). La segunda aclaración, se refiere a que incluso si se concediera a Nieto Martín y a Guzmán Dalbora, que la argumentación anterior sólo se refiere al acto político de la votación o de la emisión de una opinión política y no a actos anteriores a él posibles de ser separados de la deliberación - como cuando obstaculiza el proceso legislativo -, ${ }^{119}$ aquello no tendría efectos en el tipo penal de cohecho de los art. 248 y ss. Aquello, no sólo es consecuencia del tipo de exigencia del tipo penal, sino esencialmente porque no es posible conceder que desde la perspectiva penal el ámbito de protección coincida con la función parlamentaria.

\section{Acto del empleado público como contrapartida pasiva del cohecho activo del particular: ¿comprensión de actos del cargo neutros?}

La punibilidad de la compra del voto o de la actitud favorable del parlamentario a una causa, depende de varias variables. Dos de esas variables deben ser problematizadas aquí, en tanto ya se ha concluido que, respecto del parlamentario en su función legislativa, no es posible aceptar la calificación de "desviación de funciones" o infracción de deberes que constituyan deslealtades a la voluntad del Estado. Una problematización dice relación con la posibilidad de que los delitos de cohecho abarquen hipótesis neutras (entre ellas, las que no impliquen idoneidad lesiva) y, la otra, con la posible existencia de hipótesis delictivas que abarquen promesas futuras difusas, no concretas. Ambas variables en sí mismas no resuelven el problema de manera absoluta, sino sólo parcialmente. Una interesante y fundada opinión- aunque genérica y no referida específicamente a la regulación nacional - que justifica esta discusión, es la de Guzmán Dalbora que sostiene que las conductas torcidas de los parlamentarios son antijurídicas y pueden constituir el delito de cohecho. Las posibilidades de la punibilidad de estas constelaciones, señala, podrían reunir las características de cohecho impropio, y de cohecho subsiguiente o la corrupción del que acepta dádivas que le son ofrecidas en consideración a su función y no necesariamente para que realice u omita un acto preciso. ${ }^{120}$ Aquella opinión de lege ferenda, sin embargo, no puede ser aceptada en un análisis de lege lata, como se demostrará. También justifica este análisis, como ya se ha señalado más arriba, que en la actualidad se discute en el Congreso Nacional un proyecto de Ley que establece en el art. $248 \mathrm{CP}$ el llamado cohecho "en razón del cargo", en los mismos términos propuestos por Gunzmán Dalbora.

\subsection{Análisis de lege lata}

\footnotetext{
119 NIETO, “El concepto...”, cit. nota n¹1, p. 94; GUZMÁN DALBORA, “Cohecho político...”, cit. nota $\mathrm{n}^{\circ} 11$, p. 243 y s.

${ }^{120}$ GUZMÁN DALBORA, “Cohecho político...", cit. nota n¹1, pp. 240 y ss.
} 
El cohecho se encuentra regulado en los arts. 248 y ss., estableciendo distintas hipótesis que son consecuencia de la combinación entre variados elementos ubicados en los arts. 248, 248 bis, 249 y 250: 1) conducta activa (ofrecer) y pasiva (consentir); 2) Prestación: una ventaja (beneficio económico) en provecho de éste (sobornante) o de un tercero; 3 ) contraprestación antecedente: para realizar acciones u omisiones señaladas en el art. 248, 248 bis o 249 o 4) contraprestación subsiguiente: por haberla realizado o haber incurrido en ellas. Parte central de estas vinculaciones - de las que depende el desvalor de las conductas -, radica en la vinculación entre el ofrecimiento (oferta) y su contraprestación, que tiene como objeto cualquiera de las acciones u omisiones del art. 248,248 bis y 249). Aquellas combinaciones deberían expresar, ofertas o incentivos a producir acuerdos de dar algo de valor a cambio de influir en la toma de decisiones o acciones. El problema surge en algunas combinaciones excepcionales que no son capaces de cristalizar el injusto del cohecho como "acuerdo ilícito" y que cubren hipótesis neutras desde el punto de vista de la función pública: el ofrecimiento del particular al funcionario público (o la solicitud inversa) de una ventaja a cambio de un acto del cargo que no representa una desviación de funciones o una deslealtad a la voluntad al Estado, también se encuentra cubierta - al menos gramaticalmente - por la combinación entre el art. 250 y el art. 248 [véase cuadro anexo infra].

Esa perspectiva gramatical, apoyada por las tesis de lesividad acumulativa, posibilita lecturas que entienden el injusto del delito de cohecho como una mera lesión al Ethos de la probidad; y más específicamente, como una mera vulneración al art. $64 \mathrm{n}^{\circ} 5$ de la Ley $\mathrm{N}^{\circ} 18.575$ de 2000, que señala que contraviene el principio de la probidad administrativa, el que solicita, se hace prometer o aceptar - en razón del cargo o función - donativos, ventajas o privilegios de cualquier naturaleza. Aquella norma, por cierto no se aplica a la función parlamentaria que, a su vez, tiene sus propias normas éticojurídicas, como los deberes del art. $8^{\circ}$ inc. $1^{\circ}$ de la Carta Fundamental, artículos $5^{\circ}$ A y $5^{\circ} \mathrm{B}$ de la Ley Orgánica sobre Congreso Nacional y que son limitadas a la naturaleza de la función.

El análisis desarrollado aquí sobre injusto del cohecho - desde una perspectiva moral, ${ }^{121}$ conceptual (supra) o teleológica (supra) - ha arrojado como conclusión que el objeto del cohecho activo del particular (ofrecer) tendrá siempre como contrapartida (prestación/contraprestación) una conducta del funcionario público que manifieste absolutamente la contracara "injusta" del acuerdo ilícito; esto es, una conducta de deslealtad del empleado público en relación con su deber para con el Estado tanto en la representación del interés estatal en la gestión como en su facultad de representación del Estado frente a terceros. ${ }^{122}$ Sin perjuicio de lo anterior, no todas las combinaciones que pudieran resultar de la vinculación de elementos entre el art. $250 \mathrm{CP}$ y los tipos penales de referencia (arts. 248, 248 bis y 249) tienen ese mismo sentido valorativo, al punto de poder diluirse en algunas de ellas.

El que del examen de las combinaciones entre los arts. 248 y 250 se demuestre que en dos de las hipótesis no siempre se expresa el contenido de la "orientación" al acuerdo injusto en un contexto de corrupción, obliga a asumir una posición (con acentuación a una interpretación gramatical o teleológica, considerando sus efectos sistemáticos). Se opta por interpretar la sistemática normativa desde una perspectiva literalista que acepte

\footnotetext{
${ }^{121}$ GREEN, Mentir, cit. nota ${ }^{\circ} 42$, pp. 257 y ss.

${ }^{122}$ Véase KINDHÄUSER, "Presupuestos...", cit. nota n50, p. 7.
} 
hipótesis de cohecho por mera liberalidad (con ello, aceptando adoptar una lógica moralista o, a lo menos, formalista) o se busca un sentido lógico a las hipótesis aparentemente neutras que mantengan la lógica del "acuerdo ilícito". Una tercera alternativa para el rechazo del cambio de modelo es entender que el resultado de estas dos hipótesis conflictivas es sólo el efecto de la técnica legislativa utilizada (división de la conducta activa y pasiva), que debe ser corregida ya sea eliminando la hipótesis neutras o exigiendo una cualificación adicional que exprese el objeto injusto de la solicitud/aceptación/ofrecimiento/consentimiento. En realidad, como se demostrará, no es necesario inclinarse por los extremos.

Si se analizan las distintas combinaciones, se puede observar que la idoneidad lesiva no se expresa en todas hipótesis de manera similar, en particular en las activas del particular:

\begin{tabular}{|c|c|c|c|c|c|c|c|}
\hline \multicolumn{4}{|c|}{ Cohecho Antecedente } & \multicolumn{4}{|c|}{ Cohecho Antecedente } \\
\hline \multirow[t]{2}{*}{$\begin{array}{l}\text { Delito } \\
\text { Cohecho } \\
\text { activo } \\
\text { funciona } \\
\text { rio } \\
\text { Público } \\
\text { Art }\end{array}$} & \multicolumn{2}{|l|}{ Objeto ilícito } & $\begin{array}{l}\text { Relación de } \\
\text { lesividad } \\
\text { con el bien } \\
\text { jurídico }\end{array}$ & $\begin{array}{l}\text { Delito } \\
\text { Cohecho } \\
\text { pasivo } \\
\text { del } \\
\text { particula } \\
\text { r }\end{array}$ & \multicolumn{2}{|l|}{ Objeto ilícito } & $\begin{array}{lr}\text { Relación } & \text { de } \\
\text { lesividad con } & \text { el bien } \\
\text { el } & \text { jurídico }\end{array}$ \\
\hline & \multicolumn{2}{|c|}{ Solicitud condicional de } & \multirow[b]{2}{*}{$\begin{array}{l}\text { Idoneidad - } \\
\text { distorsiona } \\
\text { dora, en } \\
\text { tanto } \\
\text { condiciona } \\
\text { y entorpece } \\
\text { el ejercicio } \\
\text { de la } \\
\text { función } \\
\text { pública a la } \\
\text { recepción } \\
\text { de mayores } \\
\text { derechos }\end{array}$} & \multirow{3}{*}{\multicolumn{2}{|c|}{ 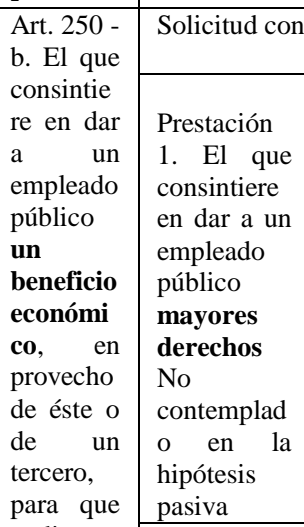 }} & \multirow[b]{2}{*}{$\begin{array}{l}\text { Contrapre } \\
\text { stación } \\
\ldots \text { para } \\
\text { ejecutar } \\
\text { un acto de } \\
\text { su cargo } \\
\text { No } \\
\text { contempla } \\
\text { do en la } \\
\text { hipótesis } \\
\text { pasiva }\end{array}$} & \\
\hline $\begin{array}{l}\text { Art. } 248 \\
\text { a. El } \quad \text { empleado } \\
\text { público } \\
\text { que } \\
\text { solicitare } \\
\text { recibir } \\
\text { mayores } \\
\text { derechos } \\
\text { de los } \\
\text { que le } \\
\text { están } \\
\text { señalado } \\
\text { s por } \\
\text { razón de } \\
\text { sucaroo }\end{array}$ & $\begin{array}{l}\text { Solicitud } \\
\text { 1. solicite recibir } \\
\text { mayores } \\
\text { derechos de los } \\
\text { que le están } \\
\text { señalados por } \\
\text { razón de su cargo, }\end{array}$ & $\begin{array}{l}\text { Prestación } \\
\ldots \quad \text { para } \\
\text { ejecutar un } \\
\text { acto de su } \\
\text { cargo }\end{array}$ & & & & & \\
\hline su cargo, & \multirow{2}{*}{$\begin{array}{l}2 . \quad \text { solicite un } \\
\text { beneficio } \\
\text { económico ... }\end{array}$} & \multirow[b]{2}{*}{$\begin{array}{l}\ldots \text { para } \\
\text { ejecutar un } \\
\text { acto de su } \\
\text { cargo }\end{array}$} & \multirow[b]{2}{*}{$\begin{array}{l}\text { Alto grado } \\
\text { de } \\
\text { neutralidad } \\
\text { Propuesta: } \\
\text { Idoneidad } \\
\text { distorsiona } \\
\text { dora, se } \\
\text { produce } \\
\text { sólo en la } \\
\text { medida que } \\
\text { la solicitud } \\
\text { proveniente } \\
\text { del } \\
\text { funcionario } \\
\text { que } \\
\text { ilicitamente } \\
\text { condiciona } \\
\text { el ejercicio } \\
\text { de la } \\
\text { función } \\
\text { pública si y } \\
\text { sólo si se } \\
\text { da } \\
\text { cumplimien } \\
\text { to de la } \\
\text { contraprest } \\
\text { ación }\end{array}$} & & & & \\
\hline $\begin{array}{l}\text { o un } \\
\text { beneficio } \\
\text { económic } \\
\text { o para sí } \\
\text { o un } \\
\text { tercero } \\
\text { para } \\
\text { ejecutar } \\
\text { o por } \\
\text { haber } \\
\text { ejecutado } \\
\text { un acto } \\
\text { propio } \\
\text { de su } \\
\text { cargo en } \\
\text { razón del } \\
\text { cual no le } \\
\text { están } \\
\text { señalados } \\
\text { derechos, } \\
\text { será } \\
\text { sanciona } \\
\text { do con } \\
\text { … }\end{array}$ & & & & $\begin{array}{l}\text { realice } \\
\text { las } \\
\text { acciones } \\
\text { o incurra } \\
\text { en las } \\
\text { omisione } \\
\text { s señaladas } \\
\text { en los } \\
\text { artículos } \\
248, \\
\text { Tratándo } \\
\text { se del } \\
\text { beneficio } \\
\text { ofrecido } \\
\text { en relación } \\
\text { con las } \\
\text { acciones } \\
\text { u } \\
\frac{\text { omisione }}{\text { s del }} \\
\frac{\text { artículo }}{\mathbf{2 4 8} \text { el }} \\
\text { sobornan } \\
\text { te será }\end{array}$ & $\begin{array}{l}\text { 2. El que } \\
\text { consintiere } \\
\text { en dar a un } \\
\text { empleado } \\
\text { público un } \\
\text { beneficio } \\
\text { económico } \\
\ldots\end{array}$ & $\begin{array}{l}\ldots \quad \text { para } \\
\text { ejecutar } \\
\text { un acto de } \\
\text { su cargo }\end{array}$ & $\begin{array}{l}\text { Esta hipótesis } \\
\text { es en } \\
\text { principio } \\
\text { neutra Una } \\
\text { solución sería } \\
\text { comprender } \\
\text { que solo tiene } \\
\text { sentido } \\
\text { distorsionador } \\
\text { si se trata } \\
\text { del abuso de } \\
\text { los } \\
\text { procedimient } \\
\text { os legales } \\
\text { utilizados en } \\
\text { favor de un } \\
\text { interés } \\
\text { particular o } \\
\text { porque su } \\
\text { realización no } \\
\text { se justificada } \\
\text { por sí mismo } \\
\text { (sino, sólo } \\
\text { por la } \\
\text { intervención } \\
\text { del }\end{array}$ \\
\hline $\begin{array}{ll}\text { do } & \text { con } \\
\ldots . & \end{array}$ & & & & $\begin{array}{l}\text { sanciona } \\
\text { do, } \\
\text { además, } \\
\text { con la } \\
\text { pena de }\end{array}$ & & $\begin{array}{lr}\ldots & \text { para } \\
\text { omitir } & \text { un } \\
\text { acto del }\end{array}$ & $\begin{array}{l}\text { sobornador), } \\
\text { Idoneidad } \\
\text { distorsionador } \\
\text { a, en la } \\
\text { medida que }\end{array}$ \\
\hline
\end{tabular}



actividad parlamentaria con el delito de cohecho (art. 248 y ss. CP).

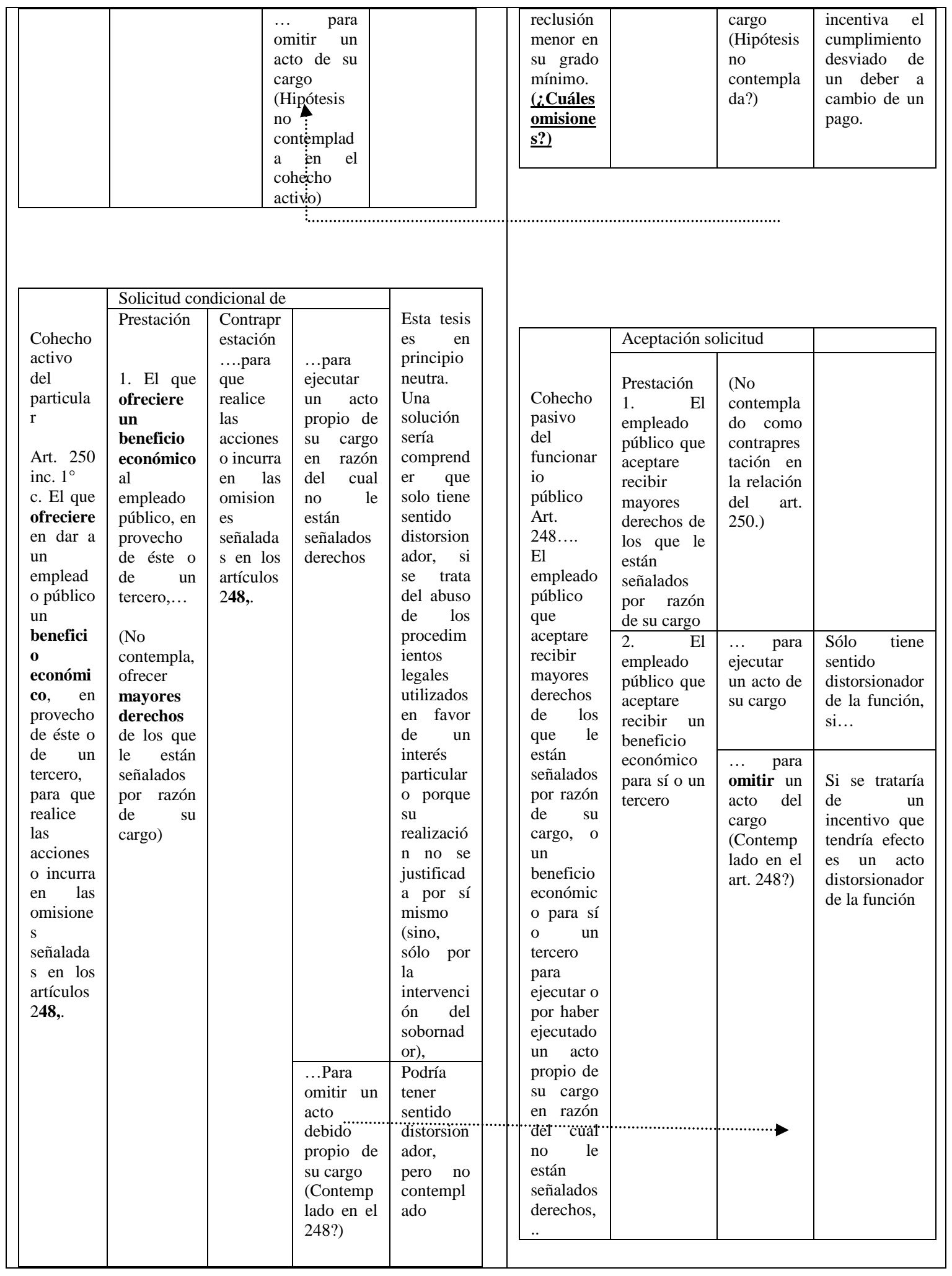

En la hipótesis activa del funcionario público (art. 248), por cierto, no genera problemas el hecho de ser neutro el contenido del "acto propio del cargo" (realizar legalmente la conducta), en tanto el desvalor de la conducta puede estar radicado en que éste sujeto especial solicita más derechos de los que están exigidos para aquel acto o solicita un beneficio económico condicional a la realización del acto del cargo; la distorsión de funciones no está referida concretamente al contenido del acto (como desviado), sino a 
la formulación de una "condicionante" para cumplir con el deber. Un contenido distorsionador se podría presentar también cuando se vincula la realización de un acto del cargo neutro (art. 248) con la conducta omisiva en la hipótesis del cohecho activo del particular (ofrecer) o pasivo (consentir en dar) del particular (art. 250). Esto, porque la omisión del deber es suficiente para tener por desviada la función, sin necesidad de atender a una desviación adicional. Sin perjuicio de lo anterior, esta hipótesis no se encuentra abarcada en esta combinación [véase anexo], sino sólo aceptada como posible por la regla que fija la pena de la combinación del cohecho activo del particular (art. 250 en relación con el art. 248) y que se encuentra ubicada en el inc. $2^{\circ}$ del art. 250.

Genera problemas, sin embargo, la hipótesis de cohecho del particular (art. $250 \mathrm{CP}$ ) que ofrece un beneficio económico [no incluida la hipótesis de más derechos] al funcionario público a cambio de la ejecución de un acto neutro propio del cargo. Esto porque dicha hipótesis, como ya se ha señalado, literalmente no manifiesta el desvalor del "acuerdo injusto", en tanto no es el mero ofrecimiento de un beneficio lo que se encuentra desvalorado como injusto penal, sino la disposición desleal (o de la voluntad estatal) sobre la función pública delegada. ${ }^{123}$ Interesante, por ir en esta dirección, resulta el voto disidente de los Ministros de la Corte Suprema señores Juica y Dahm, en el caso FIPES/Walker (Rol N ${ }^{\circ}$ 2996-17) que parece exigir, en el considerando $7^{\circ}$, la necesidad previa de indagar si ha sido el parlamentario imputado quien hizo la solicitud o no, ya que de aquello depende la imputación y su desvalor.

Más complejo que lo anterior, resulta ser el cohecho del particular (art. 250) que es consecuencia de un ofrecimiento del funcionario público (art. 248), en tanto la conducta - el consentir dar a un empleado público un beneficio económico - no tiene directamente sentido ni idoneidad distorsionadora de la función (sólo incumplimiento de deberes de probidad por parte del funcionario y una liberalidad sin objeto ilícito por el particular). En realidad, el privado es más bien víctima de un condicionamiento ilícito más o menos intenso que le impide gratuitamente acceder a la función pública. ${ }^{124} \mathrm{La}$ aceptación de estas hipótesis neutras como delictivas, modificarían asistemáticamente el modelo de regulación, además de abarcar conductas meramente infraccionales como delictivas. Una interpretación como esa, implicaría disminuir la funcionalidad de la técnica legislativa del art. 250 en relación al art. 248 sólo a ser un limitador de las hipótesis "Klimapflege" (ofertas generalizantes), pero en lo demás incluso más amplia que al modelo español del art. 422 ("La autoridad o funcionario público que en provecho propio o de un tercero, admitiera (...) dádiva o regalo que le fueren ofrecidos en consideración a su cargo o función") que, como ya se ha señalado, es diferente al adoptado por el legislador nacional. Se trataría, como se verá más adelante, de una criminalización de conductas en que no sólo se eliminaría el acuerdo ilícito (se suprime como momento de consumación), sino que además la exigencia de determinar el objeto ilícito de la contraprestación en el acuerdo, que debe ser tomada como referencia de los actos del cargo. ¿Existirá alguna explicación que no implique tener que modificar el sentido injusto de la conducta y su sistemática y aceptar esta tesis que le exige al particular soportar un acto injusto reforzado con una amenaza penal?

\footnotetext{
${ }^{123}$ NIETO MARTÍN, "La corrupción”, cit. nota n97, p. 68, defiende la impunidad de la hipótesis neutra; en ese mismo sentido DE LA MATA BARRANCO, Norberto, ¿Qué interés lesionan las conductas de corrupción?, en: EGUZKILORE, Número 23. San Sebastián, diciembre 2009, p. 258.

${ }^{124}$ Entre la hipótesis de cohecho activo del privado (art. 250) en relación al art. 248 - esto es, el llamado cohecho impropio - se produce superposición con la hipótesis del art. 241 CP (exacción ilegal). Un interesante análisis sobre el punto, véase en ARTAZA, "La utilidad del concepto...”, cit. nota n5, p. 334 y s.
} 
Las hipótesis del cohecho del particular son generalmente explicadas por su idoneidad para incentivar la conducta ilícita, desviada o desleal del funcionario público. Su desvaloración radica precisamente en su capacidad - por medio de su oferta económica - para inducir al funcionario público a realizar un acto desleal o de desviación del acto del cargo (desleal a la voluntad estatal). En la hipótesis de cohecho del privado, en la combinación entre el art. 250/248, podría comprender sólo una liberalidad, sin una intención de inducir un acto contrario al deber de representación de la voluntad del Estado. No es la liberalidad lo que genera la problemática, sino la falta de disposición de la voluntad estatal por parte del funcionario público. Así, existen tres posibilidades:

1. Entender que se trata de hipótesis coactivas menos intensas que la "exacción ilegal" (art. 241) en hipótesis del funcionario público, aunque por su neutralidad en la perspectiva del funcionario público no reciben aplicación. Esta posibilidad de interpretación, responde a la lógica de que las hipótesis neutras no dan cuenta de la idoneidad de la conducta para afectar el correcto funcionamiento de la administración estatal, en tanto el funcionario no se ve enfrentado a tener que desviar la función pública (y no representar la voluntad del Estado). El problema, sin embargo, es que en el caso del cohecho - a diferencia de la exacción ilegal - considera punible la conducta del privado que, en estricto rigor, es una víctima de la coacción. ${ }^{125}$

2. La segunda alternativa es comprender este cohecho neutro, como una especie de coaptación del funcionario o venta de la posición, en atención a sus funciones y caracterizados por el ejercicio del mandato estatal (parecido al cohecho en razón del cargo).

3. La tercera posibilidad, es entender que se trata de hipótesis de acuerdos ilícitos diferentes a los comprendidos en el art. 248 bis y 249 y que, en esencial, son caracterizados como deslealtades a la voluntad estatal que no implican desviación de funciones.

Del análisis de la literatura nacional, pareciera ser que "de lege lata" la última de las hipótesis es la más aceptada y correcta dogmáticamente, como se verá.

De algún modo, más o menos objetivo, la explicación del delito de cohecho del art. 248, si se considera como relevante la variante penológica, resulta ser más reprobable desde la perspectiva del funcionario público que la del art. 241 (exacción ilegal). ${ }^{126}$ En efecto, si se analizan los elementos objetivos en la hipótesis del art. 241 la conducta se caracteriza porque el funcionario público "exige coactivamente" (si y sólo si, de lo contrario...) $)^{127}$ o al menos sin alcanzar la coacción si "impone o engaña", exigiendo el pago de una ventaja o mayores derechos. Por el contario, en la hipótesis del art. 248 la solicitud es menos intensa y no se expresa de manera coactiva en sentido fuerte, al punto que se concreta en un acuerdo de características sinalagmático (si y sólo si). ¿Qué

\footnotetext{
125 Al respecto véase ARTAZA, "La utilidad del concepto...", cit. nota $n^{\circ} 5$, p. 334. (con amplias referencias en opiniones de la literatura extranjera).

${ }^{126}$ OLIVER, Guillermo, "Incoherencia y Vacíos en la regulación del delito de Cohecho", en: Revista de Doctrina y Jurisprudencia, $\mathrm{N}^{\circ}$, Thomson Reuters, Año 3, año 2012, pp. 30-50, pp. 31 y s. Este autor sostiene que aquella desproporción penológica es consecuencia de un error del legislador que en la reforma de 2009 (Ley N²0.341) no habría respetado el criterio establecido en la Ley $\mathrm{N}^{\circ} 19.645$ de 1999.

${ }^{127}$ La dogmática chilena moderna exige en la hipótesis del art. 241 ya sea "imposición" o "engaño"; véase en RODRÍGUEZ /OSSANDÓN, Delitos contra la función pública, cit. nota n5, p. 432.
} 
explica que la hipótesis, en principio, más grave por su intensidad coactiva (art. 241) reciba una pena menos intensa? Probablemente, y más allá de atribuirle un posible error al legislador, ${ }^{128}$ aquello encuentra su razonabilidad en algún grado de idoneidad distorsionadora de la función pública que está detrás del acuerdo ilícito y que no se expresa en la mera exacción ilegal y su más intensa conducta ( de "imposición y el engaño"). ${ }^{129}$ Para responder a aquello, habría que contestar a la interrogante ¿Existe algún caso de deslealtad al Estado, que no se exprese necesariamente en una desviación concreta de la función?

Solicitar derechos o beneficios económicos a cambio de un "acto propio del cargo", expresa objetivamente una negociación y acuerdo de dos voluntades de carácter ilícito, aunque todavía no sea una expresión concreta de desviación o deslealtad funcional que se desarrolle en el "ámbito de protección de la norma". En principio, las exigencias típicas relativas al tipo de acto en el art. $248 \mathrm{CP}$ - si se las compara con las del delito de cohecho "propio" del art. 248 bis - limitan aún más las expresiones de deslealtad. En el caso del art. 248 se refiere al "acto propio del cargo" - esto es, a actos de la competencia específica del funcionario ${ }^{130}$ - mientras que el art. 248 bis referido a "un acto con infracción a los deberes de su cargo", lo que debería expresar un desvalor aún más alto (si es que se entiende como un delito agravado). La literatura chilena clásica no ha acentuado aquella "infracción de deberes" con un aspecto funcional que explica esa mayor cualificación y se ha limitado a señalar que es más grave y se refiere a las funciones propias del cargo o del servicio al que pertenece el empleado y su infracción abarca infracciones a reglamentos, instructivos, circulares, etc., aunque podría presentarse en actividades discrecionales. ${ }^{131}$ Las razones de esa extraña explicación (sui generis) radican en que la diferencia sistemática normalmente acentuada por la literatura es la más lógica (para omitir un acto propio del cargo o solicitar más derechos) y no la excepcional aquí analizada (para ejecutar un acto propio del cargo) o del delito consumado por el acuerdo ilícito. Etcheberry, por ejemplo, sostiene que la diferencia sustancial entre la figura de cohecho propio e impropio - cuestión repetida por Rodríguez/Ossandón - es que en el cohecho propio el empleado se hace pagar para cumplir con su deber (perspectiva del funcionario público), mientras que en el impropio se hace pagar para faltar a sus obligaciones. ${ }^{132}$ Esta perspectiva, absolutamente explicable bajo el modelo regulatorio del acuerdo ilícito exigido típicamente para la consumación - y que veía la conducta del particular sólo como una mera inducción - no da cuenta de la figura autónoma a que hacemos referencia aquí. Aquella explicación ha

\footnotetext{
${ }^{128}$ En este sentido OLIVER, "Incoherencia...", p. 31 y s.

129 Pena del delito del art. 241: "será sancionado con inhabilitación absoluta temporal para cargos u oficios públicos en cualquiera de sus grados y multa del duplo al cuádruplo de los derechos o del beneficio obtenido"; pena del delito del art. 248: "será sancionado con la pena de reclusión menor en su grado mínimo, suspensión en cualquiera de sus grados y multa de la mitad al tanto de los derechos o del beneficio solicitados o aceptados"; pena del delito del art. 250/248 "Tratándose del beneficio ofrecido en relación con las acciones u omisiones del artículo 248, el sobornante será sancionado, además, con la pena de reclusión menor en su grado mínimo."

${ }^{130}$ RODRIGUEZ/OSSANDON, Delitos contra la función pública, cit. nota n5, p. 325: "Sin embargo, creemos que en Chile sólo la concepción restrictiva resulta defendible, atendida la regulación del cohecho contenida en nuestro Código Penal, cuyas disposiciones pertinentes aluden a actos propios del cargo. No puede sostenerse seriamente que sean actos propios del cargo de un funcionario aquellos que no pertenezcan a la competencia de éste, pero cuya realización pueda verse facilitada por su calidad de tal." (también con mayor profundidad p. 338)

${ }^{131}$ RODRIGUEZ/OSSANDON, Delitos contra la función pública, cit. nota ${ }^{\circ} 5$, p. 342; ETCHEBERRY, Derecho penal, cit. nota ${ }^{\circ} 53$, p. 255

${ }^{132}$ ETCHEBERRY, Derecho penal, cit. nota n53, p. 255
} 
quedado, por lo tanto, parcialmente obsoleta y resulta necesario buscar alternativas de expresión de la desviación funcionarial o deslealtad a la voluntad del Estado.

La solución, sin embargo, está en la identificación gradual de hipótesis de distorsión funcional. Si se reconoce que existen "actos del cargo" que no necesariamente asumen su expresión de deslealtad a la voluntad del Estado por su negativa o condicionamiento a realizarlo ni tampoco por la obstrucción - ocultación, desfiguración o desviación - de la función, sino en el abuso grave de los procedimientos legales utilizados en favor de un interés particular (como en hipótesis de retraso grave) ${ }^{133}$ o porque su realización no está justificada por sí misma (sino, sólo por la intervención del sobornador), se puede reconocer también un grado, aunque menor, pero existente de un acuerdo - más o menos sinalagmático - con idoneidad distorsionadora de la función pública. Esta tesis, permite resolver la posible hipótesis de neutralidad del acto final del cargo, otorgándole al menos un ámbito de relevancia típica ( $\operatorname{cin}$ necesidad de excluirla absolutamente). Hipótesis ejemplificadoras son discutidas en la literatura española en relación al art. 420 CP español (cohecho impropio) e incluyen constelaciones como la denominada "agilización" de una diligencia concreta o hipótesis muy graves de favoritismo que, en concreto no constituyen un acto de desviación, aunque si uno de facilitación y hace más eficiente el acto del cargo. ${ }^{134}$ Una caso ejemplificador es el conocido por el $7^{\circ}$ Juzgado de Garantía de Santiago (RIT 1.127-2008 - RUC 0700774529-4) y en que un policía solicitó dinero a un particular para tramitar una orden de investigar y agilizar una orden de arresto, actos que siendo propios del cargo, tienen evidentemente una cualidad distorsionadora de la función. ${ }^{135}$ La única limitación, y que será tratada más abajo, es la relativa a la exigencia típica de tratarse de la "ejecución de un acto propio del cargo" y no del "ejercicio del cargo" que podría abarcar constelaciones más amplias.

Estas hipótesis, si bien gradualmente son menos intensas que aquellas incluidas en el art. 248 bis CP, sin embargo, son esencialmente más graves e intensas desde la perspectiva funcional que los actos neutros del cargo y que no manifiestan la contracara ilícita del acuerdo ilícito, que podrían ser incluidos. ${ }^{136}$

A conclusiones similares, en nuestro país, han llegado autores como Artaza o Rodríguez/Ossandón. Estos expresan, de formas distintas a la planteada aquí, que el elemento "para o por" (contrapartida del cohecho del art. 248) debe dar cuenta siempre de infracciones a deberes que manifiestan formas distintas de ataques a la administración del Estado y coherentes con la desvaloración de las mismas. Artaza, a modo de ejemplo, interpreta - siendo coherente con la lógica contractual del injusto -

\footnotetext{
${ }^{133}$ Acepta este tipo de hipótesis también KINDHÄUSER, "Presupuestos...", cit. nota n50, p.9.

134 VAZQUEZ-PORTOMEÑE (Fernando, "Sobre el cohecho por "actos propios del cargo" y sus relaciones con el delito de exacciones ilegales", en: Cuadernos de Política Criminal, Número 116, II, Época II, septiembre 2015, pp. 121-157, p. 125), señala que "lo más razonable es pensar que el legislador se ha percatado de la compleja relación existente entre el cohecho de facilitación y el bien jurídico de los delitos de corrupción, optando por limitar la intervención penal a los casos en que, al aceptarse la ventaja o promesa ofrecidas por el particular, este "engrasa" de manera efectiva la actividad administrativa. Con arreglo a este punto de vista, las conductas unilaterales, de mera oferta, no presentan todavía el suficiente grado de peligrosidad (objetiva y subjetiva). En su impunidad no puede ni debe verse, en consecuencia, un vacío legal denunciable." Algunos ejemplos en la p. 133.

135 Véase más antecedentes en BALMACEDA H., Gustavo, Los Delitos Funcionariales, en la Jurisprudencia, LegalPublishing-Thomson Reuters, 2013, Santiago, p.442.

${ }_{136}$ Opinión parecida, aunque en enfrentando un problema sistemático distinto, véase en VAZQUEZPORTOMEÑE, "Sobre el cohecho...", cit. nota n' 134, p. 133.
} 
que la infracción a deberes de referencia de los arts. 248 y 250 CP sólo puede ser entendida en su sentido valorativo si "el agente ha actuado con infracción de sus deberes como representante en el marco de su relación con terceros, abusando de su poder decisorio concreto o específico emanado de su esfera de atribuciones, ya sea priorizando intereses incompatibles (beneficio propio) para condicionar su actividad. Este autor, siguiendo la tesis de Viganó en Italia, sostiene que es posible justificar la sanción cuando el particular cede a la solicitud del funcionario con el único propósito de obtener una ventaja indebida, como por ejemplo "ver mejorada su situación en relación al resto de los ciudadanos, y no con el propósito de evitar un daño injusto". ${ }^{137}$

La mera liberalidad, o la recompensa genérica a cambio de una tendencia difusa y favorable a los intereses particulares - que estaría presente en la constelación analizada en este trabajo relativa al financiamiento parlamentario - así como también, en el otro extremo, casos en que el particular resulta ser coaccionado o forzado ilícitamente a dar dinero a cambio de un acto neutro del cargo, no resultan ser constelaciones abarcadas por el tipo penal de cohecho de los art. 248/250 y 250/248. Así la cosas, no existe ninguna hipótesis típica entre nosotros que pueda acoger la constelación neutra de un financiamiento político sin desviación de funciones o sin deslealtad a un mandato, que es precisamente un presupuesto formal para la comprensión del delito de cohecho parlamentario, si se considera que en funciones políticas y legislativas no puede conceptualmente aceptarse una desviación.

Un segundo punto de extrema relevancia para los fines propuestos en este artículo, dice relación con que las imputaciones a particulares y parlamentarios desarrolladas por el Ministerio Público en el marco del financiamiento irregular de campañas políticas tienen como característica común que dicho financiamiento sería parte de un acuerdo ilícito que no tendría como contraprestación de los parlamentarios un "acto legislativo concreto" (como podría ser una votación favorable en un proyecto concreto). La contracara injusta estaría caracterizada sólo de una "actitud o tendencia favorable a los intereses del sector" [Aquello, es lo que en Alemania se le ha denominado "Klimapflege" (clima favorable) o "Anfüttern" (alimentación)]. Este punto, sin embargo, resulta ser el único en que correctamente tanto la literatura mayoritaria y la jurisprudencia coinciden completamente, en un doble sentido: Primero, en que el acto del cargo sólo puede referirse a "deberes propios" del sujeto y; segundo, en el sentido que la exigencia típica no permitiría un acuerdo futuro generalizante o la aceptación de "una mera actitud positiva frente a ciertos intereses", esto es, que no tuviera su objeto determinado y claro.

Rodríguez/Ossandón han sostenido correctamente que la tesis amplia desarrollada en España no es compatible con los tipos penales chilenos, en dos sentidos. Primero, en que las disposiciones nacionales aluden a deberes del cargo o a deberes propios del cargo, lo que excluiría a aquellos que sólo se verían facilitados por el cargo. ${ }^{138}$ Segundo, en que el tipo penal chileno se refiere expresamente a "un acto del cargo" (a diferencia del más amplio "ejercicio de funciones del cargo" del derecho alemán), lo que significa concretamente la exigencia de un objeto concreto de referencia objetiva/subjetiva. Esta tesis ya ha sido aceptada por un voto de minoría en sentencia de la Corte Suprema

\footnotetext{
${ }^{137}$ ARTAZA, “La utilidad del concepto...”, cit. nota n5, p. 334 y s.

${ }^{138}$ RODRIGUEZ/OSSANDÓN, Delitos contra la función pública, cit. nota n 5 , p. 338.
} 
(Sentencia Rol No 20063/2016, Tribunal Pleno, 4 de mayo de 2016) en la causa contra el Senador Orpis, en que en el considerando "décimo Tercero" número $8^{\circ}$ sostuvo que:

\begin{abstract}
" $8^{\circ}(\ldots)$ enseguida, en cuanto la intervención del senador O. de haber votado leyes aplicables a dicha empresa, de tal conducta parlamentaria no se desprenden antecedentes suficientes para colegir - aún por vía de presunciones - que hubo de parte del senador $\mathrm{O}$. una oferta determinada a cambio del aporte económico que admita la calificación de una solicitud o aceptación del soborno, acto malicioso propio del incumplimiento de los deberes del cargo con favorecimiento para dicha empresa, tal como en forma precisa lo requieren las disposiciones penales antes analizadas que exigen dolo directo en el aspecto subjetivo del tipo."
\end{abstract}

Se podrían relativizar las conclusiones arribadas anteriormente, utilizando el argumento de que la incorporación de hipótesis de delito de cohecho "subsiguiente" (art. 250 en relación a arts. 248 y 248 bis) - esto es, por abarcar hipótesis de conductas del pasado ("por haber ejecutado u omitido...") - refuerzan la idea de mera sanción de la vulneración de deberes de probidad; o, al menos, que no tienen efecto de desviar la función pública. La literatura ha llegado a sostener que las únicas razones para incluir estas hipótesis son la criminalización de las sospechas (delito de sospecha) y/o la facilitación de la prueba y sanción de pactos previos. ${ }^{139}$ Esta premisa se basa en la siguiente lógica: "nadie va a pagar por algo que ya recibió y por lo que en su momento no tuvo que pagar". ${ }^{140}$ Navarro Cardoso, sostiene que estas hipótesis, a "falta de un estudio en profundidad", permitirían "hacer frente al lucro ilícito del empleado público, poniendo en peligro la integridad de la función pública". ${ }^{141}$ Con esto, ubica en el centro de la valoración el ethos de la función pública y no la función pública en sí misma. Oliver, abandonando su propuesta de configuración de bien jurídico y de la lesividad del cohecho, acepta que estas conductas sean legítimamente criminalizadas en la medida que comprendan la mera negociación sobre la función pública, aplicando asistemáticamente los mismos postulados elaborados para el cohecho antecedente. ${ }^{142}$

En realidad, estas hipótesis en el marco del modelo del "acuerdo ilícito" como referencia, tienen un objetivo mucho más modesto que el explicado más arriba; esto es, sólo buscan cubrir constelaciones de negocios sobre la función pública, no cubiertos por el cohecho antecedente, pero que tienen el mismo objeto ilícito. Se trata, entonces, de hipótesis de otorgamiento de una mera prestación fundada en la omisión de un acto del cargo o en la ejecución contraria al deber, cuyo acuerdo se ha iniciado sin exigir una contraprestación del particular y que se ha transformado en negocio, luego de culminado el "favor", ya sea por solicitud del funcionario u ofrecimiento del particular.

\footnotetext{
${ }^{139}$ Un análisis en la literatura chilena sobre las opiniones de la dogmática española véase OLIVER, “Aproximación...", cit. nota n5, p. 100

140 NAVARRO CARDOSO, Fernando, "Cohecho pasivo subsiguiente o por recompensa", en: Revista Electrónica de Ciencia Penal y Criminología (RECPC), 18-25 (2016), p. 15.

${ }^{141}$ NAVARRO CARDOSO, cit. nota ${ }^{\circ} 135$, p. 15.

142 OLIVER, “Aproximación...", cit. nota ${ }^{\circ} 5$, p. 100. "Si -como ya lo hemos señalado más de una vezel bien jurídico protegido en el delito de cohecho es el correcto servicio que la Administración presta a los ciudadanos, lo que se traduce en la exigencia de que no se les pida que paguen por el servicio, ni que tampoco se acepten los eventuales beneficios económicos que los ciudadanos puedan ofrecer por él, o en caso de que el servicio no sea gratuito, que no se les pida que paguen más que lo que se encuentra establecido en el propio ordenamiento jurídico, ni que tampoco se acepten los eventuales beneficios económicos que puedan ofrecer por sobre el monto fijado, entonces el cohecho subsiguiente del funcionario público sí atenta contra el bien jurídico, lesionándolo".
} 
Lo importante, en todo caso, es que al igual que el cohecho antecedente, tanto el cohecho activo como el pasivo subsiguiente se construyen sobre la desvaloración de la negociación del cumplimiento del deber sobre el cual se configura la función pública a favor del ciudadano. Aquello se traduce en que el objeto de la solicitud/aceptación del funcionario público u ofrecimiento/consentimiento del particular es la transacción de un acto del cargo a cambio de beneficio económico, que previamente ha implicado una "desviación de funciones", ya sea por la omisión de un acto del cargo o infracción de deberes. De las combinaciones entre el art. 250 y los arts. 248 y 248 bis CP, surgen problemas similares a los del cohecho antecedente, aunque solucionables de la misma forma que el cohecho antecedente.

\subsection{Análisis de "lege ferenda" del proyecto de Ley (Boletín $\left.\mathrm{N}^{\circ} 10.739\right)$ :}

Como ya se adelantó, el Congreso Nacional se encuentra estudiando la propuesta del gobierno de reformar la figura del cohecho del funcionario público del art. $248 \mathrm{CP}$, adoptando la llamada figura "cohecho en razón del cargo" y que elimina el elemento subjetivo trascendente del tipo penal que definía el objeto de la solicitud del funcionario público (solicitar y aceptar). En la línea sustantiva ya analizada más arriba, esta modificación dejaría de expresar - al menos, en la subjetividad de la conducta - la orientación al acuerdo ilícito como modo de deslealtad a la institución. Sin perjuicio de lo anterior, no hay razones para llegar tan lejos y utilizar el derecho penal como mera herramienta de reforzamiento de los valores éticos de la función pública. En realidad, aquél cercenamiento práctico de elementos típicos, no debe ser interpretado como un cambio de modelo. El tipo penal así configurado, lo que busca es sencillamente tanto simplificar la prueba de ciertas constelaciones complejas de cohecho como abarcar acuerdos ilícitos "de ejecución diferida de servicios" con adelantamiento del pago, entre sobornante y sobornado. Esta especie de venta de la posición, para servicios futuros, representa también - en el sentido teleológico exigido por Schünemann ${ }^{143}$ - una especie de contrapartida: en sentido puro el "pasarse para el otro lado". El funcionario público se pone a disposición del corruptor "para cualquiera eventualidad en que se pudiere tener necesidad de su intervención", ${ }^{144}$ aun cuando no sea necesario determinarla expresamente. Ya que el ofrecimiento es general y la contrapartida no se encuentra exigida concretamente, esta debe expresarse a lo menos potencialmente, en el sentido explicado por Vázquez- Portomeñe; ${ }^{145}$ se deberá exigir un contexto objetivo determinado y un nivel de conocimiento del contexto que permita imputar una deslealtad a la norma de conducta que "prohíbe comercializar la función pública". Una opción contraria, podría significar simplemente la penalización de presunciones de derecho, incompatibles con un derecho penal de un estado de derecho ${ }^{146}$.

En otras palabras, objetivamente el contexto de ofrecimiento o solicitud de un beneficio deberá ser el de un ámbito en que sea posible una manifestación de deslealtad a la voluntad estatal o de posible desvío de funciones en favor de un particular. De ahí que, el elemento "empleado público" se alce como esencial y que concretamente se trate de un titular de un cargo público susceptible de ejercer facultades en favor del particular. Dicho de otra forma: debe existir pendientes gestiones potenciales en favor del privado susceptibles de manifestar deslealtad o desviación institucional. Sólo aquel contexto

\footnotetext{
${ }^{143}$ SCHÜNEMANN, "Die Unrechtsvereinbarung...”, cit nota ${ }^{\circ} 61$, p. 791.

${ }^{144}$ MILITELLO, cit nota ${ }^{\circ} 73$, p. 246.

${ }^{145}$ VÁZQUEZ- PORTOMEÑE, cit nota n ${ }^{\circ} 74$, p. 134.

${ }^{146}$ Con mayores detalles, KINDHÄUSER, "Presupuestos...", cit. nota n50, p. 10.
} 
podrá servir de expresión fáctica suficiente como para atribuir al sujeto una venta de la posición como deslealtad a la norma de prohibición y no una mera infracción administrativa. El dolo debe cubrir, en ese sentido, el contexto inequívocamente transaccional que manifiesta una concreta falta de "independencia".

Sólo en parte aquello es reconocido en la propia propuesta del ejecutivo que incluye un art. 251 sexies que excluye dar u ofrecer donativos oficiales o protocolares, o aquellos de escaso valor económico que autoriza la costumbre como manifestaciones de cortesía y buena educación. Aquello, si se sigue esta perspectiva valorativa, no puede ser entendido únicamente como la exclusión de casos de bagatela - falta de necesidad o merecimiento de pena por su falta de gravedad - , sino también de una falta de expresión material de una especie genérica de "deslealtad institucional".

\section{5. Ámbito de protección, injusto del cohecho y la vulneración de deberes administrativos de probidad de los parlamentarios (perspectiva normativa del análisis)}

Como ya se ha analizado, el tipo penal de "cohecho" ha definido históricamente un ámbito de protección amplio, pero con límites definidos, y un injusto basado en la vulneración de la prohibición de "negociar" los actos de un cargo público en desviación de la voluntad estatal, cuyas condiciones habían sido garantizadas institucionalmente. Stuart Green sostiene que para el modelo del acuerdo ilícito la mera vulneración de los deberes de probidad referida a la obtención de regalos, no coincide con el injusto del delito de cohecho: "los sobornos implican el acuerdo de dar algo de valor a cambio de influir en la toma de decisiones o acciones, mientras que los regalos, propinas o contribuciones a campañas políticas no implican un acuerdo de ese tipo". ${ }^{147}$ Adicionalmente, este autor sostiene que los tipos de deslealtad "per se" a que se refiere el cohecho - a diferencia de lo que nosotros en este trabajo hemos denominado mera ilicitud moral - consisten no sólo en la vulneración de deberes morales y legales de probidad, sino esencialmente requieren que el agente se "pase al otro lado", esto es, favorezca los intereses de alguien distinto a aquél respecto del cual se tenga un deber de lealtad. Esto implica que la venta del acto del cargo neutro, para hacer lo que ex ante se sabe que correspondía funcionalmente - o lo que correspondía en beneficio del "principal" - sólo puede vulnerar ciertas normas de probidad, pero no puede ser entendido como una deslealtad a la voluntad estatal en el sentido del cohecho ya no expresa algún grado de desviación o deslealtad al deber de representación. Incluso, aquellas hipótesis del derecho comparado - aunque en examen por el legislador chileno - de cohecho "en razón del cargo" exigen un grado objetivo de aquél "pasarse para el otro lado", por lo que aparece como insuficiente la mera vulneración a una norma de probidad que prohíbe recibir meras liberalidades.

Dos criterios se han obtenido del análisis de este artículo y pueden servir de guía para el trabajo dogmático: primero, que la mera infracción de deberes que vincula al funcionario y Estado son incapaces por si solos de manifestar todo el injusto del delito de cohecho y; segundo, que los deberes de relevancia jurídico penal - en un contexto de fragmentariedad del derecho penal - son aquellos que mantienen una relación de

${ }^{147}$ GREEN, Mentir, cit. nota n42, p. 263. 
funcionalidad con el bien jurídico. ${ }^{148}$ Aquello, coincide con una línea jurisprudencial [representada en la sentencia de la Segunda Sala de la Exc. Corte Suprema en causa Rol $\mathrm{N}^{\circ} 97657$ de 4 de diciembre de 2012 (Caso EFE)] que ha sostenido que la frase "con infracción a los deberes de su cargo", se refiere a la contradicción de las disposiciones que regulan el desarrollo de las funciones propias del cargo o del servicio al que pertenece y estas - sea una actividad reglada o discrecional- importa una desviación o un exceso del poder que se le ha conferido".

Desde una perspectiva fragmentaria - esto es, que intente identificar el tipo y contenido de la norma de conducta cuya validez protege excepcionalmente el derecho penal así como el ámbito de protección de la norma penal del cohecho - se hace pertinente distinguir los distintos tipos de vulneraciones normativas por parte de sujetos activos [deberes]. Por lo mismo, en términos amplios y atendiendo a su contenido normativo, es posible distinguir 1) deberes de gestión institucional; 2) deberes de "flanqueo" a la funcionalidad y; 3) deberes "profilácticos" de los intereses estatales, radicados en formalidades o principios de probidad y transparencia facilitadores del control.

La importancia y rendimiento de esta distinción radica en que permite reconocer específicamente la norma de conducta vulnerada y que fundamenta el injusto típico de entre un amplio grupo de deberes. En efecto, permite explicar las razones de porque el injusto penal del cohecho, no coincide - o al menos no únicamente - con cualquier infracción a las normas de mero "flanqueo" o "profilácticas" de probidad, como aquellas que regulan la transparencia o la aceptación de regalos por parte de funcionarios públicos que, además, sólo son dirigidas a estos y no a los particulares.

El primer grupo de deberes (1) dicen relación con aquellos que surgen de las normas de conducta generales y específicas que regulan y guían el ejercicio funcional, que se expresa en el objeto del mandato estatal al funcionario y respecto del cual este tiene un deber de representar la voluntad; esto es, se refiere a los deberes que guían funcionalmente el actuar de los empleados públicos relativos a la gestión de una política o interés o administración de recursos. De esta naturaleza de normas corresponde, a modo de ejemplo, el art. 61 letra b de la Ley $\mathrm{N}^{\circ} 18.834$ (Estatuto Administrativo) (del Título III, "De las Obligaciones Funcionarias", párrafo $1^{\circ}$ ), al señalar como deber general de todo empleado público "b) Orientar el desarrollo de sus funciones al cumplimiento de los objetivos de la institución y a la mejor prestación de los servicios que a ésta correspondan”. De carácter general son también aquellos deberes que emanan del art. $62 \mathrm{~N}^{\circ} 8$ de la Ley Orgánica de Bases Generales de la Administración del Estado (LOCBGAE) que prohíbe contravenir los deberes de eficiencia, eficacia y legalidad que rigen el desempeño de los cargos públicos, con grave entorpecimiento del servicio o del ejercicio de los derechos ciudadanos ante la Administración. En términos específicos,

\footnotetext{
${ }^{148}$ En el mismo sentido véase DE LA MATA BARRANCO, Norberto, "El bien jurídico protegido en el delito de cohecho. La necesidad de definir el interés merecedor y necesitado de tutela en cada una de las conductas típicas encuadradas en lo que se conoce, demasiado genéricamente, como ámbito de la corrupción, en: Revista de Derecho Penal y Criminología, 2.a Época, ํㅜ 17 (2006), pp. 96. y ss. Este autor habla acertadamente de "El deber del funcionario, (...) no es un interés penal per se, sino presupuesto instrumental de protección del verdadero interés jurídico-penal, la función que él desarrolla en beneficio de los administrados. Parece acertado, (...) que el injusto descanse en la lesión de la relación funcionarial y cifrándolo en el correcto ejercicio de la función pública, siempre desde la perspectiva de los ciudadanos, frente a los cuales el deber de la Administración y de sus órganos operativos físicos —los funcionarios - cobra auténtica relevancia penal" (p. 98)
} 
sin embargo, la actuación de cada funcionario público dependerá de la ley que regule cada función (y más específicamente aún de las órdenes formales de sus superiores jerárquicos). De esta naturaleza, aunque como norma específica, es la del art. 45 de la Ley 21.000 (Comisión para el Mercado Financiero) que regula el proceder del Fiscal de la Comisión al constatar alguna posible infracción a la normativa; o la norma del art. 56 de la Ley Orgánica de Municipalidades que establece que al alcalde le corresponderá la dirección y administración superior y la supervigilancia del funcionamiento de la Municipalidad. Una infracción a este tipo de normas que vinculan el acto del cargo y el cumplimiento del deber con una función institucional concreta, aun cuando resulta ser relevante para el injusto del cohecho, no alcanza a fundar por si misma el desvalor de dicho delito. Este grupo de deberes son aquellos que en el delito de cohecho están relacionados con el "acto propio del cargo"" o el "cumplimiento de sus deberes", esto es, con la función delegada desde el "principal” (Estado) al funcionario.

Un segundo grupo (2) de normas son las que, en términos genéricos podemos denominar de flanqueo y vinculados al principio de probidad. Aquí, es posible identificar dos subgrupos: (2.i) normas prohibitivas que protegen la funcionalidad de la administración pública y; (2.ii) normas de probidad dirigidas a la integridad moral del funcionario.

Al primer subgrupo (2.i) pertenecen aquellas normas de conducta prohibitiva concreta, dirigida a funcionarios públicos y/o a los privados que se relacionan con el Estado que, con el objetivo de proteger la funcionalidad de la administración pública - relacionada con los intereses de los ciudadanos -, intentan impedir actos de deslealtad de los encargados de cumplir el mandato institucional. A este grupo de normas pertenece aquella que prohíbe negociar la ejecución de la función pública al empleado público que tenga por objeto la priorización del primero de los intereses privados o falsificación de la voluntad del Estado entregada al funcionario (deducido del art. 248 y ss. CP). ${ }^{149}$ También pertenece el art. $62 \mathrm{~N}^{\circ} 5$ de la LOCBGAE que prohíbe solicitar, hacerse prometer o aceptar, en razón del cargo o función, para sí o para terceros, donativos, ventajas o privilegios de cualquier naturaleza o; el $\mathrm{N}^{\circ} 6$ del mismo artículo que prohíbe intervenir, en razón de las funciones, en asuntos en que se tenga interés personal o sus parientes. Aun cuando está dirigida esta vez a los ciudadanos, a este grupo pertenece también la norma de conducta deducida de la norma de sanción penal del art. 250, que prohíbe incentivar la negociación de la gestión o ejecución de la función pública por medio del ofrecimiento de beneficio económico.

Un segundo subgrupo de probidad (2.ii) es aquél que, al igual que el anterior subgrupo, intentan configurar una especie de flanqueo sobre la institución, pero no están referidos directamente a la función concreta ni a la gestión de políticas o administración de bienes públicos, sino que a la "integridad moral" del funcionario o empleado público; esto es, como lo dispone el art. 52, inc. $2^{\circ}$ LOCBGAE, se trata de un mandato de "observar una conducta funcionaria intachable y un desempeño honesto y leal de la función o cargo, con preeminencia del interés general sobre el particular". Se trata de reglas que establecen un marco que define la actitud moral que los funcionarios públicos deben observar al momento de ejercer sus funciones. A este grupo de deberes corresponden las normas de probidad del art. 84 letras g) del Estatuto Administrativo (prohibición de ejecutar actividades, ocupar tiempo de la jornada de trabajo o utilizar personal, material

${ }^{149}$ ARTAZA, "La utilidad del concepto...”, cit. nota n5, p. 316. 
o información reservada o confidencial del organismo para fines ajenos a los institucionales) o la letra h) (prohibición de realizar cualquier actividad política dentro de la Administración del Estado).

A este grupo de normas pertenece, por ejemplo, el art. 5 letra A. de la Ley Orgánica del Congreso Nacional, Ley $\mathrm{N}^{\circ} 20.979$ (LOCCN), que mandata a diputados y senadores a ejercer sus funciones con pleno respeto de los principios de probidad y transparencia, en los términos que señalan la Constitución Política, la Ley Orgánica Constitucional y los reglamentos de ambas Cámaras. En particular, el principio de probidad en materia parlamentaria, consiste en observar una conducta parlamentaria intachable y un desempeño honesto y leal de la función, con preeminencia del interés general sobre el particular. A diferencia de las normas anteriores, en este caso, la función concreta que es protegida no está relacionada con el cumplimiento leal de un mandato delegado por el Estado exclusivamente, sino esencialmente a la naturaleza de la función parlamentaria orientada al bien común.

Al tercer grupo (3) pertenecen las normas "profilácticas", esto es, aquellas que establecen deberes informativos sobre los cuales es posible diseñar políticas de control administrativo y judicial. De este tipo de normas son la Ley del Reglamento de los Registros de Agenda Pública y de Lobistas, la Ley de Lobby $\mathrm{N}^{\circ} 20.730$ de 2014, el Decreto $\mathrm{N}^{\circ} 71$ que regula el lobby y las gestiones que representen intereses particulares ante las autoridades y funcionarios de la administración del estado y el Reglamento de Gestores de Intereses Particulares del Senado de 26 de noviembre de 2014. Así, por ejemplo, el art. 17 del Reglamento del lobby Senado, establece el deber a los sujetos pasivos de la obligación de informar al Registro de Donativos, en el plazo máximo de diez días hábiles, los donativos que reciban cuyo valor exceda de una unidad tributaria mensual. También los deberes informativos que surgen de la Ley $\mathrm{N}^{\circ} 20.880$ y de su reglamento (Decreto $\mathrm{N}^{\circ} 2$ del Ministerio Secretaría General de la Presidencia) sobre probidad en la función pública y prevención de los conflictos de intereses y que en su art. $2 \mathrm{~N}^{\circ} 13$ exige a parlamentarios efectuar declaración de intereses y patrimonio.

Los tipos penales de los arts. $248 \mathrm{CP}$ y ss., fragmentariamente han seleccionado sólo una norma de conducta - dentro de amplio grupo de normas prohibitivas que protegen la funcionalidad de la administración pública - para que su validez sea protegida penalmente. Lo anterior tiene la capacidad de proteger la funcionalidad institucional y confianza en el funcionamiento institucional de todos los ámbitos de la administración del Estado, en tanto aquella norma de conducta prohibitiva es, a su vez, una norma que protege la "voluntad estatal" (o el diseño funcional de la ley) expresada en normas que regulan las funciones estatales [primer grupo (1)] y que han sido delegadas a ciertos "agentes".

Se trata, entonces, sólo de la captación por los arts. 248 CP y ss. de un modo conductual de aquellos comprendidos en el amplio grupo de prohibiciones de la deslealtad [(subgrupo (2. i)] al mandato estatal [determinados deberes del grupo (1)]. Otras expresiones de deslealtad no se encuentran protegidas por el derecho penal (sólo por el derecho administrativo disciplinario) o se encuentran abarcadas por otros tipos penales como la infidelidad en la custodia de documentos (arts. 242 y ss.), violación de secretos (arts. 246 y ss.), la exacción ilegal (art. 241) o la negociación incompatible (Art. 240). La deslealtad al mandato estatal manifestado por la infracción a estos deberes relevantes 
para el cohecho, es sólo la de más relevancia: prohibición de la comercializar de la voluntad estatal o la función delegada.

La norma de conducta dirigida a funcionarios públicos a cargo de cumplir el mandato estatal y cuya validez es protegida por los arts. $248 \mathrm{CP}$ y ss., consiste sólo en la prohibición de comercializar la voluntad estatal o la función mandatada estatalmente [subgrupo (2.i)] que tiene como objeto una conducta de falsedad de la voluntad estatal o de desviación de funciones, que se expresa de dos formas: desviaciones de contenido y de oportunidad. Estas manifestaciones de la voluntad estatal - en sentido amplio - o funciones delegadas son vulneraciones a los deberes que constituyen el primer grupo de normas [grupo (1), deberes de gestión institucional]. No es necesario recurrir a la complementación de normas de probidad que se orienten al reforzamiento de la "integridad moral" del funcionario, en tanto la naturaleza de estos deberes y determinación de las funciones se bastan a sí mismos (ejemplo, la objetividad). Sin perjuicio de lo anterior, puede ser necesario la complementación con deberes funcionariales generales, como el deber de objetividad en funciones que exijan decisiones discrecionales, en tanto la expectativa normativa (que configura el bien jurídico "confianza institucionalizada") tiene como fuente este deber.

\begin{tabular}{|c|c|}
\hline $\begin{array}{l}\text { Norma de Conducta prohibitiva cuya } \\
\text { validez reclama el derecho penal } \\
\text { [Seleccionada del subgrupo (i)] }\end{array}$ & $\begin{array}{l}\text { Objeto de la comercialización } \\
\text { [grupo (1), deberes de gestión } \\
\text { institucional que representan la función } \\
\text { mandatada estatalmente)]. }\end{array}$ \\
\hline $\begin{array}{l}\text { Prohibición de comercializar la función } \\
\text { mandatada estatalmente } \\
-\quad \quad \text { Solicitar a cambio/aceptar a } \\
\text { cambio (si y sólo sí) } \\
-\quad \text { Ofrecer a cambio/ consentir } \\
\text { a cambio }\end{array}$ & $\begin{array}{l}\text { Deberes que guían funcionalmente el } \\
\text { actuar específico de los empleados } \\
\text { públicos relativos a la gestión de una } \\
\text { política o interés o administración de } \\
\text { recursos. } \\
\text { "acto propio de su cargo"; "acto con } \\
\text { infracción a los deberes de su cargo"; } \\
\text { "deber del cargo" }\end{array}$ \\
\hline
\end{tabular}

Por su parte, la norma de conducta dirigida a los privados, deducida de la norma de sanción penal del art. $250 \mathrm{CP}$ y cuya validez se protege penalmente, es aquella que prohíbe incentivar la negociación de la gestión o ejecución de la función pública y voluntad estatal por medio del ofrecimiento de beneficio económico.

El modelo del acuerdo ilícito en la configuración del delito de cohecho de los arts. 248 $\mathrm{CP}$ y ss. y sus vinculaciones normativas es, entonces, incompatible con la constelación de financiamiento irregular a parlamentarios y, lo que resulta más grave, con casos de "comercialización del mandato popular" o del ejercicio de la función de parlamentario; lo anterior es así, en tanto ni es este un "cargo" cuya lealtad esté vinculada con la administración estatal (dependencia) ni la administración estatal ha dispuesto, en la mayoría de los casos, una gestión administrativo-institucional que dependa de la función de parlamentario (que este deba cumplir con lealtad a la administración). Aquello explica que el principio de probidad general - dar preeminencia al interés general por sobre el interés particular - se manifiesta de manera diversa en caso de parlamentarios (art. 5 letra A de la LOCCN) y está limitado a la naturaleza de la función. Esto es así, y no podría ser de otro modo, porque ni la función representativa, política, legislativa o de control a la administración, en principio, pueden vincularse con el tipo de gestión 
administrativa de cualquier poder del Estado y que, adicionalmente, esté vinculada con la relación del Estado y ciudadanos (exigencia del bien jurídico). En otras palabras, los parlamentarios, por regla general (si excepcionalmente), no gestionan ni ejecutan políticas públicas delegadas estatalmente (por "el principal") y cuyo funcionamiento adecuado dependa de sus "actos del cargo" o el "cumplimiento de sus deberes"; por lo mismo, su incumplimiento no configura una venta de la voluntad estatal ni una desviación de funciones, aunque si una grave deslealtad política e infracción a deberes de probidad. Adicionalmente, del análisis del bien jurídico, se ha podido concluir que no cualquier deber/función se encuentra protegida por estos tipos penales, sino sólo aquellas que crean expectativas de relación entre el Estado y los ciudadanos en su relación con el primero. Aquello, obliga a determinar y limitar aún más el grupo de deberes abarcados penalmente.

La especificidad del tipo de deslealtad (infidelidad o traición) del parlamentario - no relacionada con o mandatada por la administración ni el Estado - exigiría una criminalización autónoma y orientada a un bien jurídico diferente y que se base en las expectativas reales de los ciudadanos en la formación de la voluntad general. Aquello sigue pendiente en nuestro país y debe ser solucionado.

\section{Conclusión}

Este artículo se ha propuesto como objetivo analizar si resulta posible utilizar el delito de cohecho como forma de solucionar los posibles vacíos de punibilidad pretéritas (anteriores a la Ley $\mathrm{N}^{\circ} 20.900$ ) y presentes en hipótesis de financiamiento irregular de la política. En particular se ha propuesto contestar las interrogantes sobre si a) ¿puede el parlamentario ser sujeto activo del delito de cohecho (arts. 248 y ss.)?; b) ¿puede el aporte económico para las campañas a cambio de una "tendencia favorable a los intereses del sector" ser abarcado bajo el "acto propio del cargo" o "acto en infracción de los deberes del cargo"? y c) ¿resulta punible el delito de cohecho activo sólo en la medida que se acredite un acuerdo ilícito (más allá de la discusión de la unilateralidad o bilateralidad del delito)?. Las conclusiones de este artículo pueden contestar esas interrogantes:

Los contornos fijados por el legislador, desde el punto de vista valorativo y formal, impiden que los tipos penales de cohecho (arts. 248 y ss.) puedan solucionar los posibles vacíos de punibilidad en hipótesis de financiamiento irregular de la política y, específicamente, en casos en que la contribución financiera no tenga como contraprestación un "acto político o legislativo concreto", sino una mera "actitud favorable a los intereses del sector". El modelo del "acuerdo ilícito" que desvalora el cohecho, por ofrecer o inducir a aceptar una actuación funcionarial desleal al mandato estatal en contra del interés que debe resguardar el titular del cargo, encuentra expresiones normativas concretas, que impiden la comprensión típica de las constelaciones de financiamiento irregular o ilegal de la política. Valorativamente esto se manifiesta en requisitos como a) un ámbito de la administración del Estado, cuya funcionalidad dependa del cumplimiento de deberes del funcionario público de representación o de ejecución de políticas; b) un funcionario titular de aquél deber mandatado por el Estado para representar su voluntad (representación o ejecución de políticas) que comercialice esa representación de voluntad estatal (omitir un acto del cargo; desviar el acto del cargo, exigir más derechos o cometer un delito); c) Un particular que incentive [o que acepte el ofrecimiento del funcionario de] celebrar un 
acuerdo bilateral más o menos sinalagmático, que tenga por objetivo modificar, en favor del particular, el mandato del funcionario de resguardar el interés o de representar la voluntad del Estado a cambio de una promesa económica. Incluso la propuesta discutida por el legislador en la actualidad, sobre la inclusión del cohecho en razón del cargo, también exigiría una manifestación objetiva de aquél acuerdo ilícito.

Si bien es posible encontrar ámbitos en que titulares de cargos públicos obtenidos por elección popular, como alcaldes o parlamentarios, pueden cumplir dichos requisitos valorativos- por ejercer funciones administrativas en que deben representar la voluntad estatal y susceptible de desviación -, aquello no sucede en las hipótesis de financiamiento político que este trabajo se ha propuesto analizar. Esto, porque las decisiones propias de las funciones políticas y legislativas - las intervenciones durante la discusión en comisiones, las negociaciones y el voto en un proyecto de ley [piénsese en un parlamentario que condiciona su voto a cambio de una política en favor de su región]- no constituyen cumplimiento de deberes del que dependa la funcionalidad de ámbito de la administración del Estado ni dicho acto político es consecuencia del mandato estatal de representación de su voluntad, sino de un mandato popular. De ahí, que el requisito de modificar la voluntad del Estado (interés estatal) - cristalizado en una concreta omisión de un acto del cargo, una desviación del acto del cargo o la exigencia de más derechos de los que por ley pueden ser exigidos (incluso la coaptación completa) - a cambio de un beneficio económico, no pueda ser verificable en las hipótesis estudiadas. Primero, porque fenomenológicamente, las hipótesis de financiamiento irregular se caracterizan porque el financista no espera como contraprestación de los parlamentarios un "acto legislativo concreto" (exigencia del modelo y de los tipos penales del art. 248 y ss.), sino solamente una "actitud favorable a los intereses de su sector" y; segundo, porque por definición el acto político y legislativo no puede calificarse como "infracción a deberes", ni desviación de funciones, ni pueden regirse materialmente por políticas de gestión pública dictadas por otras autoridades superiores. Incluso, si este delito pudiera ser calificado como infracción al deber o como un mero cohecho de facilitación (tipo de recogida), este no representaría aquél deber que expresa el mandato estatal sobre el cual esté diseñada la funcionalidad de un ámbito de la administración estatal. Aquel tipo de normas de probidad en el parlamento están destinadas a proteger la democracia y la correcta formación de la voluntad general, pero no la concreta administración del Estado (incluso en sentido amplio) encargada a sus agentes.

De lege ferenda, una adecuada captura penal de este tipo de hipótesis tendientes a proteger aquellos importantes aspectos de la democracia y la correcta formación de la voluntad general, pero que valore positivamente la actividad política y no pretenda someter las negociaciones políticas a una sospecha permanente de ilegalidad, debería optar por una criminalización autónoma y concreta o un perfeccionamiento de la legislación electoral. 


\section{Bibliografía}

AMELUNG, Knut, Rechtsgüterschutz und Schutz der Gesellschaft, Athenäum Verlag GmbH, Frankfurt a. M., 1972.

ARANCIBIA, Jaime "Concepto de Empleado Público Administrativo en el art. 260 del Código Penal”, en: Arancibia, Jaime/Martínez, José I. (Coord.), La Primacía de la Persona, Estudios en Homenaje al Profesor Eduardo Soto Kloss, LegalPublishing, 2009, pp. 961 - 971.

ARTAZA, Osvaldo, "La utilidad del concepto de corrupción de cara a la delimitación de la conducta típica en el delito de cohecho", Polít. crim. Vol. 11, No 21 (Julio 2016), Art. 11, pp. 307- 339.

BANNENBERG, Britta, Korruption in Deutschland und ihre strafrechtliche Kontrolle, Bundeskriminalamt (BKA) Kriminalistisches Institut, Hermann Luchterhand Verlag GmbH, 2002.

BULlEMORE, Vivian R. y MACKINNON, John R., Curso de Derecho Penal, Tomo IV, parte especial, Legal Publishing, Santiago, 2007.

BALMACEDA H., Gustavo, Los Delitos Funcionariales, en la Jurisprudencia, LegalPublishing-Thomson Reuters, Santiago, 2013.

BUNSTER BRICEÑO, Álvaro La malversación de caudales públicos: Estudio de Doctrina y Jurisprudencia, Santiago de Chile: Universidad de Chile (Memoria de Licenciatura en Ciencias Jurídicas y Sociales), 1948.

CONTRERAS ALFARO, Luis Humberto, "Sobre algunos aspectos penales de la corrupción de funcionarios públicos: La iniciativa del funcionario en el cohecho pasivo", en: Revista de Derecho, Consejo de Defensa del Estado, Año 2 - No 1 (agosto 2001), pp. 169-181.

DE LA MATA BARRANCO, Norberto, "El bien jurídico protegido en el delito de cohecho. La necesidad de definir el interés merecedor y necesitado de tutela en cada una de las conductas típicas encuadradas en lo que se conoce, demasiado genéricamente, como ámbito de la corrupción, en: Revista de Derecho Penal y Criminología, 2.a Época, $\mathrm{N}^{\circ} 17$ (2006), pp. 81-152.

DE LA MATA BARRANCO, Norberto, ¿Qué interés lesionan las conductas de corrupción?, en: EGUZKILORE, Número 23. San Sebastián, Diciembre 2009, pp. 245-259.

DÖLLING, Dieter, "Die Neuregelung der Strafvorschriften gegen Korruption", en: Zeitschrift für die gesamte Strafrechtswissentschaft, Bd 112, Cuaderno 2, 2000, pp. 334-355.

ETCHEBERRY, Alfredo, Derecho penal. Parte Especial, $3^{\circ}$ edición, Editorial Jurídica de Chile, Santiago 1998, T. IV.

FERNANDEZ, Pedro Javier, Código Penal de la República de Chile, esplicado y concordado, $2^{\text {a }}$ Edición, Tomo I, 1899.

FRANCUSKI, Ramona, "Die Neuregelung der Abgeordnetenbestechung ( $\S 108 \mathrm{e}$ StGB)", en: HRRS (Onlinezeitschrift für Höchstrichterliche Rechtsprechung zum Strafrecht), Julio, 2014. http://www.hrr-strafrecht.de/hrr/archiv/14-06/?sz=8 [Visitado el 02.02.2018].

GARCIA PALOMINOS, Gonzalo, "Del paradigma de la dañosidad social centrado en la infracción normativa al paradigma metodológico centrado en la norma de sanción: un falso dilema", en: BLANCO, R.; IRURETA, P. (Eds.) Justicia, Derecho y Sociedad, Libro en Memoria de Maximiliano Prado D., Santiago: Ediciones Universidad Alberto Hurtado, 2014, pp. 143-196. 
GARCIA PALOMINOS, Gonzalo, "La idealización y la administrativización de la punibilidad del uso de Información Privilegiada: Un análisis de los discursos penales en la doctrina chilena", en: Polít. Crim, Santiago v. 10, n. 19, jul. 2015, pp. 119-158.

GARCIA PALOMINOS, Gonzalo, "Equivalentes funcionales en los delitos económicos. Una aproximación de solución ante la falta de lesividad material en delitos de presentación de información falsa al mercado de valores", en: Polít. crim. Vol. 12, No 23 (Julio 2017), Art. 6, pp. 177-206.

GREEN, Stuart, Mentir; hacer trampas y apropiarse de lo ajeno, Una teoría moral de los delitos de cuello blanco, Madrid, Barcelona, Buenos Aires, Sao Paulo: Marcial Pons, 2013.

GRIBL, Kurt, Der Vorteilsbegriff bei den Bestechungsdelikten, C. F. Müller, Heidelberg, 1993.

GUZMÁN DALBORA, José L., "Esencia y Clase de Cohecho político", en: Cuadernos de Política Criminal, Número 106, I, Época II, abril 2012, pp. 223-250.

HEFENDEHL, Roland, Kollektive Rechtsgüter im Strafrecht, Köln: Carl Heymanns Verlag KG, 2002.

HEINE, Günter, "§ 331 ff. StGB”, en: SCHÖNKE/SCHRÖDER, Strafgesetzbuch, Edición 27., Editorial C. H. Beck, München, 2006.

HERNANDEZ, Héctor, "La inconveniente exigencia de un acto funcionario determinado como contraprestación en el delito de cohecho", en: Revista de Ciencias Penales, Sexta época, Vol. XLIII, N 4, 2016, pp. 15-27.

JAKOBS, Günther, Strafrecht, Allgemeiner Teil: Die Grundlagen und die Zurechnungslehre, De Gruyter Verlag, 1993.

JESCHECK, Hans-Heinrich, "Vorbemerkungen zu §331 StGB", en: Leipziger Kommentar, Editorial Walter de Gruyter, Edición 11. Aufl., Berlín, 1996, nm. 4.

KARGL, Walter, "Über die Bekämpfung des Anscheins der Kriminalität bei der Vorteilsannahme (\$331 StGB)", en: Zeitschrift für die gesamte Strafrechtswissentschaft, Bd. 114, 2002, pp. 763-793.

KARGL, Walter, "Parteispendenakquisition und Vorteilsannahme", en: Juristenzeitung (JZ), $\mathrm{N}^{\circ} 10$ (2005), pp. 503-512.

KORTE, Matthias, "Kommentar $\S \S 331$ StGB”, en: Münchener Kommentar, Strafgesetzbuch, Bd. 4, C. H. Beck, München, 2006.

LABATUT, Gustavo, Derecho Penal, Tomo III, $7^{\text {a }}$ Ed., Editorial Jurídica de Chile, 1992, Santiago.

LOOS, Fritz, "Zum Rechtsgut der Bestechungsdelikte", en: STRATENWERTH, Günter; KAUFMANN; Armin; GEILEN, Gerd; HIRSCH, Hans J., SCHREIBER, Hans-Ludwig; JAKOBS, Günther y LOOS, Fritz (Eds.), Festschrift für Hanz Welzel, Berlin, New York: Editorial Walter de Gruyer, 1974, pp. 879-895.

LOOS, Fritz, "Del 'bien jurídico' en los delitos de cohecho", en: Zeitschrift für Internationale Strafrechtsdogmatik (ZIS), 5/2009, pp. 266-269.

MATUS, Jean Pierre; RAMÍREZ, María Cecilia, Lecciones de derecho penal chileno. Parte especial, tomo II, Santiago: Editorial Jurídica de Chile, $3^{\text {a }}$ ed., 2015.

MAÑALICH, Juan Pablo, "La negociación incompatible como delito de corrupción: estructura típica y criterios de imputación”, en: REJ - Revista de Estudios de la Justicia - No 23 - Año 2015, pp. 93-105. 
MILITELLO, Vicenzo, "Concusión y cohecho de los funcionarios públicos", en: Terradillos Basoco, Juan M./ Acale, María, Temas de Derecho Penal Económico, Editorial Trotta, 2004, pp. 241-266.

MITSCH, Wolfgang, "Das Unternehmensdelikt", Juristische Ausbildung (JURA), Vol. 34 (7), 2002, pp. 526-530.

MÖHRENSCHALAGER, Manfred, "8. Kapitel. Der strafrechtliche Schutz gegen Korruptionen" en: DÖLLING, Handbuch der Korruptionsprävention für Wirtschaftsunternehmen und öffentliche Verwaltung, Verlag C.H. Beck München 2007, pp. 387.

MORALES, Baltazar, "El mérito, oportunidad y conveniencia en la Contraloría General de la República", en: Contraloría General de la República 85 años de vida institucional (1927-2012), pp. 207-220.

NAVARRO CARDOSO, Fernando, "Cohecho pasivo subsiguiente o por recompensa", en: Revista Electrónica de Ciencia Penal y Criminología (RECPC), 18-25 (2016), pp. 1-40.

NIEHAUS, Holger, "Zur Korruptionsstrafbarkeit kommunaler Mandatsträger Zugleich Anmerkung zur Entscheidung des BGH vom 9.5.2006 - 5 StR 453/05”, en: Zeitschrift für Internationale Strafrechtsdogmatik (ZIS), pp. 49-56. http://www.zis-online.com/dat/artikel/2008_1_204.pdf[Visitado el 02.02.2018].

NIETO GARCÍA, Alejandro, Corrupción en la España democrática, Ariel, Barcelona, 1997.

NIETO, Adán, "El concepto de funcionario público (art. 1)”, NIETO, Adán /ARROYO, Luis (Coord.), Fraude y Corrupción en el Derecho Penal económico Europeo, Colección Marino Barbero Santos, Ediciones Castilla de la Mancha, 2006, pp. 89-102.

NINO, Carlos, Un país al margen de la ley, $1^{\circ}$ edición, Ariel, Buenos Aires, 2005.

KINDHÄUSER, Urs, "Presupuestos de la corrupción punible en el Estado, la economía y la sociedad. Los delitos de corrupción en el Código penal alemán". Polít. crim. $\mathrm{n}^{\mathrm{o}}$ 3, 2007, A1, pp.1-18 [http://www.politicacriminal.cl]

OLIVER, Guillermo, "Aproximación al delito de cohecho", en: Revista de Estudios de la Justicia, № 5 - Año 2004, pp. 83-115.

OLIVER, Guillermo, "Incoherencia y Vacíos en la regulación del delito de Cohecho", en: Revista de Doctrina y Jurisprudencia, $\mathrm{N}^{\circ} 9$, Año 3, Universidad de Los Andes (Chile), Thomson Reuters, año 2012, pp. 30-50.

OTTO, Harro, Grundkurs Strafrecht, Allgemeine Strafrechtslehre, 7. Aufl., Walter de Gruyter, Berlin, 2004, § 99.

PACHECO, Joaquín Francisco, El Código Penal. Concordado y Comentado., $2^{\mathrm{a}}$ Edición, V. II, Madrid, 1856.

POLITOFF, Sergio/ MATUS A., Jean P./ RAMÍREZ, María Cecilia Ramirez, Lecciones de Derecho Penal chileno. Parte Especial, Editorial Jurídica de Chile, Santiago, 2003.

RODRÍGUEZ COLLAO, José Luis; OSSANDÓN WIDOW, Magdalena, Delitos contra la función pública, Santiago: Editorial Jurídica de Chile, $2^{\mathrm{a}}$ ed., 2008.

RODRÍGUEZ COLLAO, José Luis, "Delimitación del concepto penal de corrupción", en: Revista de Derecho de la Pontificia Universidad Católica de Valparaíso, XXV (Valparaíso, Chile, 2004), pp. 339-359.

RUDOLPHI, Hans- Joachim/ STEIN, Ulrich, "Vorbemerkungen §331 StGB und Kommentar $\S \S 331$ ff. StGB“, en: Systematischer Kommertar zum Strafgesetzbuch, Bd. II, 58. Lfg., 6. Aufl., Luchterhand Verlag, September 2003, nm. 7 a. 
SAMSON, Erich, "§ 11", en: Rudolphi, Hans-Joachim/ Stein, Ulrich (Coord.), Systematischer Kommentar zum Strafgesetzbuch, 7. Ed., Febrero 2005, § 11, nm. 20 (en la primera edición de 1975, § 11.)

SCHRÖDER, Horst, "Das Rechtsgut der Bestechungsdelikte und Bestechlichkeit des Ermessensbeamten”, en:_Goltdammer's Archiv für Strafrecht (GA) 1961, pp. 269 y 298.

SCHWIEGER, Dirk, Der Vorteilsbegriff in den Bestechungsdelikten des StGB, Peter Lang Verlag, Bd. 25, Frankfurt a. M., 1996.

SATZGER, Helmut, "Bestechungsdelikte und Sponsoring", en: Zeitschrift für die gesamte Strafrechtswissentschaft, Bd. 115, Cuaderno 4, 2003, pp. 469-500.

SCHMIDHÄUSER, Eberhard, Strafrecht, Besonderer Teil, § 24, J. C. B. Mohr Verlag, Tübingen, 1983, Edición 2.

SCHÜNEMANN, Bernd, "Die Unrechtsvereinbarung als Kern der Bestechungsdelikte nach dem KorrBekG", en: DANNECKER, Gerhard (Coord.) Festschrift für Harro Otto, Köln, München, 2007, pp. 777-798.

SILVA BASCUÑÁN, Alejandro, Tratado de Derecho Constitucional, T. II, Edit. Jurídica, Santiago, 2000.

TRÖNDLE, Herbert/ FISCHER, Thomas, "Vorbemerkungen zu § 331 und Kommentar $\S \S 331$ ff. StGB”, en: Tröndle/Fischer, Strafgesetzbuch und Nebengesetze, C. H. Beck, 54 Ed., München, 2007.

TORRES F., Angélica, "Los tipos penales creados por la ley №20.900 para el fortalecimiento de la democracia. Ofrecimiento, otorgamiento, solicitud y obtención indebida de aportes electorales; destinación indebida de aportes electorales estatales; entrega de antecedentes o certificación de hechos falsos al servicio electoral”, en: Revista jurídica del Ministerio Público, Nº68. Dic. 2016, pp. 25-56.

VAZQUEZ-PORTOMEÑE, Fernando, Los Delitos contra la Administración Pública, Ed. Universidad Santiago de Compostela, Instituto Nacional de Administración Pública, Madrid, 2003.

VAZQUEZ-PORTOMEÑE, Fernando, 'Sobre el cohecho por 'actos propios del cargo' y sus relaciones con el delito de exacciones ilegales", en: Cuadernos de Política Criminal, Número 116, II, Época II, sep. 2015, pp. 121-157.

VAZQUEZ-PORTOMEÑE, Fernando, "El delito de admisión de beneficios en consideración al cargo y la prevención de la corrupción pública en Bolivia", en: Rev. boliv. de derecho, $\mathrm{N}^{\mathrm{o}} 22$, julio 2016, ISSN: 2070-8157, pp. 120-142.

VAN DER HULST, Marc, El mandato parlamentario, un estudio comparado, Unión Interparlamentaria, Ginebra, Suiza, 2000.

VAHLENKAMP, Werner/ KNAUSS, Ina, Korruption - hinnehmen oder handeln?, Bundeskriminalamt, Forschungsreie, 1995.

WELZEL, Hans, "Studien zum System des Strafrechts", en: Zeitschrift für die gesamte Strafrechtswissentschaft, 1939, pp. 491-556.

WELZEL, Hans, Das Deutsche Strafrecht, Berlin: Walter de Gruyter Verlag, 11. Ed., 1969. 